\title{
Reconnaissance of the \\ Hydrothermal Resources of Utah
}

By F, EUGENE RUSH

GEOHYDROLOGY OF GEOTHERMAL SYSTEMS

GEOLOGICAL SURVEY PROFESIONAL PAPER $1044-\mathrm{H}$

A brief description of the hydrothermal resources of Utah 


\section{DISCLAIMER}

This report was prepared as an account of work sponsored by an agency of the United States Government. Neither the United States Government nor any agency Thereof, nor any of their employees, makes any warranty, express or implied, or assumes any legal liability or responsibility for the accuracy, completeness, or usefulness of any information, apparatus, product, or process disclosed, or represents that its use would not infringe privately owned rights. Reference herein to any specific commercial product, process, or service by trade name, trademark, manufacturer, or otherwise does not necessarily constitute or imply its endorsement, recommendation, or favoring by the United States Government or any agency thereof. The views and opinions of authors expressed herein do not necessarily state or reflect those of the United States Government or any agency thereof. 


\section{DISCLAIMER}

Portions of this document may be illegible in electronic image products. Images are produced from the best available original document. 


\section{UNITED STATES DEPARTMENT OF THE INTERIOR JAMES G. WATT, Secretary}

\section{GEOLOGICAL SURVEY}

Dallas L. Peck, Director

\section{Library of Congress Cataloging in Publication Data}

Rush, F. Eugene

Reconnaissance of the hydrothermal resources of Utah.

(Geological Survey Professional Paper 1044-H)

Bibliography

Supt. of Docs. no.: I 19.16: 1044-H

1. Geothermal resources-Utah. I. Title. II. Series: United States. Geological Survey. Professional Paper 1044-H.

GB1199.7.U8R87

553.7

$82-600009$

AACR2

For sale by the Superintendent of Documents, U.S. Government Printing Office Washington, D.C. 20402 


\section{CONTENTS}

Abstract

Introduction

Purpose and scope

Previous work

Well- and spring-numbering system

Regional geologic setting

Middle Rocky Mountains

Colorado Plateaus

Basin and Range

Regional hydrologic setting

Geothermal relations

Relation of thermal waters to hydrogeologic framework

Distribution of thermal waters

Page
H1
$-\quad 1$
$-\quad 1$
$-\quad 1$
$-\quad 1$
$-\quad 3$
$-\quad 3$
$-\quad 3$
$-\quad 3$
$-\quad 4$
$-\quad 5$
$-\quad 5$
$-\quad 6$
$-\quad 7$

Discussion of prospects Roosevelt Hot Springs and the Cove Fort-Sulphurdale areas

Thermo Hot Springs _...

Southwestern Escalante Desert _... 18

Monroe and Joseph KGRA

Crater Hot Springs _...... 28

Navajo Lake KGRA _... 33

Meadow and Hatton Hot Springs _._. 33

Vicinity of Salt Lake City ___._. 37

Great Salt Lake Desert _._. 39

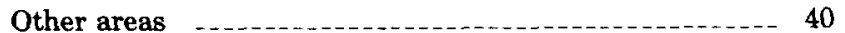

Summary and conclusions

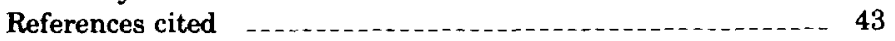

\section{ILLUSTRATIONS}

FIGURE 1. Map showing land prospectively valuable for geothermal resources in Utah and index map of Utah

2. Diagram showing location-numbering system _...

3. Map showing generalized east-west patterns of Cenozoic igneous rocks and positive aeromagnetic anomalies and a generalized distribution of young igneous rocks . .

4. Diagram showing a conceptual model of a hydrothermal convection cell

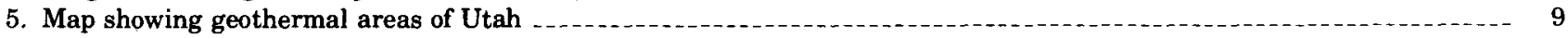

6. Map showing location of leased National Resource Land in Utah, September 1976

7. Reconnaissance geologic map of the Thermo Hot Springs area and audio-magnetotelluric configuration for the Thermo Hot

Springs area

8.-11. Map showing

8. Distribution of orifices at Thermo Hot Springs

9. Temperature at a depth of $30 \mathrm{~m}$ in the Thermo Hot Springs area and distribution of vegetation in the Thermo Hot Springs area, 1976

10. Shallow conductive heat flow in the Thermo Hot Springs area

11. Estimate heat flow in southwestern Utah _... 20

12. Reconnaissance geologic map of the Newcastle area; and ground-water levels and direction of flow in the alluvium of the Newcastle area, spring 1976

13. Graph showing temperature profile of the Christensen Brothers thermal irrigation well near Newcastle, Utah

14.-17. Map showing

14. Temperatures at a depth of $100 \mathrm{~m}$ in the Newcastle area

15. Distribution of heat-flow from the principal hot-water aquifer in the Newcastle area

16. Helium concentrations in the Newcastle area

17. Estimated heat flow and measured spring temperatures in the Monroe-Joseph area

18. Surficial geology of Monroe and Red Hill Hot Springs

19. Map showing Thomas, Keg, and Desert calderas, near Crater Hot Springs

20. Reconnaissance geologic map of the Crater Hot Springs area and a simple Bouguer gravity map of the Crater Hot Springs area 32

21. Generalized cross section of Crater Bench

22. Map showing spring orifices and pools on the mound of Crater Hot Springs

23. Map showing phreatophyte distribution in the Crater Hot Springs area

24. Map showing heat flow in the Crater Hot Springs area

25. Reconnaissance geologic map of the Meadow and Hatton Hot Springs area

26. Map showing estimated heat flow and water temperatures in the Meadow and Hatton Hot Springs area

27. Map showing areas of rapid snowmelt near Hatton Hot Springs, March 1976

28. Map showing areas of warm ground water in the Jordan Valley 


\section{TABLES}

1. Relation of hydrothermal areas to mineral belts and to age of Cenozoic igneous rocks

2. Thermal-conductivity values used in this report

3. Formulas for geothermometers used in this report

4. Known geothermal resource areas in Utah _........ 8

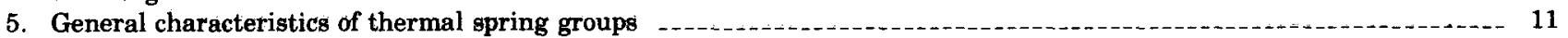

6. Estimated reservoir temperatures derived by geothermometer formulas for springs (and one well) with temperatures greater than $50^{\circ} \mathrm{C}$ and silica concentration greater than $50 \mathrm{mg} / \mathrm{L}$

7. Evapotranspiration of mixed water from Thermo Hot Springs hydrothermal system

8. Estimated conductive heat discharge from Thermo Hot Springs hydrothermal system-alluvial area only _......... 19

9. Chemical analyses of water from Christensen Brothers thermal well near Newcastle, Utah

10. Estimated conductive heat discharge from the Newcastle hydrothermal system-alluvial area only

11. Measured flow and temperature of Monroe and Red Hill Hot Springs

12. Measured flow and temperature of Joseph Hot Springs

13. Measured flow and temperature of Crater Hot Springs

14. Evapotranspiration of ground water from Crater Hot Springs hydrothermal system

15. Summary of data for selected hydrothermal systems in Utah

16. Inventory of Thermo Hot Springs 46

17. Inventory of Crater Hot Springs, February 1976

18. Selected subsurface temperature and heat-flow data not summarized on maps

\section{CONVERSION OF UNITS}

For use of those readers who may prefer to use inch-pound units rather than metric units, the conversion factors for the terms used in this report are listed below:

$\begin{array}{lc}\text { Multiply metric unit } & B y \\ \text { calories (cal) } & 3.974 \times 10^{-3} \\ \text { degrees Celsius }\left({ }^{\circ} \mathrm{C}\right) & 1.8^{\circ} \mathrm{C}+32 \\ \text { milligrams }(\mathrm{mg}) & 1.543 \times 10^{-2} \\ \text { kilograms }(\mathrm{kg}) & 2.205 \\ \text { liters }(\mathrm{L}) & .2642 \\ \text { meters }(\mathrm{m}) & 3.281 \\ \text { millimeters }(\mathrm{mm}) & 3.937 \times 10^{-2} \\ \text { centimeters }(\mathrm{cm}) & .3937 \\ \text { hectometers }(\mathrm{hm}) & 3.281 \times 10^{-2} \\ \text { kilometers }(\mathrm{km}) & .6214 \\ \text { square centimeters }\left(\mathrm{cm}^{2}\right) & .1550 \\ \text { square kilometers }\left(\mathrm{km}^{2}\right) & .3861 \\ \text { cubic meters }\left(\mathrm{m}^{3}\right) & 35.31 \\ \text { liters per second }(\mathrm{L} / \mathrm{s}) & 15.85\end{array}$

\author{
To obtain inch-pound unit \\ British thermal units (B.t.u.) \\ degrees Fahrenheit $\left({ }^{\circ} \mathbf{F}\right)$ \\ grains \\ pounds (lb) \\ gallons (gal) \\ feet $(\mathrm{ft})$ \\ inches (in) \\ inches (in) \\ feet $(\mathrm{ft})$ \\ miles (mi) \\ square inches $\left(\mathrm{in}^{2}\right)$ \\ square miles $\left(\mathrm{mi}^{2}\right)$ \\ cubic feet $\left(\mathrm{ft}^{3}\right)$ \\ gallons per minute (gal/m)
}




\title{
GEOHYDROLOGY OF GEOTHERMAL SYSTEMS
}

\section{RECONNAISSANGE OF THE HYDROTHERMAL RESOURCES OF UTAH}

\author{
By F. EUGENE Rush
}

\section{ABSTRACT}

Geologic factors in the Basin and Range province in Utah are more favorable for the occurrence of geothermal resources than in other areas on the Colorado Plateaus or in the Middle Rocky Mountains. These geologic factors are principally crustal extension and crustal thinning during the last 17 million years. Basalts as young as 10,000 years have been mapped in the area. High-silica volcanic and intrusive rocks of Quaternary age can be used to locate hydrothermal convection systems. Drilling for hot, high-silica, buried rock bodies is most promising in the areas of recent volcanic activity. Southwestern Utah has more geothermal potential than other parts of the Basin and Range province in Utah. The Roosevelt Hot Springs area, the Cove Fort-Sulphurdale area, and the area to the north as far as 60 kilometers from them probably have the best potential for geothermal development for generation of electricity. Other areas with estimated reservoir temperatures greater than $150^{\circ} \mathrm{C}$ are Thermo, Monroe, Red Hill (in the Monroe-Joseph Known Geothermal Resource Area), Joseph Hot Springs, and the Newcastle area. The rates of heat and water discharge are high at Crater, Meadow, and Hatton Hot Springs, but estimated reservoir temperatures there are less than $150^{\circ} \mathrm{C}$. Additional exploration is needed to define the potential in three additional areas in the Escalante Desert.

\section{INTRODUCTION}

\section{PURPOSE AND SCOPE}

The State of Utah has an abundance of thermal springs and probably is a promising area for geothermal exploration. This study, a 2-year reconnaissance of the geothermal resources on the public lands of Utah, was begun by the U.S. Geological Survey in the summer of 1975. The purpose of the reconnaissance was to describe the general geohydrologic framework for geothermal systems, and to provide more detailed descriptions and evaluations than were previously available for some of the more promising hydrothermal systems. Most of the data were gathered and evaluated during the summer of 1975 and in 1976. This report presents the results of the study. A data report (Rush, 1977) has already been released which contains subsurface-temperature data for 30 wells.

\section{PREVIOUS WORK}

The earliest known reference to geothermal systems of Utah is by Gilbert (1890, p. 332-335); he briefly described Fumarole Butte, gaseous discharges from the butte, and nearby Crater Hot Springs (fig. 1). Many years later Stearns, Stearns, and Waring (1937, p. 96, $108-109,179-183$ ) described about 60 thermal springs in Utah and summarized the literature about them. A similar summary was made by Waring (1965). At the East Tintic mining district, about $30 \mathrm{~km}$ northwest of Nephi (fig. 1), Lovering and Goode (1963) worked with geothermal gradient holes in their search for hydrothermal ore bodies. In another mining area, the Iron Springs district about $16 \mathrm{~km}$ west of Cedar City, (fig. 1), Sass and others (1971, p. 6399-6400) described temperature measurements in eight drill holes. They concluded that the heat flow in that area is about $1.9 \times 10^{6}$ $\mathrm{cal} / \mathrm{cm}^{2} / \mathrm{s}$.

Heylmun (1966) and Batty and others (1975, p. 233241) presented brief, general discussions of geothermal resources in Utah. However, both papers presented few data. A comprehensive data report on the thermal springs of Utah (Mundorff, 1970) contains an abundance of information for about 60 springs. Additional data have been published by Milligan, Marselli, and Bagley (1966). Additional estimates of reservoir temperatures were made for $\mathbf{4 7}$ hydrothermal systems in Utah by Swanberg (1974), using the Na-K-Ca geothermometer developed by Fournier and Truesdell (1973).

Olmsted and others $(1975$, p. $27-76)$ provided a discussion of hydrothermal concepts and of exploration and evaluation techniques in a report describing hydrothermal systems in the western part of the Basin and Range province. This discussion was useful as a guide in the study and other workers probably will find it of similar value. The University of Utah, Department of Geology and Geophysics, is currently (1977) investigating Roosevelt Hot Springs KGRA (Known Geothermal Resource Area) and other areas, primarily evaluating various geophysical techniques for geothermal exploration. In one of the resulting reports, Parry, Berson, and Miller (1976) describe the geology and water chemistry of Roosevelt and Monroe Hot Springs.

\section{WELL- AND SPRING-NUMBERING SYSTEM}

The system of numbering wells and springs in Utah, used herein, is based on the cadastral land-survey system of the U.S. Government. The number describes the position on the land net of the well, spring, or site where geothermal observations were made. In the land-survey 
system, the State is divided into four quadrants by the Salt Lake base line and meridian, and these quadrants are designated by the uppercase letters $A, B, C$, and D, indicating the northeast, northwest, southwest, and southeast quadrants, respectively. Numbers designating the township and range (in that order) follow the quadrant letter, and all three are enclosed in parentheses. The number after the parentheses indicates the section, and the section commonly is followed by three letters indicating the quarter section, the quarterquarter section, and the quarter-quarter-quarter section (generally $\left.4 \mathrm{hm}^{2}\right)^{1}$; the letters $a, b, c$, and d indicate,

1The basic land unit, the section, is ideally $2.6 \mathrm{~km}^{2}$; however, many sections are irregular. Such sections are subdivided into $4 \mathrm{~km}^{2}$ tracts, generally beginning at the southeast corner, and the surplus or shortage is taken up in the tracts along the north and west sides of the section.

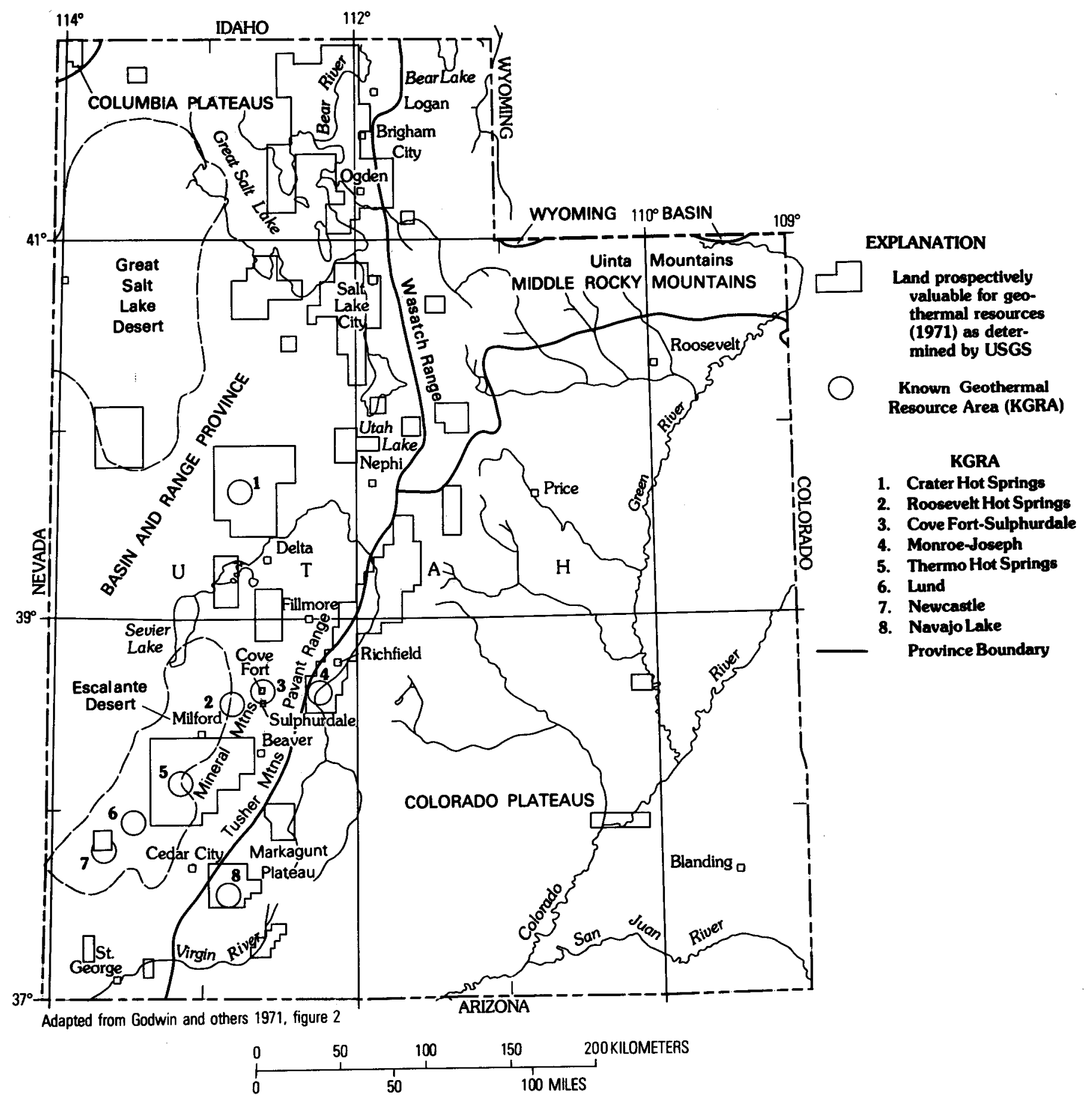

FIGURE 1.-Land prospectively valuable for geothermal resources in Utah, and an index map of Utah. 
respectively, the northeast, northwest, southwest, and southeast quarters of each subdivision. The number after the letters is the serial number of the well or spring within the $4 \mathrm{hm}^{2}$ tract; the letter " $\mathrm{S}$ " preceding the serial number denotes a spring. If a well or spring cannot be located within a $4 \mathrm{hm}^{2}$ tract, less than three location letters are used and the serial number is omitted. Thus (C-29-8)9ba designates a well in the $\mathrm{NW}^{1 / 4} \mathrm{NW}^{1 / 4}$ sec. 9 , T. 29 S., R. 8 W. The numbering system is illustrated in figure 2 .

\section{REGIONAL GEOLOGIC SETTING}

Utah essentially includes parts of three physiographic provinces as defined by Fenneman (1931): the Middle Rocky Mountains, the Colorado Plateaus, and the Basin and Range province (fig. 1). Each area is described briefly below, but more emphasis is given to the Basin and Range province because of its greater potential for geothermal development.

\section{MIDDLE ROCKY MOUNTAINS}

In Utah the Middle Rocky Mountains province includes the Wasatch Range and the Uinta Mountains. The Wasatch Range rises to an altitude of 2,400 to 3,400 $\mathrm{m}$ above sea level, or between 1,200 and $2,000 \mathrm{~m}$ above

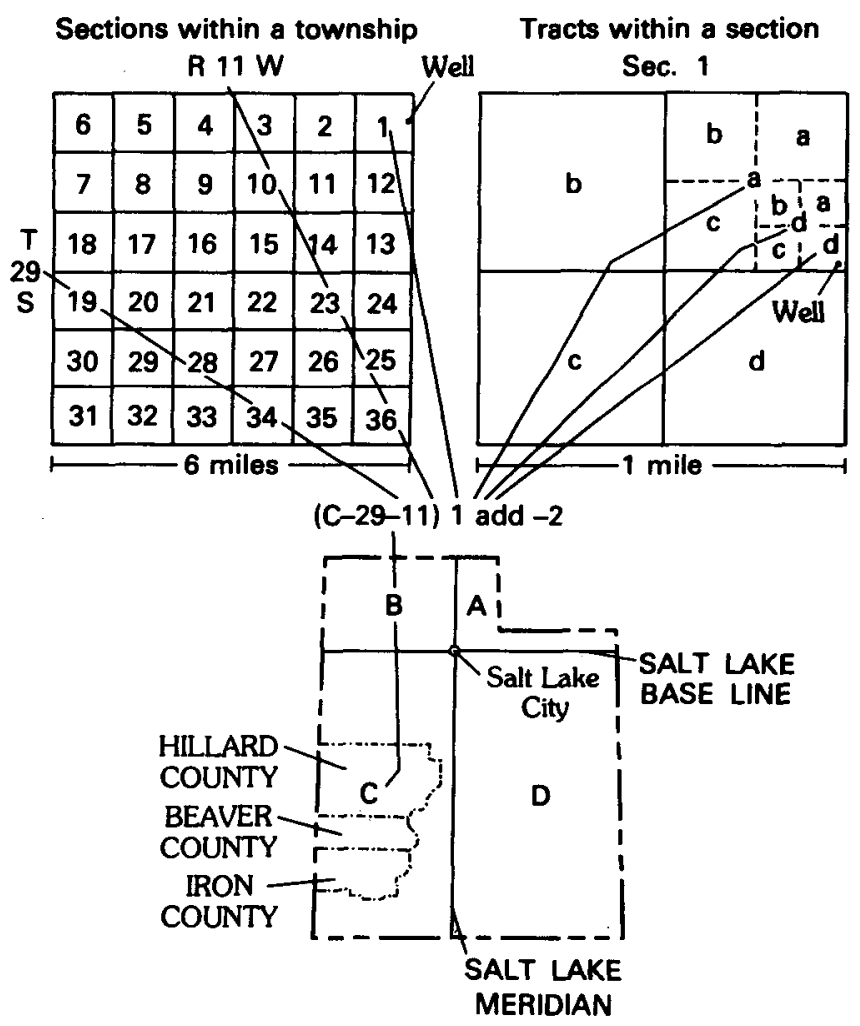

Figure 2.-Well- and spring-numbering system. the valley floors of the Basin and Range province. The range is an uplifted block of folded and faulted strata, bounded on the west by a major fault zone, the Wasatch Fault. The Uinta Mountains are generally higher than the Wasatch Range, reaching altitudes greater than 4,000 $\mathrm{m}$ above sea level. They are described by Fenneman $(1931$, p. 177) as a flat-topped anticline. Most of the consolidated rocks that crop out in both mountain ranges are pre-Cenozoic sedimentary or silicic plutonic rocks.

\section{COLORADO PLATEAUS}

The province, as implied by its name, is an area of broad uplift with strata nearly horizontal in most places. The outcrops are mostly Mesozoic and older sedimentary rocks. Notable exceptions are Tertiary and Quaternary volcanic rocks in the southwestern part of the province (south-central Utah) and a few scattered Tertiary intrusive bodies in the southeastern part of the state. Land-surface altitudes are commonly between 1,500 and $3,000 \mathrm{~m}$ above sea level. A continuation of the Wasatch Fault zone marks the western boundary of the province.

\section{BASIN AND RANGE}

The Basin and Range province is characterized by elongated, mostly north-trending mountain ranges and narrow flat-bottomed valleys. The province contains rocks widely ranging in composition and age. The older rocks consist of a wide variety of Mesozoic and Paleozoic sedimentary rocks and their metamorphosed equivalents. Overlying the sedimentary and metamorphic rocks are Cenozoic volcanic rocks and valley fill. Valley fill, mostly alluvium, may be as thick as $3,000 \mathrm{~m}$ in some basins. Lacustrine deposits are common.

According to Stewart (1971), most or perhaps all of the major valleys in the Great Basin of the Basin and Range province can be considered to be grabens, and most or all of the mountains can be considered to be horsts or tilted horsts. The geometry of block faulting related to these structures requires sizable east-west extension of the thin crust under the province; the extension was estimated by Stewart to be about $2.4 \mathrm{~km}$ for each major valley. Most of this extension took place in the last 17 million years, or perhaps even in the last 7-11 million years. In Utah, grabens which are not bounded by faults of equal displacement generally have the master fault on the east side.

In western Utah, igneous rocks and hydrothermal mineral zones are in well-defined east-west belts (fig. 3 ), each successively younger to the south (table 1), according to Stewart, Moore, and Zietz (1977). Figure 3 shows 
the distribution of igneous rocks less than 6 million years old; some are less than 10,000 years old. They are mostly basalt and crop out generally in southwestern Utah. These very young igneous rocks do not seem to be along an east-west belt but rather on an alinement parallel to Basin and Range structure. The implication is that Basin and Range structure controls the distribution of these rocks; whereas the older belts predate Basin and Range structure. Stewart, Moore, and Zietz (1977) see genetic and age similarity between these belts and the belt of upper Cenozoic volcanic rock extending along the Snake River Plain in southern Idaho eastward into the Yellowstone region of northwestern Wyoming.

Very young volcanic rocks in Utah are reported by Rowley, Anderson, and Williams (1975, p. B18), and Smith and Shaw (1975, p. 82). Volcanic rocks probably less than 10,000 years old are found near Fillmore and $65 \mathrm{~km}$ southwest, $50 \mathrm{~km}$ south, and $30 \mathrm{~km}$ southeast of Cedar City (fig. 3). These young rocks are largely basaltic, but scattered rhyolitic cones are known (Liese, 1957).

Silicic intrusive rocks were emplaced at the same time as the silicic volcanic rocks (Whelan, 1970). The

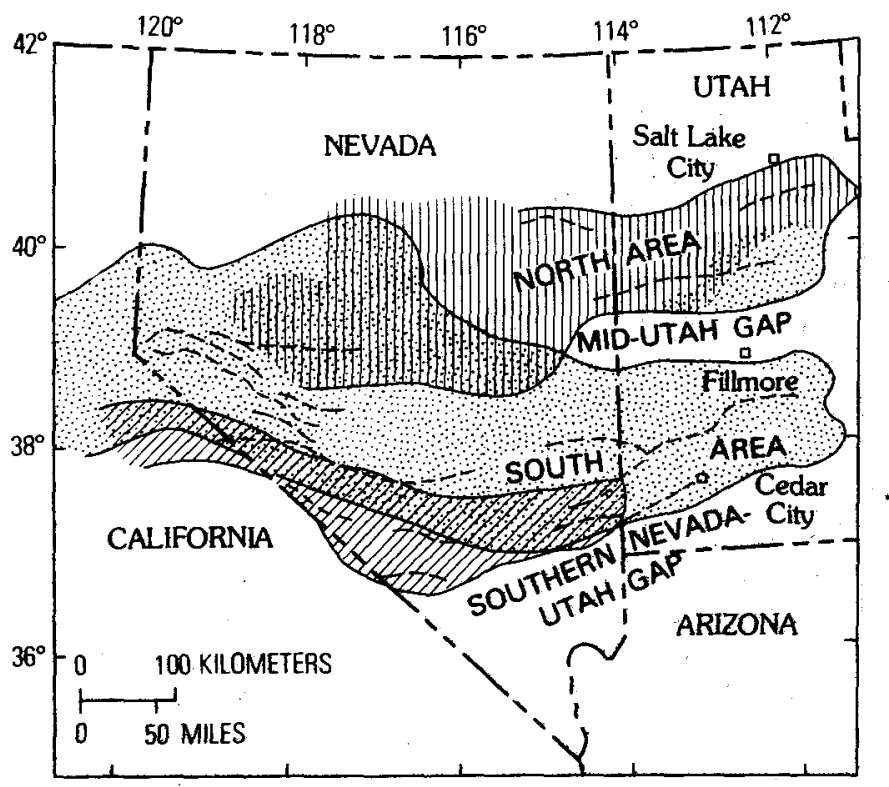

EXPLANATION

Generalized areas of outcrop of volcanic rocks within east-west belts

QIIT) 17-6 my. 34-17 m.y.

East-west trends of aeromagnetic anomalies related to Mesozoic and Tertiary rocks largest exposure of such an intrusive body in Utah is the Mineral Mountains, $80 \mathrm{~km}$ north of Cedar City.

\section{REGIONAL HYDROLOGIC SETTING}

Precipitation on the semiarid valley floors of the Basin and Range province in Utah, as well as much of the Colorado Plateaus, averages less than $200 \mathrm{~mm}$ per year (U.S. Weather Bureau, no date). The higher mountains of the Wasatch Range and the Uinta Mountains generally receive precipitation of $1,000 \mathrm{~mm}$ or more per year, most accumulating as snow in the winter. The mountains of the Basin and Range province average about $500 \mathrm{~mm}$ or less yearly.

The relatively large amounts of precipitation that fall in the mountains flow toward the ground-water reservoirs and major streams in two ways: (1) Flow from the mountains in small streams. Part of this water infiltrates the stream beds and percolates to the water table. (2) Flow percolates directly into the fractures and pore space of consolidated rocks of the mountains; this water then flows in the subsurface across the consolidated rock - valley-fill contact. The latter is considered to be the smaller volume of water in most areas; an exception is in areas of carbonate rocks that have developed interconnected solution channels. Most of the ground water

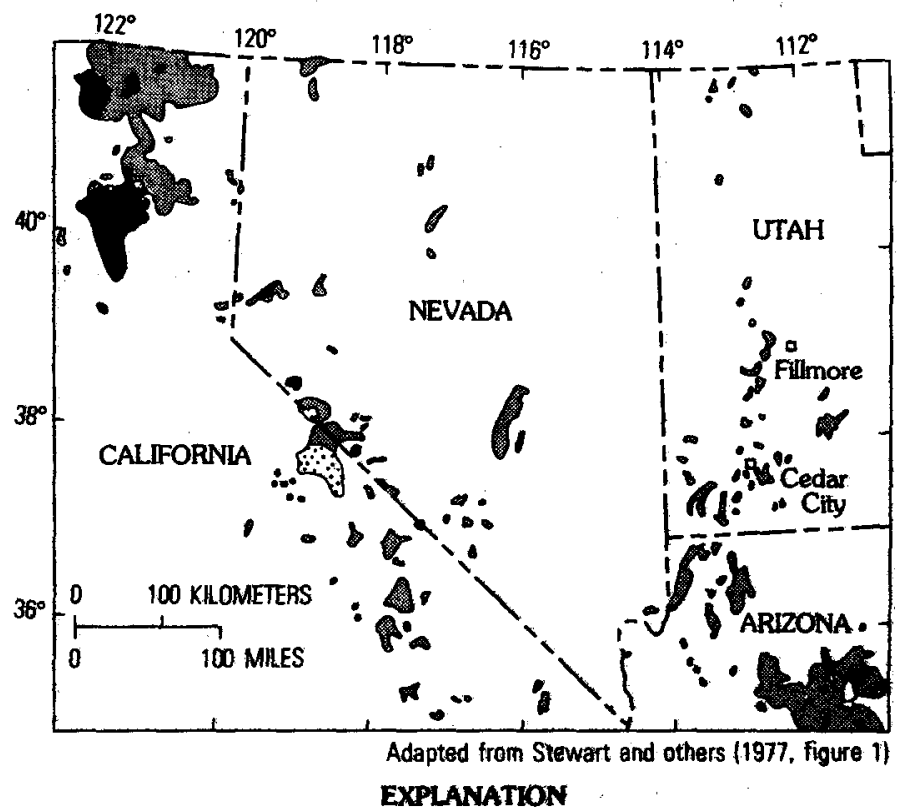

Basalitic flows Andesitic flows and breocias hntrusive rocks Rhyolitic tufts

FIGURE 3.-Generalized distribution of young and old igneous rocks. $A$, East-west patterns of Cenozoic igneous rocks and positive aeromagnetic anomalies show southward migration of igneous activity in California, Nevada, and Utah. $B$, Igneous rocks less than 6 million years old in western Utah, Nevada, and parts of adjoining states seem to parallel Basin and Range structure. 
TABLE 1.-Relation of hydrothermal areas to mineral belts and to age of Cenozoic igneous rocks [The areas of western Utah are as shown in figure 4. The areas and mineral belts are listed in order from north to south. The ages of the rocks are from Stewart and others (1977, p. 71)]

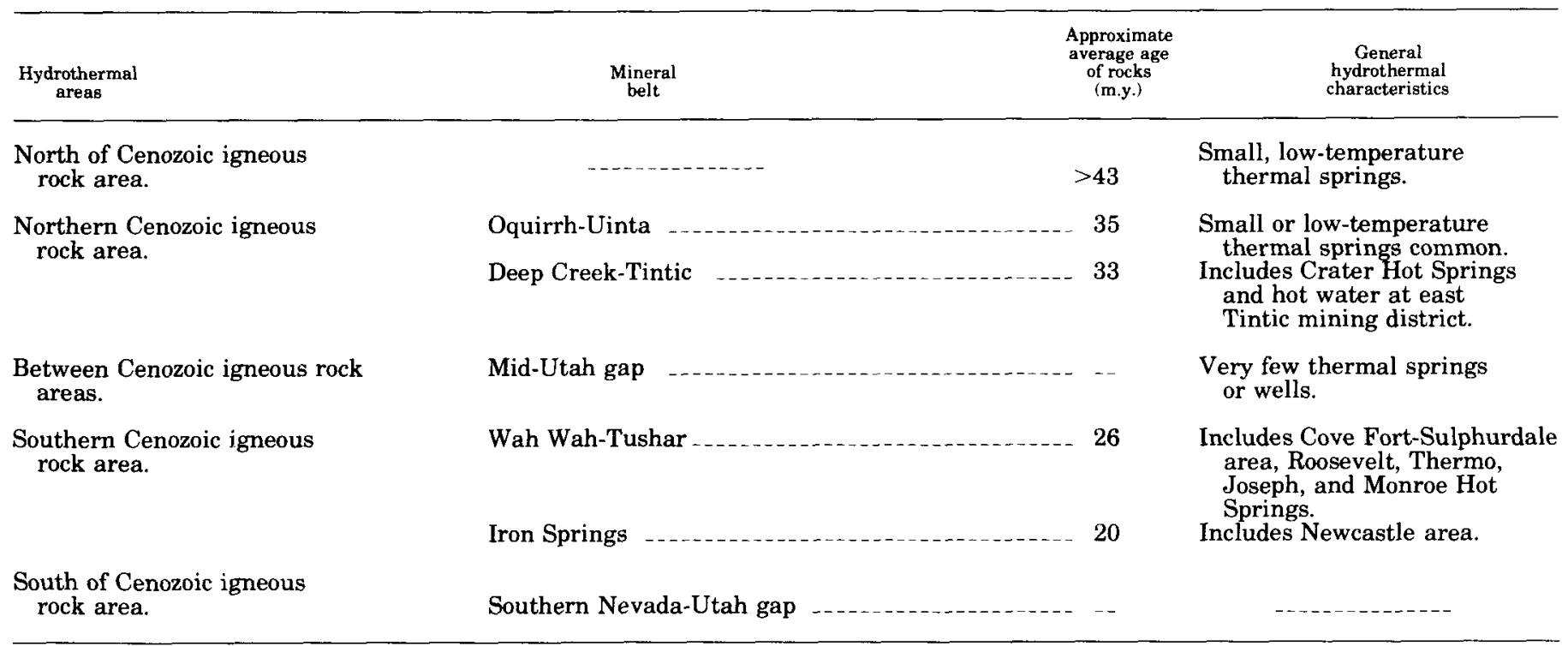

circulates to depths of only several tens to several hundred meters, and generally has a temperature near or slightly higher than the ambient land-surface temperature for the lowlands $\left(10^{\circ}-16^{\circ} \mathrm{C}\right)$. Some ground water migrates through fault-created fractures to great depth where it absorbs heat from wall rock. This heated water returns to the land surface along with the shallow-circulating ground water, where it is ultimately discharged as springs, to streams, by evapotranspiration, or from wells. In agricultural areas, a secondary source of ground-water recharge to the valley-fill reservoir is infiltration from fields, canals, and reservoirs. Summers are usually hot with low humidity. As a result, on lowlands, potential lake evaporation greatly exceeds precipitation.

Some of the valleys in the Basin and Range province are hydrologically isolated; that is, water that falls as precipitation remains within the basin until it is discharged back to the atmosphere. However, in areas where interconnected solution channels have developed, ground water may follow complex flow paths beneath interbasin divides and flow for tens or hundreds of kilometers and for thousands of years before discharging to the land surface. Commonly, this interbasin flow involves moderately deep circulation beneath mountain ranges and, as a result, its discharge is significantly above ambient temperature. A probable example of discharge from an interbasin regional flow system is the Fish Springs group (Mundorff, 1970, p. 37), about $90 \mathrm{~km}$ northwest of Delta on the south edge of the Great Salt Lake Desert. The estimated discharge is $1.4 \mathrm{~m}^{3} / \mathrm{s}$. Water temperatures reportedly range from $18^{\circ}$ to $76^{\circ} \mathrm{C}$. The recharge areas for these springs are probably to the south and west and probably include parts of Nevada.

The principal sources of geothermal fluids are water stored in the hydrothermal reservoir and water entering the geothermal-circulation system as recharge from precipitation. Because of the semiarid climate of much of the area, most geothermal development for generation of electricity will remove fluids from storage at a higher rate than natural replenishment.

\section{GEOTHERMAL RELATIONS}

\section{REGIONAL HEAT FLOW}

The average conductive heat flow to the earth's surface is approximately $1.6 \mathrm{HFU}$ (1 heat-flow unit [HFU] $=1 \times 10^{-6} \mathrm{cal} / \mathrm{cm}^{2} / \mathrm{s}$ or $1 \mu \mathrm{cal} / \mathrm{cm}^{2} / \mathrm{s}$, according to Schubert and Anderson, 1974). Considerable variation in flow exists in Utah. Based on data from Sass and others (1971) and Sass and Munroe (1974), the area of highest heat flow in Utah is the Basin and Range province, which has heat-flow values commonly in the range of 1.5 to 2.5 HFU. By comparison the "Battle Mountain High" (in Nevada) is an area of abnormally high heat flow where conductive heat-flow values are commonly in the range of 2.5 to $3.5 \mathrm{HFU}$. According to Lachenbruch and Sass (1977), the "Battle Mountain High" may 
be a part of a larger region of exceptionally high heat loss extending from western Nevada to Yellowstone Park, Wyo., and including the northwestern corner of Utah. No data were collected as part of this study to determine whether the northwestern corner of Utah is an area of very high heat flow. Data from this study, and the work of others, indicate that the Basin and Range province in Utah probably has an average heat flow of about 2 HFU.

The Colorado Plateaus and the Middle Rocky Mountains provinces in Utah have heat-flow values near the average for the earth's surface. Values published by Sass and others (1971) and by Sass and Munroe (1974) for these areas generally range from 1.3 to 2.0 HFU and average about 1.6 HFU.

The causes of variation in heat flow to the earth's surface are complex and poorly understood. Some of the factors that contribute to the diversity are (1) variations in crustal thickness, (2) convection of magma beneath and possibly within the lower parts of the crust, (3) movement of ground water in hydrothermal convection cells, (4) variations in the distribution of radioactive elements such as uranium, thorium, and potassium-40 in crustal rock, (5) intrusion into the upper crust of young magmas, and (6) general circulation of shallow ground water.

\section{RELATION OF THERMAL WATERS TO HYDROGEOLOGIC FRAMEWORK}

The present level of geothermal knowledge is in part presented by White and Williams (1975) and is briefly summarized as follows: (1) Some geothermal systems are supplied only by a "normal" geothermal gradient; some by magmatic heat. (2) Youngest igneous rocks have the best potential as heat sources. (3) Purely basic volcanic systems rarely form thermal anomalies of economic interest for generation of electricity, whereas silicic volcanic systems may do so if they are large enough. (4) Young basic volcanoes are produced by magma sources in the mantle and, under some conditions, are potential indicators of buried high-level silicic bodies with no obvious surface manifestations. (5) Silicic magmas are always erupted from high-level storage chambers, probably in the upper $10 \mathrm{~km}$ of the crust. (6) High-temperature convection systems can be sustained for many thousands of years with heat from high-silica magma bodies. Perhaps because of the very high viscosities of such magmas, these systems are associated with magma chambers at shallow levels in the crust. (7) Cooling by hydrothermal convection tends to offset continued heating, but the rate of supply of magma from deep crustal or mantle sources is the dominant heat supply for both high-level magmatic and hydrothermal systems. (8) Basic magmas rise through the crust to the surface through narrow pipes and fissures created by faulting; the individual magma pulses are volumetrically small, and such systems contribute little stored heat to the upper crust until magma chambers begin to form at high levels. (9) Fluid temperature is of critical importance in determining how a hydrothermal system may be utilized and is the most important single factor in evaluating a system. Hot-water convection systems can be divided into those of three temperature ranges: (a) Above $150^{\circ} \mathrm{C}$; these systems may be considered for generation of electricity; (b) from $90^{\circ} \mathrm{C}$ to $150^{\circ} \mathrm{C}$; these systems are attractive for space and process heating; and (c) below $90^{\circ} \mathrm{C}$; these systems are likely to be utilized for heat only in locally favorable circumstances. (10) Natural geysers and active deposition of siliceous sinter (amorphous hydrous silica) are reliable indicators of subsurface temperatures at least as high as $180^{\circ} \mathrm{C}$. On the other hand, travertine deposits (calcium carbonate) and opaline residues produced by sulfuric acid leaching have no reliable relation to reservoir temperature. (11) In the Basin and Range province, heat flows are sufficiently high that the existence of a thick blanket having low thermal conductivity (high-porosity clay beds, for example) could locally raise the temperatures to levels of economic interest. The above abbreviated summary can be used as a partial guide to the general relation of thermal waters to the hydrogeologic framework.

Most thermal springs and wells are in valleys near the margins of the mountains. Spring positions probably are controlled by Basin and Range faults. Some springs are in valley bottoms; others are on upland slopes. Only a few thermal springs are in a mountainous setting; the most prominent example is Midway Hot Springs, $45 \mathrm{~km}$ southeast of Salt Lake City (Mundorff, 1970 , p. 46).

Recharge to the hydrothermal systems is by either meteoric water in the nearby shallow, ground-water reservoir or by percolation in the nearby mountains. The dominant driving force for deep circulation probably is the difference in density between cold recharge water and hot upflowing water, but head differences between recharge area and springs may contribute as shown in figure 4.

The hot water rising from the hydrothermal reservoir may be greatly diluted by shallower-circulating cold water, lowering the temperature but increasing the flow of thermal springs above the hydrothermal reservoir. As shown in figure 4, only part of the upflow of thermal water may directly reach the land surface, because part may enter near-surface aquifers and cool by conduction as it flows laterally from the spring area.

The model described above may be modified in several ways to approximate the variety of hydrothermal systems: (1) No convecting magma may be present in the upper crust, but rather the heat source may be deeper in 
the crust or in the mantle; (2) the downward flow of cold water to the hydrothermal reservoir may be through any deep permeable route; and (3) calcium carbonate and amorphous silica may deposit on the walls of the upflow zone, creating an isolated or semi-isolated conduit or self-sealing cap. As a result, movement of water between the isolated part of the hydrothermal convection cell and the surrounding rock, alluvium, or land surface would be reduced or eliminated.

Vertical flow of shallow nonthermal ground water may modify conductive heat flow to the land surface. In areas of recharge (downward percolation of water), heat flow to the land surface is decreased; whereas in areas of ground-water discharge to the atmosphere (upward flow) the normal heat flow to the land surface is increased. The magnitude of the distortion is related to the velocity and quantity of vertical flow of water.

Conductive heat flow is computed as follows:

$$
\text { HFU }=10^{-2} \mathrm{KI}
$$

where

HFU is heat-flow unit, in microcalories per square centimeter per second,

$K$ is thermal conductivity of the rock material, in millicalories per centimeter per second per degree Celsius, and

$I$ is the geothermal gradient, in degrees Celsius per kilometer.

The estimated $K$ values used in this report are summarized in table 2. From the formula it has been seen

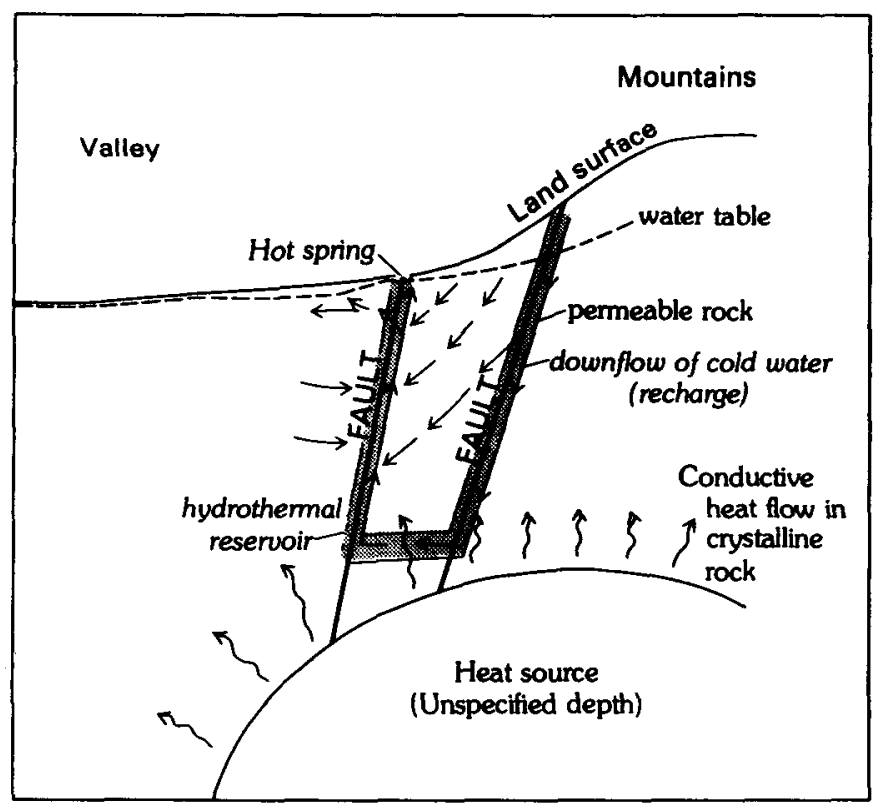

FIGURE 4.-Conceptual model of a hydrothermal convection cell.
TABLE 2.-Thermal-conductivity values used in this report

IValues based on work done in Nevada and Utah by Olmsted and others (1975, p. 64; Olmsted, oral commun., 1976) and Sass (written commun., 1975). See also Sass and others (1976)] $\frac{\begin{array}{c}\text { Estimated } \\ \text { conductivity valus }\end{array}}{\text { (n) }}$

\begin{tabular}{|c|c|c|}
\hline \multirow[t]{2}{*}{ Lithology } & \multicolumn{2}{|c|}{$\begin{array}{c}\text { conductivity values } \\
\left(\text { mcal/cm/ } / \mathrm{s}^{\circ} \mathrm{C}\right)\end{array}$} \\
\hline & Saturated & Unsaturated \\
\hline $\begin{array}{l}\text { Clay } \\
\text { Silt } \\
\text { Sand } \\
\text { Gravel } \\
\text { Basalt } \\
\text { Vesicular basalt } \\
\text { Sedimentary rocks } \\
\text { Igneous rocks of felsic to } \\
\text { intermediate composition }\end{array}$ & $\begin{array}{l}1.5-2.5 \\
2.5-3.0 \\
3.0-4.0 \\
4.0-6.0 \\
4.5-6.0 \\
3.5-5.0 \\
5.0-9.0\end{array}$ & $\begin{array}{l}1.5-2.0 \\
2.0-2.5 \\
2.0-3.5 \\
3.0-5.0 \\
3.0-5.5 \\
2.5-4.5 \\
4.0-7.0\end{array}$ \\
\hline
\end{tabular}

that, with no variation in regional heat flow, the geothermal gradient generally will vary as lithology varies. As a result, heat flow to the land surface is a more consistent index of geothermal-resource potential than shallow temperature-gradient data.

The values of thermal conductivity for the various lithologies, as listed in table 2 , are based on laboratory determinations using cores and drill cuttings. The values listed in the table are the ranges into which most samples fall. The factors that control thermal conductivity are: (1) texture of rock or alluvium, (2) mineral content, (3) layering within the rock, (4) porosity and pore size, (5) degree of water saturation, and (6) the dissolved mineral content of the saturating water. There may be additional factors.

Chemical composition of thermal spring waters can be used to estimate hydrothermal-reservoir temperatures. The geothermometers used in this report are listed in table 3 and are from Fournier and Rowe (1966) and Fournier and Truesdell (1973). The basic assumptions in using these geothermometers (Fournier and others, 1974) are: (1) Temperature-dependent reactions occur at depth; (2) there is an adequate supply of chemical constituents; (3) water-rock chemical equilibrium occurs at reservoir temperature; (4) re-equilibration at lower temperatures as the water flows to the surface is negligible; and (5) hot water is not diluted by shallow cold water. If mixing occurs, the least adversely affected geothermometers listed in table 3 are the $\mathrm{Na}-\mathrm{K}-\mathrm{Ca}$ geothermometer and the graphic method. Therefore, where temperature calculations differ and mixing is suspected, the Na-K-Ca and graphic-method calculations should be favored.

\section{DISTRIBUTION OF THERMAL WATERS}

In this report a thermal well or spring is defined as having a water temperature above the average landsurface ambient temperature, which, as stated previously, commonly ranges from $10^{\circ} \mathrm{C}$ to about $16^{\circ} \mathrm{C}$ depending on altitude and geographic location. In the 
TABLE 3.-Formulas for geothermometers used in this report [From R. O. Fournier, written commun., 1975 and 1977. Concentrations: Na, K, and Ca in molality; $\mathrm{SiO}_{2}$ in $\mathrm{mg} / \mathrm{kg}$, which is approximately the same as $\mathrm{mg} / \mathrm{L}$ )

\begin{tabular}{|c|c|c|}
\hline \multicolumn{2}{|c|}{$\begin{array}{l}\text { Formula } \\
\text { identification } \\
\text { used in table } 6\end{array}$} & Remarks \\
\hline \multirow[t]{2}{*}{ NKC } & $\begin{array}{l}\text { Na-K-Ca Geothermometer } \\
\mathrm{t}_{{ }^{\circ} \mathrm{C}}=\frac{1647}{\log (\mathrm{Na} / \mathrm{K}+\beta \log (\mathrm{Ca} / \mathrm{Na}}\end{array}$ & $\overline{2.24}-273$ \\
\hline & & $\begin{array}{l}\text { If magnesium concen- } \\
\text { trations are in excess of } \\
10 \mathrm{mg} / \mathrm{kg} \text { or if travertine } \\
\text { (tufa) is being deposited, } \\
\text { computed temperature } \\
\text { may be too high. } \beta=1 / 3 \text { in } \\
\text { all computations for } \\
\text { table } 7 \text {. }\end{array}$ \\
\hline \multicolumn{2}{|c|}{$\begin{array}{c}\text { Q Quartz (conductive) } \\
\text { Geothermometer }\end{array}$} & $\begin{array}{l}\text { Computed temperature } \\
\text { usable if spring dis- }\end{array}$ \\
\hline \multicolumn{2}{|r|}{$t_{\circ \mathrm{C}}=\frac{1309}{5.19-\operatorname{logSiO}{ }_{2}}-273$} & $\begin{array}{l}\text { charge is lower than } \\
\text { boiling. Computed tem- } \\
\text { peratures between } \\
120^{\circ} \mathrm{C} \text { and } 180^{\circ} \mathrm{C} \text { are of } \\
\text { questionable meaning, } \\
\text { because either chal- } \\
\text { cedony or quartz may be } \\
\text { controlling the silica } \\
\text { concentration. }\end{array}$ \\
\hline \multicolumn{2}{|r|}{$\begin{array}{c}\text { C Chalcedony Geothermometer } \\
t_{\mathrm{C}_{\mathrm{C}}}=\frac{1032}{4.69-\operatorname{logSiO}_{2}}-273\end{array}$} & $\begin{array}{l}\text { Used mostly in basalt } \\
\text { areas. Computed tem- } \\
\text { perature usable if } \\
<120^{\circ} \mathrm{C} \text {, but may be us- } \\
\text { able up to } 180^{\circ} \mathrm{C} \text {. }\end{array}$ \\
\hline \multicolumn{2}{|r|}{$\begin{array}{l}\text { S Amorphous Silica } \\
\text { (silica gel) Geothermometer } \\
\quad t_{{ }^{\circ} \mathrm{C}}=\frac{731}{4.52-\operatorname{logSiO})_{2}}-273\end{array}$} & $\begin{array}{l}\text { Computed temperature } \\
\text { should be considered if } \\
\text { opal deposits are pres- } \\
\text { ent: }\end{array}$ \\
\hline GM & $\begin{array}{l}\text { Graphic methods for es- } \\
\text { timating temperature of a } \\
\text { hot-water component in a } \\
\text { mixed water (Truesdell } \\
\text { and Fournier, 1977, and } \\
\text { Mariner, } \mathrm{R} \text {. H., written } \\
\text { commun., 1978). Use sol- } \\
\text { ubility curve of quartz } \\
\text { above } 120^{\circ} \mathrm{C} \text { and chal- } \\
\text { cedony solubility curve } \\
\text { below this temperature } \\
\text { where reservoir is volcanic } \\
\text { rock. }\end{array}$ & $\begin{array}{l}\text { A plot of dissolved silica } \\
\text { and enthalpy are used. } \\
\text { Valid for spring with } \\
\text { temperature lower than } \\
\text { about } 80^{\circ} \mathrm{C} \text { and flow rate } \\
\text { greater than about } 2 \mathrm{~L} / \mathrm{s} \text {. }\end{array}$ \\
\hline
\end{tabular}

low-altitude areas of southwestern Utah (near St. George), the highest ambient temperatures prevail. Elsewhere on valley floors, the range is commonly from $10^{\circ} \mathrm{C}$ to $14^{\circ} \mathrm{C}$

A map compiled by the U.S. Geological Survey for Utah (fig. 1) shows the eight KGRA's and lands prospectively valuable for geothermal resources. Not surprisingly, the general geographic distribution is the same as distribution of thermal springs described by Mundorff (1970, fig. 2). Table 4 summarizes information on the KGRA's.

The geographic distribution of thermal waters in Utah is shown in figure 5. This distribution is based on the thermal-spring report by Mundorff (1970) and on data collected during this study. The springs are
TABLE 4. -Known geothermal resource areas in Utah

[October 1976. Total area includes all land irrespective of ownership. Leased areas are 41 federal leases]

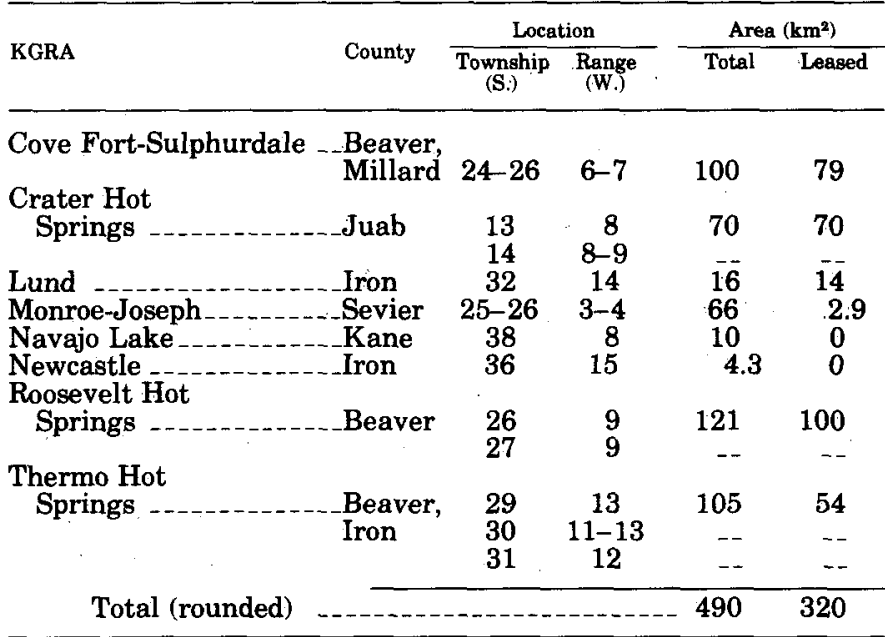

grouped into northwest, southwest, and Wasatch Range Front areas in figure 5. In table 5, the spring groups have been categorized on the basis of several hydrothermal characteristics. The springs of the southwest area have the most favorable characteristics. This is also the area of geothermal leasing of Federal lands (fig. 6). Most of the following discussions will be concerned with hydrothermal prospects in the southwest area.

Estimated reservoir temperatures for selected sites are given in table 6 . The temperature estimates are based on chemical analyses of geothermometers (table 3). Six prospects may have reservoir temperatures above $150^{\circ} \mathrm{C}$ and, therefore, they may have potential for generation of electricity: Roosevelt, Thermo, and Joseph Hot Springs, Newcastle area, the Cove FortSulphurdale area, and the Monroe-Red Hill Hot Springs complex. Six other hot springs listed in the table may have reservoir temperatures in the $90-150^{\circ} \mathrm{C}$ range, and therefore, they have value for space and process heating. The locations of the first group are shown in figure 1. The table contains location numbers for all the sites. In the table, graphic-method calculations are based on the quartz-solubility curve unless the chalcedony-solubility curve is indicated.

\section{DISCUSSION OF PROSPECTS}

In this section, geothermal systems that are considered to have the best potential for development are discussed. These systems include seven of the eight KGRA's in Utah and several other areas of interest. The Lund KGRA was not included because of lack of data. (See table 18 for temperature data for areas not discussed in this section.) 


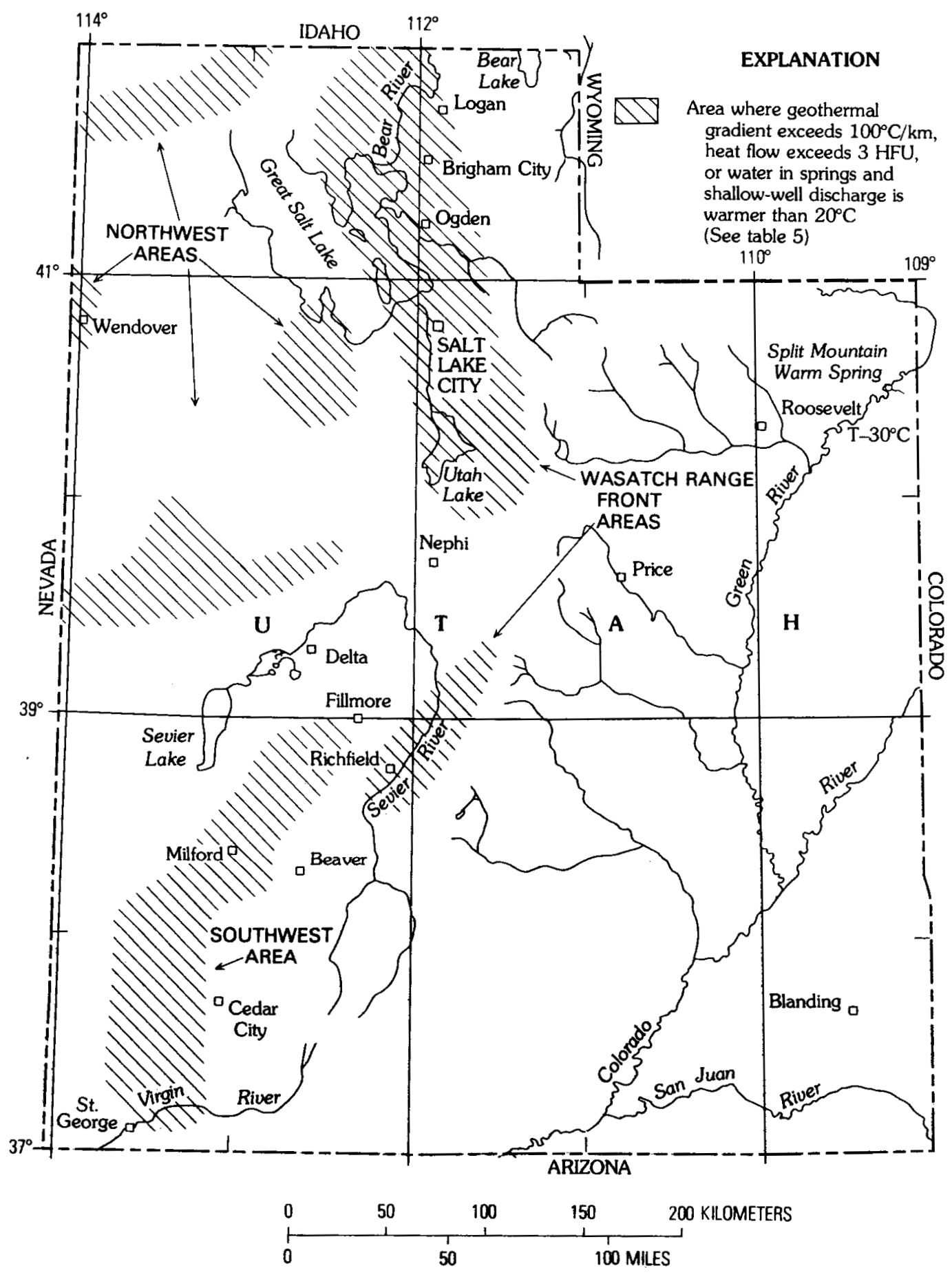

FiGURE 5.-Geothermal areas of Utah. 


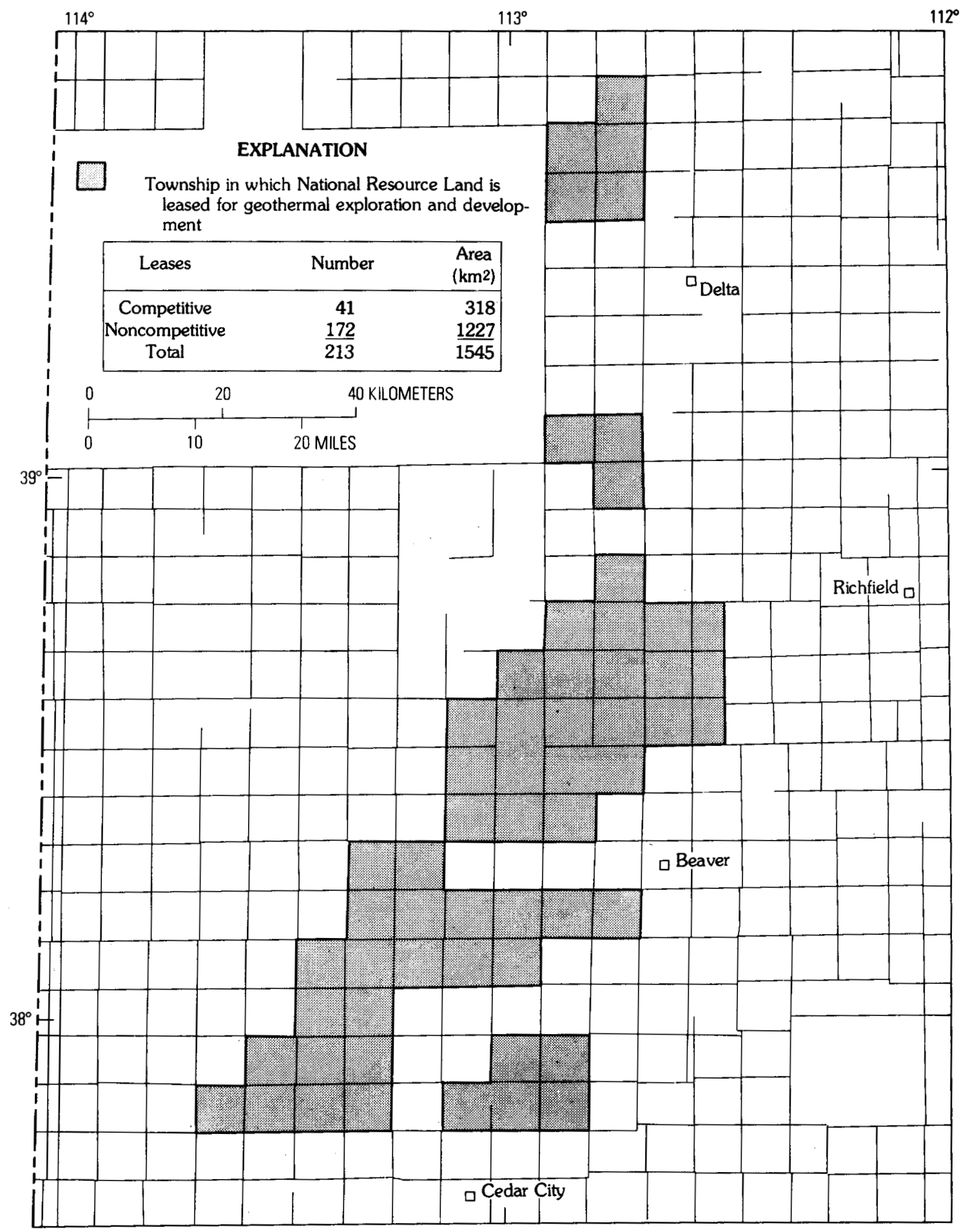

FIGURE 6. - Location of leased National Resource Land in Utah, September 1976. 
TABLE 5.-General characteristics of thermal-spring groups

[Group data based mostly on data in Mundorff (1970) and Milligan and others (1966). For location of groups, ee fig. 5]

\begin{tabular}{|c|c|c|c|c|c|c|}
\hline $\begin{array}{l}\text { Thermal } \\
\text { gpring } \\
\text { groups }\end{array}$ & Location & $\begin{array}{l}\text { Spring } \\
\text { discharge } \\
\text { rate }\end{array}$ & $\begin{array}{l}\text { Diesolved- } \\
\text { solids- } \\
\text { concentra- } \\
\text { tions }\end{array}$ & $\begin{array}{l}\text { Water tem- } \\
\text { perature at land } \\
\text { gurface } \\
\text { (" C) }\end{array}$ & $\begin{array}{l}\text { Silica con- } \\
\text { tent of } \\
\text { water } \\
\text { (mg/L) }\end{array}$ & $\begin{array}{l}\text { Spring deposits } \\
\text { and gas dis- } \\
\text { charges }\end{array}$ \\
\hline $\begin{array}{c}\text { Wasatch } \\
\text { Range. }\end{array}$ & $\begin{array}{l}\text { Along the major } \\
\text { fault zone } \\
\text { separating the } \\
\text { Basin and Range } \\
\text { province } \\
\text { from the Colo- } \\
\text { rado Plateaus } \\
\text { and the Middle } \\
\text { Rocky Mountains } \\
\text { provinces. }\end{array}$ & $\begin{array}{l}\text { Wide } \\
\text { ranges. }\end{array}$ & $\begin{array}{l}\text { Wide } \\
\text { ranges. }\end{array}$ & $\begin{array}{l}\text { 20-77; hottest } \\
\text { springs are at } \\
\text { the south end } \\
\text { of the area. }\end{array}$ & $\begin{array}{l}\text { 15-85; } \\
\text { highest } \\
\text { at the } \\
\text { south end } \\
\text { of the area. }\end{array}$ & Travertine common. \\
\hline $\begin{array}{l}\text { North- } \\
\text { west } \\
\text { area. }\end{array}$ & $\begin{array}{l}\text { In the Basin and } \\
\text { Range province, } \\
\text { an area of } \\
\text { above normal } \\
\text { conductive } \\
\text { heat flow. }\end{array}$ & -_do & . do & $\begin{array}{l}\text { Generally low. } \\
18-42 \text {, except } \\
\text { for Crater Hot } \\
\text { Springs }\left(87^{\circ} \mathrm{C}\right) \\
\text { near south end } \\
\text { of area. }\end{array}$ & $\begin{array}{l}\text { 5-33; } \\
\text { Crater Hot } \\
\text { Springs } \\
\text { (57-59) } \\
\text { near south } \\
\text { end of } \\
\text { area. }\end{array}$ & $\begin{array}{l}\text { Travertine common; } \\
\text { some hydrogen } \\
\text { sulfide. }\end{array}$ \\
\hline
\end{tabular}

\section{ROOSEVELT HOT SPRINGS AND THE COVE} FORT-SULPHURDALE AREAS

The locations of these two adjacent KGRA's are shown in figure 1. Roosevelt Hot Springs (C-26-9)34dcS, is on the west flank of the Mineral Mountains in Beaver County, about $20 \mathrm{~km}$ northeast of the town of Milford. Cove Fort, (C-25-7)30, and Sulphurdale, (C-26-7)7, are about $25 \mathrm{~km}$ northeast of Roosevelt Hot Springs near the northeastern corner of Beaver County and on the west flank of the Tushar Mountains and the Pavant Range. The surface geology of the two areas is quite different. At Roosevelt Hot Springs, an alluvial valley lies to the west and a large Tertiary pluton of granite to the east. At Cove Fort and Sulphurdale, the dominant lithology is young basaltic lava flows, commonly of Quaternary age.

Lee $(1908$, p. 21) describes a silica deposit on the southwestern flank of the Mineral Mountains and about $25 \mathrm{~km}$ south of Roosevelt Hot Springs. He reports that cold water issues from a mound of silica $400 \mathrm{~m}$ in diameter. This geologic feature was not visited as part of this study, but if this is a hot-spring deposit, it may be an area of geothermal-resource potential. From the location description, the mound probably is at (C-29-10)24c.

Phillips Petroleum Co., Thermal Power Corp., and the University of Utah are actively exploring the hydrothermal system in the Roosevelt Hot Springs area. Phillips and Thermal Power, who have made many geophysical surveys, have drilled a total of nine deep exploratory wells (as of April 1977) to depths commonly less than $1,500 \mathrm{~m}$. Results of well tests reportedly were very favorable, and additional exploration and development wells are planned. The University has made extensive geophysical surveys, funded by the National Science Foundation, the U.S. Department of Energy (formerly the Energy Research and Development Administration), and the U.S. Geological Survey, and the results were published in a series of reports. Because of these very extensive exploration activities, which have been continuing since the early 1970's, no additional field data were collected in this area as part of this study.

The geology of the Roosevelt Hot Springs area has been mapped by Petersen (1975), Parry, Berson, and Miller (1976, p. 22), and Liese (1957). Petersen mapped 10 lithologic units, including 4 units of hot-spring deposits. According to Patrick Muffler (written commun., 1976), the heat source is related to Pleistocene rhyolites that crop out on the west flank of the Mineral Mountains (fig. 1). Rhyolite as young as 490,000 years has been identified. Hydrothermally altered ground is common in the area. Brown $(1977$, p. 5) estimates the age of hydrothermally deposited opal near Roosevelt Hot Springs at roughly 350,000 years.

Basin and Range faulting controls the location of Roosevelt Hot Springs. One of the Basin and Range faults, the Dome fault, is marked by an abundance of siliceous sinter (opal) in mounds for a distance of nearly $5 \mathrm{~km}$. The model shown in figure 6, with some 
TABLE 6.-Estimated reservoir temperatures derived by geothermometer formulas for springs (and one well) with temperatures greater than $50^{\circ} \mathrm{C}$ and silica concentrations greater than $50 \mathrm{mg} / \mathrm{L}$

[For formulas, see table 3. Chemical data mostly from Mundorff, 1970, table 1. Silica: First number is concentration for thermal-water sample; remaining numbers are concentrations for nearby cold water sources. Discharge temperature: First number is for thermal-water sample; remaining numbers are for cold-water sources and correspond to silica concentrations in aearby cold water sources. Discharge temperature: First number is for thermal-water sanple; remaing column

\begin{tabular}{|c|c|c|c|c|c|c|c|c|c|c|}
\hline \multirow[b]{2}{*}{$\begin{array}{l}\text { Hydrothermal } \\
\text { source }\end{array}$} & \multirow[b]{2}{*}{ Location } & \multicolumn{2}{|c|}{$\begin{array}{c}\text { Concentrations in } \\
\text { molality }\left(\times 10^{-8}\right)\end{array}$} & \multicolumn{2}{|c|}{$\begin{array}{c}\text { Concentrations } \\
\text { in } \mathrm{mg} / \mathrm{L}\end{array}$} & \multicolumn{2}{|c|}{$\begin{array}{c}\text { Temperature } \\
\left({ }^{\circ} \mathrm{C}\right)\end{array}$} & \multirow{2}{*}{$\begin{array}{l}\text { Formula } \\
\text { used to } \\
\text { compute } \\
\text { reservoir } \\
\text { temper- } \\
\text { ature }\end{array}$} & \multirow{2}{*}{$\begin{array}{l}\text { Estimated } \\
\text { reservoir } \\
\text { temper- } \\
\text { ature, in } \\
{ }^{\circ} \mathrm{C} \\
\text { (rounded) }\end{array}$} & \multirow[b]{2}{*}{ Remarks } \\
\hline & & $\underset{(\mathrm{Ca})}{\text { Calcium Sodium }}$ (Na) & $\begin{array}{l}\text { Potas- } \\
\text { sium } \\
(\mathbf{K})\end{array}$ & $\begin{array}{l}\text { Magne- } \\
\text { sium } \\
(\mathrm{Mg})\end{array}$ & $\left(\mathrm{SiO}_{2}\right)$ & $\begin{array}{c}\text { Dis- } \\
\text { charge }\end{array}$ & $\begin{array}{l}\text { Computed } \\
\text { reservoir }\end{array}$ & & & \\
\hline
\end{tabular}

Christensen well

$\begin{array}{lllllllllcc}\text { Newcastle, UT' _-(C-36-15)20bb } & 1.45 & 11.74 & 0.54 & & 0.4 & 99 & 95 & 166 & \text { NKC } \\ & & & & & & 34 & 13 & 138 & \text { Q } \\ & & & & & 62 & 12 & 110 & \mathrm{C} \\ & & & & & & & 150-160 & \mathrm{GM}\end{array}$

Cove Fort-

Sulphurdale _...T. 25 and $26 \mathrm{~S}$.

Crater

Hot Springs _... (C-14-8)10S

R. 6 and $7 \mathrm{~W}$

$8.61 \quad 35.50 \quad 1.23 \quad{ }^{1} 68$

Crystal

\begin{tabular}{|c|c|c|c|c|c|c|c|c|c|}
\hline Hot Springs & $\ldots(C-4-1) 11$ and & 2.54 & --- & $-\cdots \cdot$ & ${ }^{1} 24$ & 73 & 58 & $\begin{array}{r}120 \\
92\end{array}$ & $\stackrel{Q}{C}$ \\
\hline $\begin{array}{l}\text { atton } \\
\text { Hot Springs }\end{array}$ & $\ldots(C-22-6) 35 d d S$ & 11.6 & --- & --- & 89 & $\begin{array}{l}44 \\
37\end{array}$ & $\begin{array}{l}36 \\
14\end{array}$ & $\begin{array}{c}66 \\
100-110\end{array}$ & $\stackrel{\mathrm{C}}{\mathrm{GM}}$ \\
\hline $\begin{array}{l}\text { Hot Springs } \\
\text { Hoph }\end{array}$ & $---(C-25-4) 23 S$ & 7.04 & 62.64 & 1.73 & ${ }^{1} 36$ & $\begin{array}{l}85 \\
50\end{array}$ & $\begin{array}{l}65 \\
12\end{array}$ & $\begin{array}{l}101 \\
170\end{array}$ & $\stackrel{\mathrm{C}}{\mathrm{GM}}$ \\
\hline $\begin{array}{l}\text { leadow } \\
\text { Hot Springs }\end{array}$ & $-\ldots(C-22-6) 26 \mathrm{ccS}$ & 10.8 & 44.37 & 3.58 & ${ }^{1} 114$ & $\begin{array}{l}47 \\
37\end{array}$ & $\begin{array}{l}41 \\
14\end{array}$ & $\begin{array}{r}69 \\
120\end{array}$ & $\stackrel{\mathrm{C}}{\mathrm{GM}}$ \\
\hline $\begin{array}{l}\text { Ionroe } \\
\text { Hot Springs }\end{array}$ & $-(C-25-3) 10 \mathrm{dd} S$ & 7.01 & 24.06 & 1.25 & 149 & $\begin{array}{l}51 \\
36 \\
33\end{array}$ & $\begin{array}{l}65.5 \\
13 \\
14\end{array}$ & $\begin{array}{r}73 \\
115\end{array}$ & $\underset{\mathrm{GM}}{\mathrm{C}}$ \\
\hline $\begin{array}{l}\text { den } \\
\text { Hot Springs }\end{array}$ & $(B-6-1) 23 \operatorname{ccS}$ & 8.41 & 119.19 & 10.40 & 8 & $\begin{array}{l}53 \\
30\end{array}$ & $\begin{array}{l}58 \\
10\end{array}$ & $\begin{array}{r}323 \\
75 \\
90\end{array}$ & $\begin{array}{c}\mathrm{NKC} \\
\mathrm{GM}^{2}\end{array}$ \\
\hline $\begin{array}{l}\text { ed Hill } \\
\text { Hot Spring }\end{array}$ & - (C-25-3)11 caS & 5.99 & 26.88 & 1.35 & 134 & $\begin{array}{l}83 \\
36 \\
33\end{array}$ & $\begin{array}{l}75 \\
13 \\
14\end{array}$ & $\begin{array}{r}99 \\
160\end{array}$ & $\stackrel{\mathrm{C}}{\mathrm{GM}}$ \\
\hline $\begin{array}{l}\text { oosevelt } \\
\text { Hot Springs }\end{array}$ & $(C-26-9) 34 \mathrm{dcS}$ & .475 & 90.48 & $\begin{array}{c}12.07 \\
:\end{array}$ & 3.3 & 405 & 85 & $\begin{array}{l}293 \\
234 \\
109\end{array}$ & $\begin{array}{c}\mathrm{NKC} \\
\mathrm{Q} \\
\mathrm{S}\end{array}$ \\
\hline $\begin{array}{l}\text { tinking } \\
\text { Hot Springs }\end{array}$ & $\ldots(\mathrm{B}-10-3) 30 \mathrm{bbS}$ & 22.40 & 487.2 & 16.82 & 1335 & $\begin{array}{l}53 \\
30\end{array}$ & $\begin{array}{l}51 \\
10\end{array}$ & $\begin{array}{l}75 \\
95\end{array}$ & $\underset{\mathrm{GM}^{2}}{\mathrm{C}}$ \\
\hline $\begin{array}{l}\text { hermo } \\
\text { Hot Springs }\end{array}$ & $(\mathrm{C}-30-12) 21 \mathrm{~S}$ & 2.07 & 15.57 & 1.25 & 9.7 & $\begin{array}{r}108 \\
23 \\
49\end{array}$ & $\begin{array}{l}82.5 \\
14 \\
14\end{array}$ & $\begin{array}{l}199 \\
115 \\
141 \\
70-200\end{array}$ & $\begin{array}{c}\text { NKC } \\
\mathrm{C} \\
\mathrm{Q} \\
\mathrm{GM}\end{array}$ \\
\hline
\end{tabular}

140-170 No springs present. Difference in computed temperatures may indicate mixing of ther mal and nonthermal waters.

$200 \pm$ Estimate from Renner, White, and Williams (1975, p. 21).

110-140 Reservoir rock may not be basalt. Differences in computed temperatures may indicate mixing of therma and nonthermal waters.

90-120 Mixed water. Dissolved-solids are $1,665 \mathrm{mg} / \mathrm{L}$.

70-110 Subsurface temperature of $67^{\circ} \mathrm{C}$ measured in nearby shallow well. Mixed water.

$100-170$

70-120 Mixed water

70-120 Reservoir temperature probably the same as for Red Hill Hot Springs or $100^{\circ}-160^{\circ} \mathrm{C}$.

75-90 Reservoir temperature computed with formula NKC is probably too high. Dis. solved solids are $8,820 \mathrm{mg} / \mathrm{L}$

100-160 Difference in computed temperatures may indicate mixing of thermal and nonthermal waters.

260-290 Subsurface temperature as high as $262^{\circ} \mathrm{C}$ reported by Phillips Petroleum Co. Opal deposits.

75-95 Dissolved solids are about $36,000 \mathrm{mg} / \mathrm{L}$

140-200 Travertine deposits indicate that temperature computed with formula NKC may be too high. Difference in computed temperatures may. indicate mixing, of thermal and non-thermal waters 
modifications, is perhaps representative of this hydrothermal system. Recharge to the system probably occurs only in a permeable zone in the Mineral Mountains, the same general area where much of the recharge for Milford Valley originates. Nearly all the hot, saline water rising as part of the convection cell enters relatively shallow, fresh-water aquifers and then mixes with the fresh water as it flows westward toward the axis of Milford Valley (Mower and Cordova, 1974, pl. 4).

Roosevelt Hot Springs, the only thermal spring in the area, has had a very small flow during historic time, on the order of $1 \mathrm{~L} / \mathrm{s}$ or less (Mundorff, 1970, p. 42). Since about the mid-1960's, the only flow to the surface has been a small seep supporting a very small area of tules. The measured temperature of the spring was $85^{\circ} \mathrm{C}$ in 1950. The spring was sampled at that time, and according to Mundorff (1970, p. 16), silica had a concentration of $405 \mathrm{mg} / \mathrm{L}$ and the dissolved solids were $7,040 \mathrm{mg} / \mathrm{L}$. The dominant ions were sodium and chloride.

The estimated reservoir temperature (table 6), on the basis of geothermometer calculations and reported well temperatures, is $260^{\circ}-290^{\circ} \mathrm{C}$. If the reservoir temperature is dependent entirely on regional heat flow, the maximum depth of circulation would be about 6-7 km. This calculation is based on estimated reservoir temperature, a conductive heat flow of $2 \mathrm{HFU}$, mean thermal conductivity of $5 \times 10^{-3} \mathrm{cal} / \mathrm{cm} / \mathrm{s}^{\circ} \mathrm{C}$, and an ambient land-surface temperature of about $10^{\circ} \mathrm{C}$. If a shallow, magmatic-heat source is present, the local heat flow could be much higher and the depth to the hydrothermal reservoir would be less. The amount of heat and water discharged by the hydrothermal system under native conditions was not estimated.

No data have been collected as part of this study at the Cove Fort-Sulphurdale area for two reasons: (1) Phillips Petroleum Co., Union Oil Co. of California, and other companies are actively exploring the area, and (2) the only surface manifestations of hydrothermal activity are sulfur deposits, hydrothermally altered ground, and gaseous emissions at Sulphurdale. Mundorff (1970, p. 50) lists mine drainage, sampled by Lee (1908, p. 19-20) as having 10,810 ppm (parts per million) of dissolved solids, sulfate concentrations of $7,600 \mathrm{ppm}$, and iron concentration of $1,360 \mathrm{ppm}$.

Most of the Federal land in the KGRA was leased to Union Oil Co. of California, but no deep holes have been completed to date (1977). In 1976, Union Oil Co. failed to penetrate more than about $300 \mathrm{~m}$ in a hole scheduled to be drilled much deeper. Additional deep-well drilling attempts are planned.

The reservoir temperature has been estimated by Renner, White, and Williams $(1975$, p. 21$)$ to be approximately $200^{\circ} \mathrm{C}$. On the basis of the estimated reservoir temperature, a conductive heat flow of $2 \mathrm{HFU}$, estimated mean thermal conductivity of $5 \times 10^{-3} \mathrm{cal} / \mathrm{cm} / \mathrm{s}^{\circ} \mathrm{C}$ for the rock, and an ambient land-surface temperature of $10^{\circ} \mathrm{C}$, the maximum depth of circulation to the hydrothermal reservoir is computed to be about $5 \mathrm{~km}$. If a shallow, magmatic-heat source were present, the local geothermal gradient may be much higher and the depth of circulation could be much less.

Recharge for the area and for the hydrothermal system is believed to come from the Tushar and Pavant Ranges to the east. Ground water in the area probably flows generally westward or northwestward, and it probably is the only significant means of heat and water discharge from the hydrothermal system.

At Neels, a railroad siding about $60 \mathrm{~km}$ north of Roosevelt Hot Springs at (C-20-8)28b, Lee (1908, p. 32) reports that a well was drilled to a depth of $609 \mathrm{~m}$, and hot water was encountered at a depth of $549 \mathrm{~m}$. An entry in Lee's log of the well $(1908, p .33)$ states that gas under pressure was sufficient to raise $2,800 \mathrm{~kg}$ of drilling tools $122 \mathrm{~m}$ up the well bore. According to Kenneth Bull (oral commun., 1977), gas-discharging vents have been found in the young lava-flow area northwest of Cove Fort and north of the Mineral Mountains. The triangular area including Roosevelt Hot Springs and the Cove FortSulphurdale area and extending northward to Neels probably has the best potential for geothermal development in Utah.

\section{THERMO HOT SPRINGS}

Thermo Hot Springs is about $50 \mathrm{~km}$ southwest of Roosevelt Hot Springs along the axial drainage of the northern part of the Escalante Desert (Milford Valley) at (C-30-12)21S and 28S. Schmoker (1972) interprets aeromagnetic and gravity data to indicate the general area to be underlain by a large Tertiary, intrusive pluton of tabular form having a thickness of about $8 \mathrm{~km}$. The mountains to the northwest, the Shauntie Hills, are a horst dipping to the southeast under the Tertiary volcanic rocks and extending at least as far south as the Thermo Hot Springs area. Schmoker interprets Milford Valley as a graben with an alluvial thickness ranging from 760 to $1,070 \mathrm{~m}$.

The Black Mountains, southeast of the springs, are mostly volcanic rocks associated with a possible caldera (Crosby, 1973) that range in age from 19 to 26 million years (Rowley, 1978). Rowley mapped a rhyolite about 3 $\mathrm{km}$ east of Thermo Hot Springs having an age of 10.3 million years (fig. 7). Rhyolites and other quartzbearing volcanic rocks of Pliocene age have been mapped by Erickson (1973). Their occurrence is widespread in both the Shauntie Hills and the Black Mountains. 


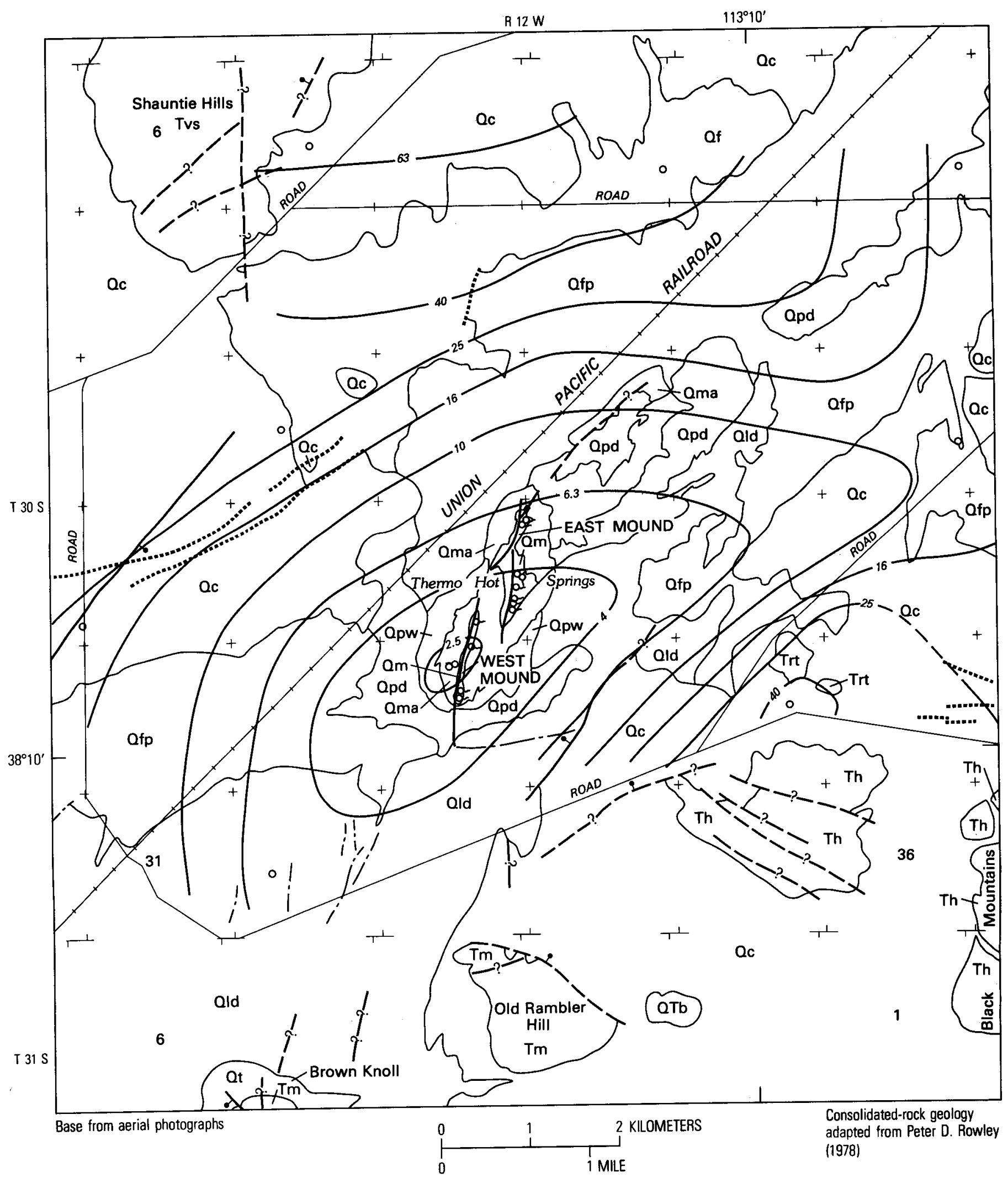

FigURE 7.-Reconnaissance geologic map of the Thermo Hot Springs area, and audio-magnetotelluric configuration for the Thermo Hot Springs area. 
CORRELATION OF MAP UNITS

\begin{tabular}{|c|c|c|c|c|c|c|c|}
\hline am & Oma & Opw & Opd & Ofp & af & \multirow{2}{*}{ Holocene } & \multirow{2}{*}{ QUATER- } \\
\hline Qc & \multirow[t]{4}{*}{ Qld } & & & & & & \\
\hline Qt & & & & & & \multirow{3}{*}{$\begin{array}{l}\text { Pleistocene } \\
\text { Pleistocene } \\
\text { and } \\
\text { Pliocene } \\
\text { Pliocene }\end{array}$} & \\
\hline QTb & & & & & & & \\
\hline Trt & & & & & & & \\
\hline Th & \multirow{3}{*}{ Tvs } & & & & & \multirow{3}{*}{ - Miocene } & TERTLARY \\
\hline & & & & & & & \\
\hline Tm & & & & & & & \\
\hline
\end{tabular}

DESCRIPTION OF MAP UNITS

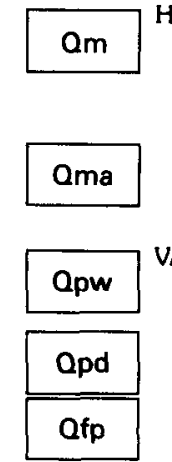

HYDROTHERMALLY - RELATED DEPOSTTS

Spring-mound deposits-Windblown quartz sand collecting in areas of spring discharge; mostly fine-to medium-grained, light tan. Mound surface commonly white where salt has accumulated from evaporated water. Minor amount of travertine and siliceous sinter

Spring-mound apron deposits-Mostly windblown quartz sand collecting in damp areas, some dark-gray basalt fragments. Sand tine- to medium-grained, tan

ALLEY_FLOOR DEPOSTS

Wet-playa deposits - Light-tan, sandy silt and clay. Land surface soft due to saturation of water to the land surface. Surface whitte due to deposition from evaporated water

Dry-playa deposits-Mostly tan sandy silt and clay. Land surface is hand most of the time

Flood-plain deposits-Mostly light-tan to light-brown silt and day, bocally indudes some sand. Deposits underlie hard surface marked by abundant arid distinctive stream-channel meander scars

Qld Dissected lake deposits-Mostly light-tan to light-brown, fine- to medlum-grained quart sand and silt minor amounts of dark-gray volcanic rock tragments up to $2 \mathrm{~cm}$ in diameter locally present. Includes sand dunes that form low hills souttwest of the spring mounds

ALLUVAL_APRON DEPOSITS

Of Alluvid fan of Shauntie Hits drainage-Light-tan to light-brown sity fine- to medium-grained sand. Land surface is commonly soft

Qc Colluvium-Tan to brown fine- to medium-grained sand and silt, commonly with a pootly developed gravel pavement on the land surface. Indudes some graved bars and sand dunes. Major drainage channels have dark-gray volcanic rock boulders up to $30 \mathrm{~cm}$ in diameter

Talus of Mount Dutton Formation-Accumulations of angular blocks of rock

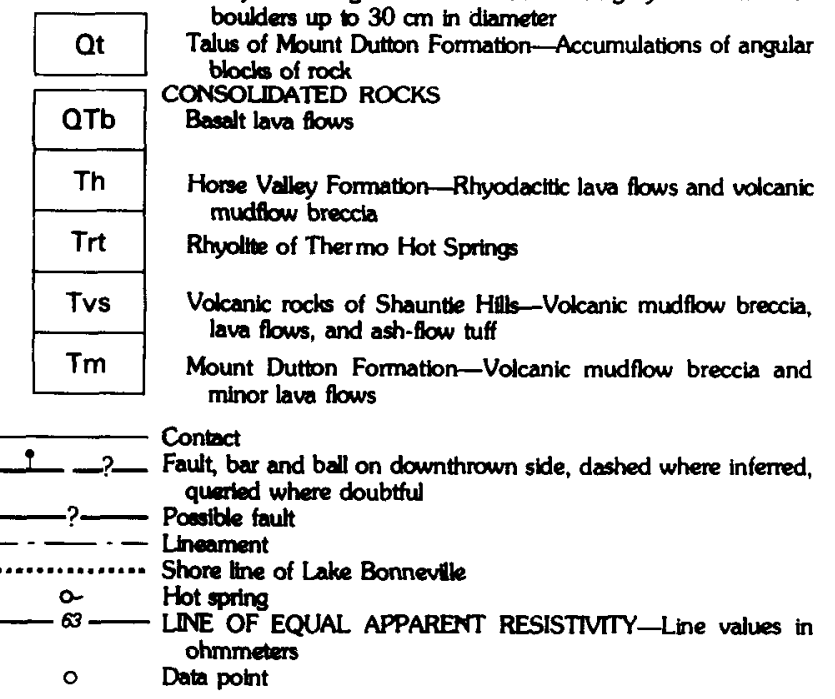

FIGURE 7.-_Continued.
Fault-controlled Thermo Hot Springs flow from two north-trending spring-controlled mounds each of which is about $1 \mathrm{~km}$ long and ranges from about 50 to about $200 \mathrm{~m}$ wide (fig. 8). The mounds, which rise about $4-8 \mathrm{~m}$ above the surrounding valley floor, are probably composed mostly of windblown sand and lesser amounts of siliceous sinter and travertine debris. On the spring mounds, a total of 69 spring orifices were inventoried (table 16 in table section), 54 of which were on the west mound. The total observed spring flow was estimated to be about $2 \mathrm{~L} / \mathrm{s}$ and the maximum observed water temperature was $82.5^{\circ} \mathrm{C}$.

Mundorff, $(1970$, p. 18) lists four chemical analyses of water samples from Thermo Hot Springs. The maximum silica concentration was $108 \mathrm{mg} / \mathrm{L}$ and the dissolved solids were $1,500 \mathrm{mg} / \mathrm{L}$. The dominant ions were sodium and sulfate.

The estimated reservoir temperature (table 6), based on chemical analyses of water samples and geothermometer (table 3) calculations, is $140^{\circ}-200^{\circ} \mathrm{C}$. The maximum depth of circulation of water to the hydrothermal reservoir probably is between 3 and $4 \mathrm{~km}$, on the basis of a regional conductive heat flow of $2 \mathrm{HFU}$, mean thermal conductivity of the rock and alluvium of about $4.5 \times 10^{-3} \mathrm{cal} / \mathrm{cm} / \mathrm{s}^{\circ} \mathrm{C}$, and an ambient landsurface temperature of $12^{\circ} \mathrm{C}$. The calculation assumes the absence of any shallow magmatic-heat source.

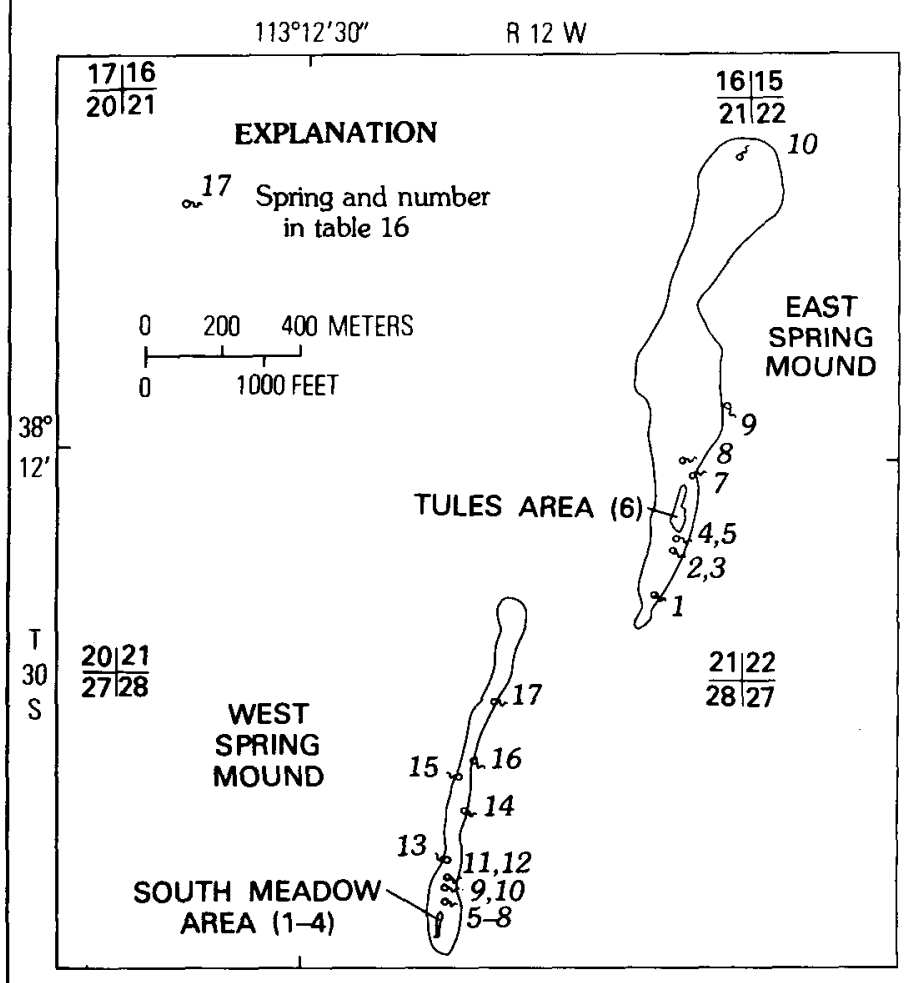

Figure 8.-Distribution of orifices at Thermo Hot Springs. 


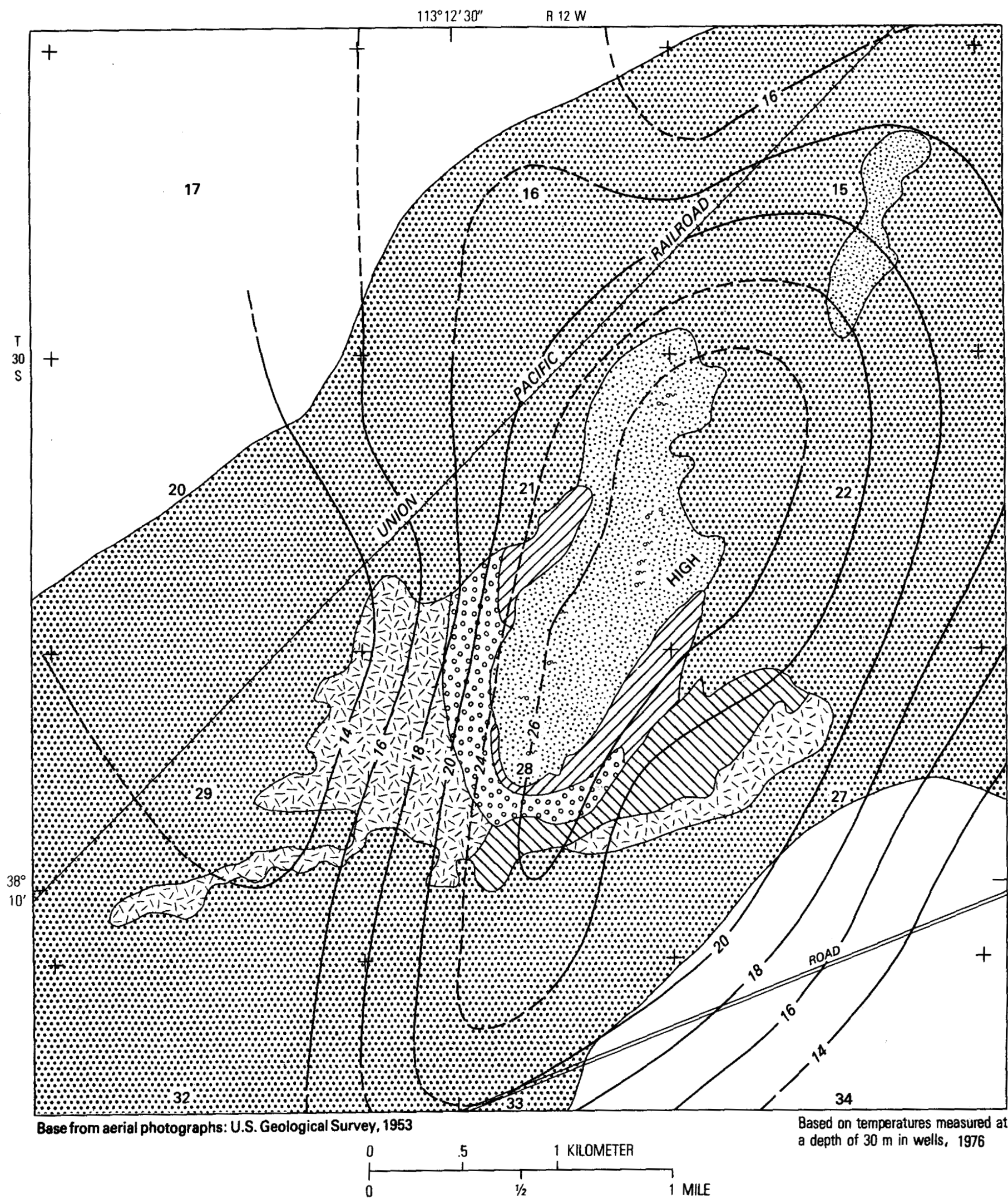

FIGURE 9.--Temperature at a depth of $30 \mathrm{~m}$ in the Thermo Hot Springs area; and distribution of vegetation in Thermo Hot Springs area, 1976. 
Recharge for the hydrothermal system probably occurs in the nearby mountains or seeps downward through a permeable zone from the saturated alluvium of the valley. To estimate the amount of mixing of the upflowing thermal water with nonthermal water, a graphic method developed by Truesdell and Fournier (1977) was used. The amount of mixing was estimated using temperature and silica-concentration data for thermal and nonthermal ground water in the area. For nonthermal ground water, the range of silica concentrations used in the calculation was $23-49 \mathrm{mg} / \mathrm{L}$ and a water temperature of $14^{\circ} \mathrm{C}$ (table 6).

The results suggest that as the thermal water rises, it mixes with nonthermal water at an approximate ratio of 40 percent thermal water to 60 percent nonthermal water and enters a shallow aquifer within the alluvial valley fill. Some of this mixed water is discharged by Thermo Hot Springs, but most is discharged from a shallow water table by evapotranspiration of phreatophytes.

The distribution of the mixed thermal-nonthermal water in the alluvium is shown on three maps. Figure 7 includes an audio-magnetotelluric map which shows

\section{DESCRIPTION OF MAP UNITS}

HYDROTHERMALLY(?)—RELATED PHREATOPHYTES Mostly saltgrass and pickleweed; locally some greasewood, rabbitbrush, and saltbush. Land surface commonly covered with salt, and soil is damp to land surface. Depth to water table generally less than $1 \mathrm{~m}$. Includes tules around spring orifices and areas of ponded water

Bare playa soil except for locally scattered mounds of greasewood and saltbush. Land surface white with abundant salt east of spring mounds. Smaller salt accumulation west of mounds. Soils damp and very soft. Depth to water table generally less than $0.5 \mathrm{~m}$

Mostly bare playa; locally some saltgrass and pickleweed. Land surface less salty and soils less damp than bare playa (preceding unit). Depth to water table generally less than $2 \mathrm{~m}$

Greasewood and rabbitbrush mixed with lesser amounts of pickleweed and saltgrass. Depth to water table probably ranges between 1 and $3 \mathrm{~m}$

Greasewood growing on a playa; land surface locally salty. Depth to water table probably ranges between 2 and $5 \mathrm{~m}$

OTHER PHREATOPHYTES

Greasewood, rabbitbrush, and saltbush. Mixed with big sage and shadscale on higher parts of the area. Proportion of big sage and shadscale increases with increase in altitude. Depth to water table ranges between 3 and $15 \mathrm{~m}$

XEROPHYTES

Big Sage, shadscale, and associated xerophytes growing on upland areas where depth to water table exceeds about $15 \mathrm{~m}$; plants obtain moisture only from soils above water table

a Hot spring

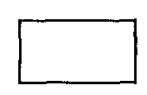
approximately located

Figure 9.-Continued. the low-resistivity, elongated body of thermal water underlying the general spring-mound area; this body has its long axis parallel to the northeastward direction of ground-water flow as defined by Mower and Cordova (1974, pl. 4). Figure 9 includes temperatures measured at a depth of $30 \mathrm{~m}$ below land surface. In addition to the thermal anomaly near the spring mounds, two additional thermal areas are shown to the southeast and east. These two areas are probably associated with permeable fault zones separate from the permeable zones underlying the spring mounds. Contours of conductive heat flow on figure 10 show similar patterns.

Figure 9 shows the distribution of vegetation in the Thermo Hot Springs area. Three types of vegetation are shown: (1) The xerophytes in the northwestern and southeastern parts of the map that do not root to or use ground water, (2) greasewood, rabbitbrush, and saltbush that obtain much of their water from the shallow ground water in the valley fill reservoir, and (3) phreatophytes near the spring mounds that use rising thermal water at rates greater than the surrounding phreatophytes. Net mixed-water discharge by phreatophytes from the hydrothermal system is computed in table 7 as the difference between the gross discharge of the area and the estimated discharge if no hydrothermal system were present. The estimated discharge of mixed water by phreatophytes is $1.4 \times 10^{-6}$ $\mathrm{m}^{3} / \mathrm{yr}$ or equals a continuous flow of $44 \mathrm{~L} / \mathrm{s}$. The portion of this flow that is deep-circulating thermal water is about 40 percent or $18 \mathrm{~L} / \mathrm{s}$.

Olmsted and others (1975, p. 66, p. 220-224) have developed two methods of estimating conductive heat discharge from hydrothermal systems. Their method (A) is based on a subsurface-temperature map and the thermal gradient from the map's datum plane to the land surface. Method (B) is based on a heat-flow map for a hydrothermal system. Because both methods use the same data base, only method (B) is presented in table 8 .

Method (B) yields a conductive heat discharge from the system of $16 \times 10^{13} \mathrm{cal} / \mathrm{yr}$; method (A), $15 \times 10^{13}$ cal/yr. A third method was also used, based on an estimated reservoir temperature of $200^{\circ} \mathrm{C}$ (table 6), convective water flow through the deep hydrothermal reservoir of $0.6 \times 10^{6} \mathrm{~m}^{3} / \mathrm{yr}$, and an ambient land-surface temperature of $12^{\circ} \mathrm{C}$. This last method yielded the lowest of the three estimates, $11 \times 10^{13} \mathrm{cal} / \mathrm{yr}$, and was applied only to the area of evapotranspiration near the spring mounds. In that computation of convective flow, because no increment for warm ground-water flow to the northeast from the thermal areas was included, the estimate of total heat discharge is probably too small. The value $15 \times 10^{13} \mathrm{cal} / \mathrm{yr}$ was selected to represent the probable heat discharge from the entire hydrothermal system. As depth increases, the three heat anomalies 
shown in figures 9 and 10 probably expand and merge into a single hydrothermal system.

\section{SOUTHWESTERN ESCALANTE DESERT}

The southwestern part of the Escalante Desert is northwest of Cedar City (fig. 1). Three communities are referred to in this section: Newcastle ([C-36-15]17), Beryl ([C-33-16]32), and Lund ([C-32-14]21) (fig. 11). Newcastle is in the southeastern part of the desert, about $40 \mathrm{~km}$ west of Cedar City. Beryl is northwest of the valley axis and $30 \mathrm{~km}$ northwest of Newcastle. Lund is $25 \mathrm{~km}$ northeast of Beryl along the Union Pacific Railroad tracks.

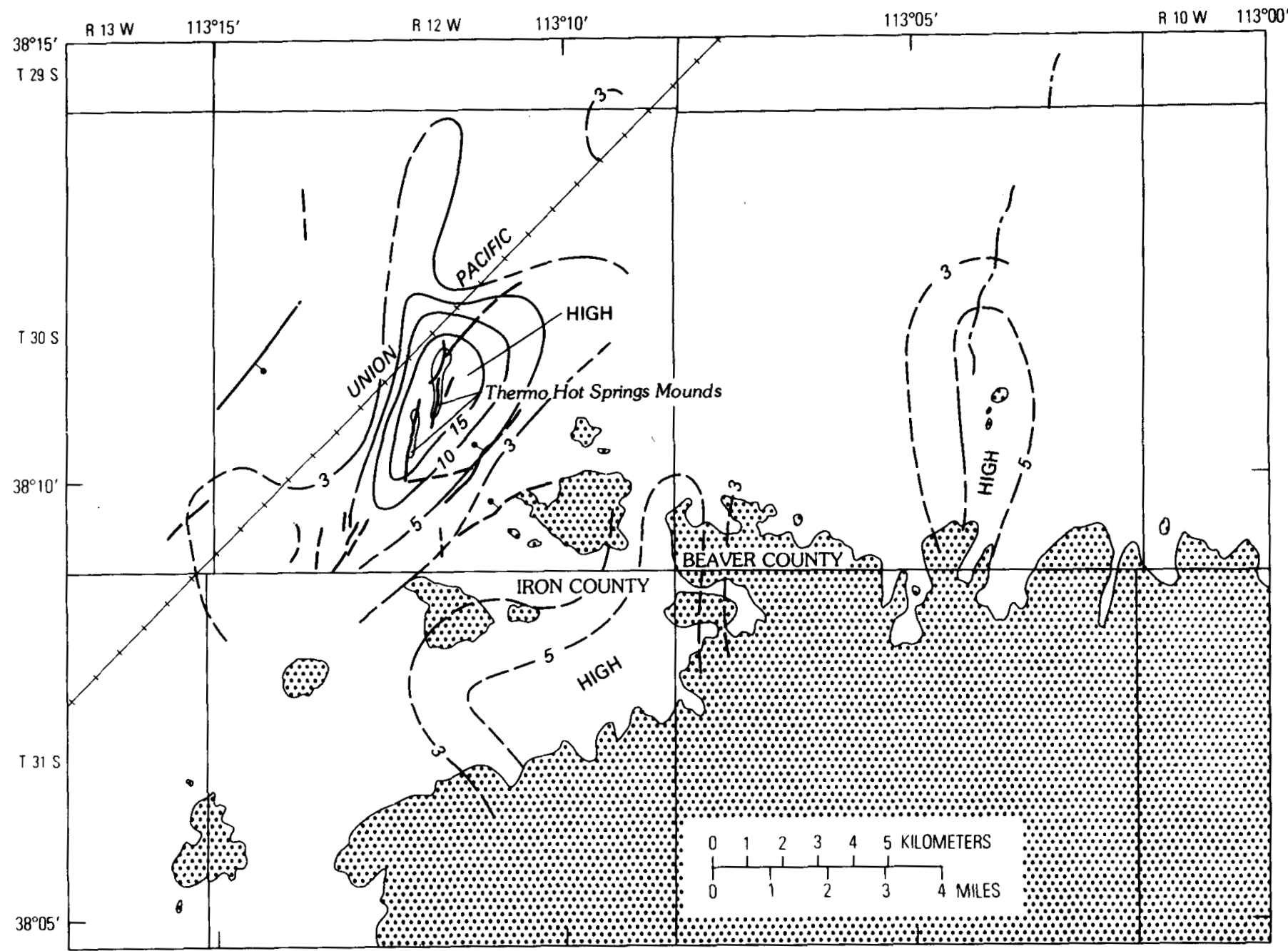

\section{EXPLANATION}

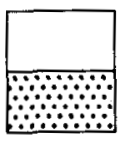

Alluvium-Mostly clay, silt, and sand

CONSOLIDATED ROCK-Mostly Tertiary and

Quaternary volcanic rocks

Contact

- Fault, dashed where approximately located; bar and ball on downthrown side

- Lineament observed on aerial photographs

LNE OF EQUAL HEAT FLOW-Dashed where approximately located. Units are

Figure 10.-Shallow conductive heat fow in the Thermo Hot Springs area. 
TABLE 7.-Evapotranspiration of mixed water from Thermo Hot Springs hydrothermal system

[1976 conditions. The combined and nonhydrothermal system discharge rates are based on research by Lee (1912), White (1932), Young and Blaney (1942), Houston (1950), Robinson (1965), and Harr and Price (1972) in other areas]

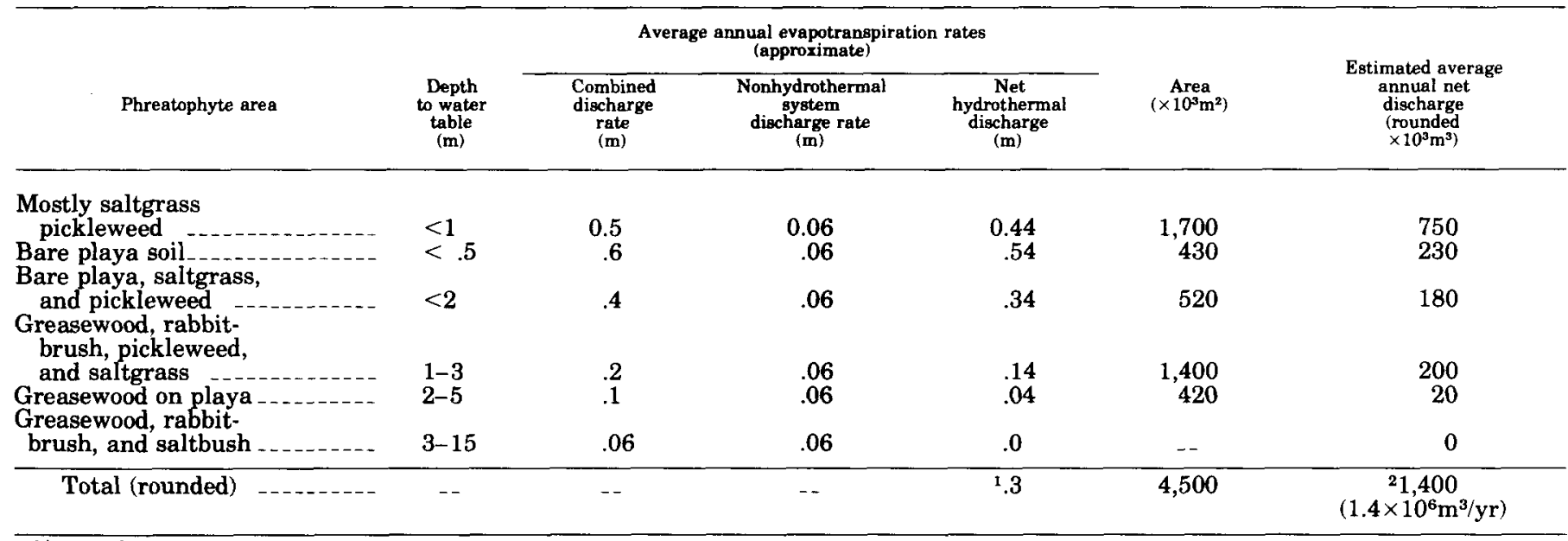

2Mixed thermal and nonthermal water.

Newcastle is on the floor of the Escalante Desert near the northwestern flank of the Pine Valley Mountains, a range composed mostly of Tertiary volcanic rocks (Hintze, 1963). The floor of the Escalante Desert is described by Crosby $(1973$, p. 28$)$ as the central region of a probable large caldera about $50 \mathrm{~km}$ in diameter. The rim of the caldera includes the surrounding mountains and Table Butte as shown in figure 11. Crosby gives no descriptions of the age or structure of the caldera in his report, but it is probably Tertiary.

The detailed distribution of young igneous rocks in this area is poorly known. Some basic igneous rocks less than 10,000 years old lie about 40 miles south of Newcastle, near the town of Veyo (Smith and Shaw, 1975, p. 82 , listed under Utah as Santa Clara). The reconnaissance geology of the area is shown in figure 12.

During December 1975, a newly drilled irrigation well (C-36-15)20bbd was test pumped at rates as high as $108 \mathrm{~L} / \mathrm{s}$. This well, owned by the Christensen Brothers of Newcastle, is $152 \mathrm{~m}$ deep, has a 40 -cm-diameter casing, and a static water level of about $43 \mathrm{~m}$. The water dis-

TABLE 8.-Estimated conductive heat discharge from Thermo Hot Springs hydrothermal system -alluvial area only

[Method B of Olmsted and others (1975, p. 67). The approximate area was determined from

\begin{tabular}{|c|c|c|c|}
\hline $\begin{array}{c}\text { Range in heat } \\
\text { flow units } \\
\text { (HFU) } \\
\left(\times 10^{-8} \mathrm{cal} / \mathrm{cm}^{2} / \mathrm{s}\right.\end{array}$ & $\begin{array}{l}\text { Approximate mean } \\
\text { heat flow } \\
\text { (HFU) }\end{array}$ & $\begin{array}{c}\text { Approximate } \\
\text { area } \\
\left(\mathbf{k m m}^{2}\right)\end{array}$ & $\begin{array}{c}\text { Heat discharge } \\
\left(\times 10^{3} \mathrm{cal} / \mathrm{s}\right) \\
\end{array}$ \\
\hline $\begin{array}{c}>15 \\
10-15 \\
5-10 \\
3-5\end{array}$ & $\begin{array}{ll} & 20 \\
\cdots & 12.5 \\
\cdots & 7.5 \\
\cdots & 4\end{array}$ & $\begin{array}{l}3.3 \\
3.3 \\
24 \\
50 \pm\end{array}$ & $\begin{array}{l}6.6 \\
4.1 \\
18 \\
20 \pm\end{array}$ \\
\hline $\begin{array}{l}\text { Total } \\
\text { (rounded) }\end{array}$ & $-\cdots$ & 80 & $\left(16 \times \frac{50}{10^{13} \mathrm{cal} / \mathrm{yr}}\right.$ \\
\hline
\end{tabular}

charged was boiling, about $95^{\circ} \mathrm{C}$ at land surface (altitude $=1,605 \pm \mathrm{m}$ ). A water sample was collected after 6 hours of pumping; the chemical analyses are given in table 9. The dissolved-solids concentration was only $1,120 \mathrm{mg} / \mathrm{L}$; the silica concentration was $99 \mathrm{mg} / \mathrm{L}$; and the dominant ions were sodium and sulfate. On January 20,1976 , after a period of several weeks during which the pump was idle, subsurface temperatures were measured in the well, resulting in the temperature profile in figure 13. The profile shows an alluvial aquifer containing hot water at a depth below land surface between 70 and $110 \mathrm{~m}$. Subsurface temperatures were lower above and below this aquifer. The maximum temperature recorded in the well was $107.8^{\circ} \mathrm{C}$; the bottomhole temperature was $4.1^{\circ} \mathrm{C}$ less. The well was pumped during the 1977 irrigation season; the water was cooled in two ponds and applied to cropland by sprinklers.

The estimated reservoir temperature for the hydrothermal system, based on chemical analysis and geothermometers, is $140^{\circ}-170^{\circ} \mathrm{C}$ in table 6 . The difference in the calculations in table 6 probably results from mixing of thermal and nonthermal waters. The maximum depth of circulation in the hydrothermal reservoir required to produce these temperatures is estimated to be 3-4 km, on the basis of regional heat flow of 2 HFU, thermal conductivity of the volcanic rocks that underlie the area of $5 \times 10^{-3} \mathrm{cal} / \mathrm{cm} / \mathrm{s}^{\circ} \mathrm{C}$, and an ambient land-surface temperature of about $14^{\circ} \mathrm{C}$. The calculation assumes the absence of a shallow magmatic-heat source. Using the graphic method of Truesdell and Fournier (1977) to estimate the mixing of thermal with nonthermal water, the hot-water component of the mixed water is estimated to be about 60 percent on the basis of data in table 6 . 
Shape and size of the hot-water body in the valley-fill (alluvial) aquifer are indicated in figures 12,14 , and 15, as well as the temperature profile shown in figure 13 .

The recharge area for the hydrothermal system is probably in the Pine Valley Mountains southeast of the town of Newcastle. The upward flow of thermal water is through a permeable range-front fault zone $1 \mathrm{~km}$ south- east of the thermal well (fig. 12). As hot water flows northward from the fault zone, its temperature declines owing to conductive-heat loss, mixing with cold, shallow-aquifer water, or both. Westward flow is relatively small compared to northward flow; this probably results from higher transmissivity toward the north than toward the west. Faulting and lithologic changes

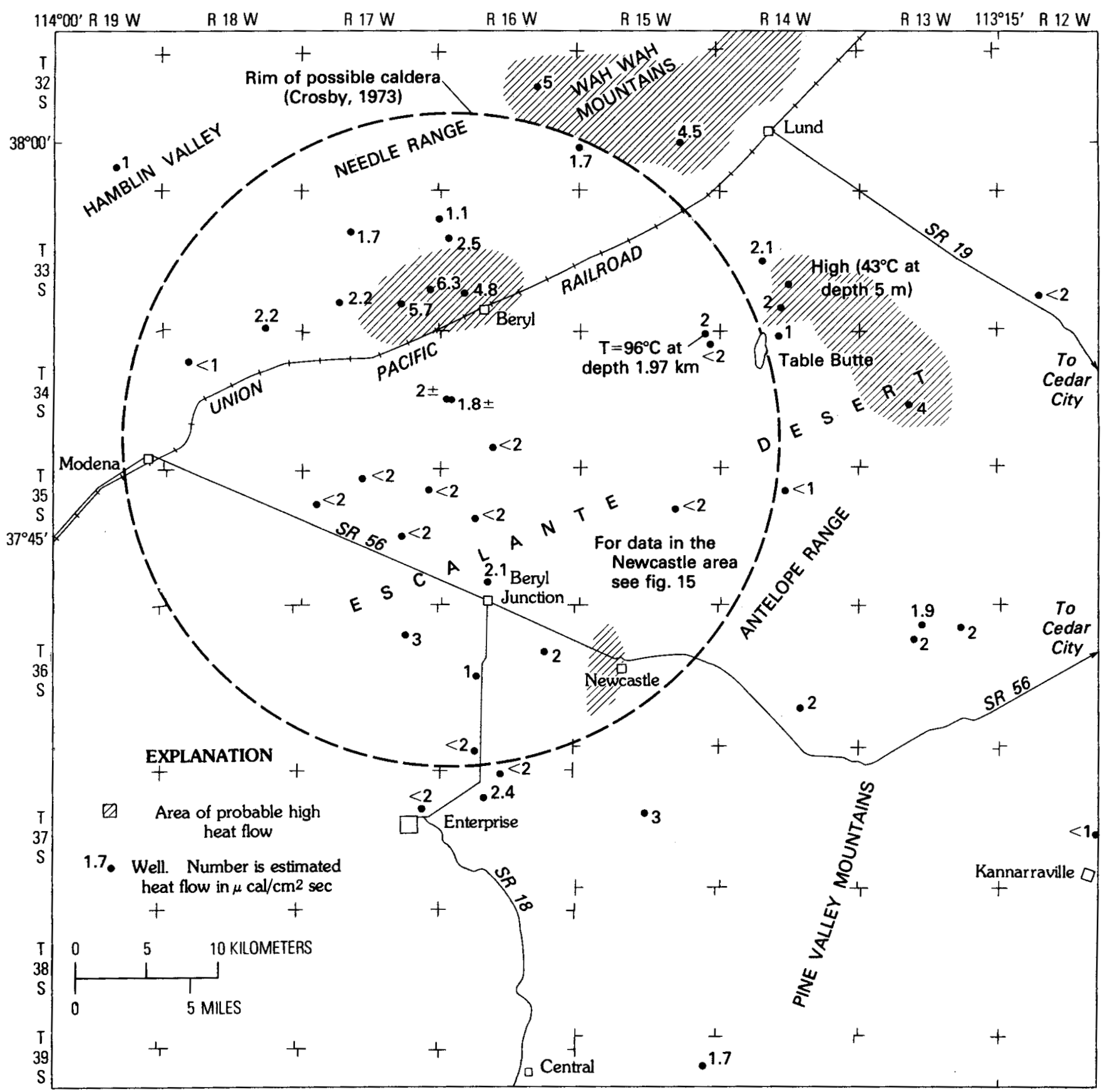

Base from U.S. Geological Survey $1: 250,000$ quadrangles

FigUre 11.-Estimated heat flow in southwestern Utah. 
TABLE 9.-Chemical analyses of water from Christensen brothers thermal well near Newcastle, Utah

[Location (C-36-15)20bbd. mg/L, miligrams per liter; $\mu \mathrm{g} / \mathrm{L}$, micrograms per liter; L/s, liters per second $\mu$ mho, micromhos; ${ }^{\circ} \mathrm{C}$, degrees Celsius]

\begin{tabular}{|c|c|c|c|}
\hline 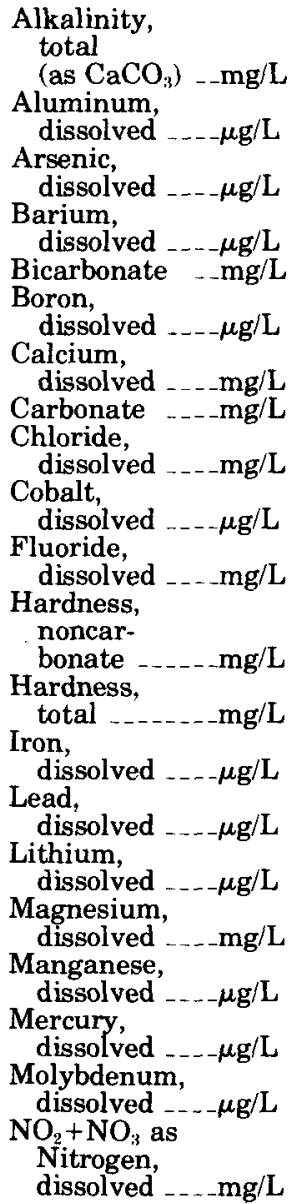 & $\begin{array}{r}300 \\
64\end{array}$ & 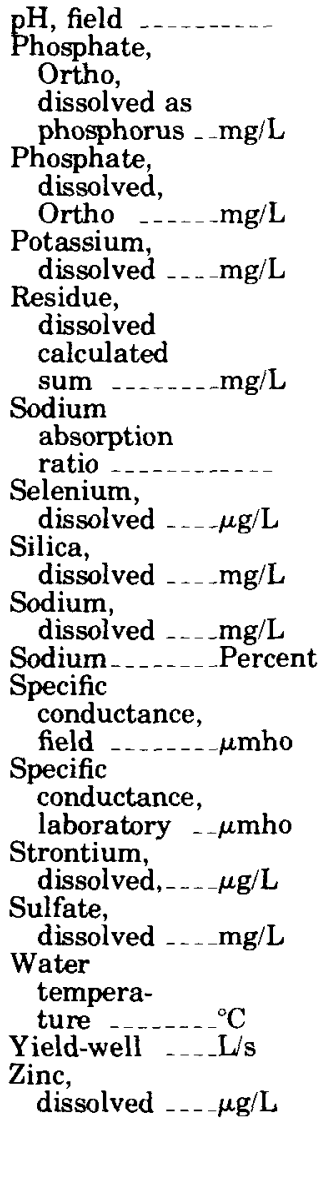 & $\begin{array}{r}270 \\
77\end{array}$ \\
\hline
\end{tabular}

to the west may be factors reducing westward flow. A helium-concentration survey (fig. 16) made by Denton (1976) produced a pattern generally similar to those in figures 14 and 15 near the fault zone that produces the hot water. He concludes that the helium is released from solution in the water as a result of either temperature or pressure decline while the water flows laterally in the shallow aquifer (E. H. Denton, oral commun., 1977).

Estimates of conductive-heat discharge to the land surface were made using method (B) of Olmsted and others (1975) (table 10) yielding identical results to $\operatorname{method}(\mathrm{A})$ of $7 \times 10^{13} \mathrm{cal} / \mathrm{yr}$. Calculations of $\operatorname{method}(\mathrm{A})$ are not presented. Essentially all the discharge from the hydrothermal system is by lateral ground-water flow from the fault zone. The flow rate was computed on the basis of an estimated conductive-heat discharge and a reservoir temperature of $170^{\circ} \mathrm{C}$. The estimated flow from the hydrothermal reservoir is about $0.4 \times 10^{6} \mathrm{~m}^{3} /$
TABLE 10.-Estimated conductive heat discharge from the Newcastle hydrothermal system -alluvial area only

[Method B of Olmsted and others (1975, p. 69). The approximate area was determined from figure 15]

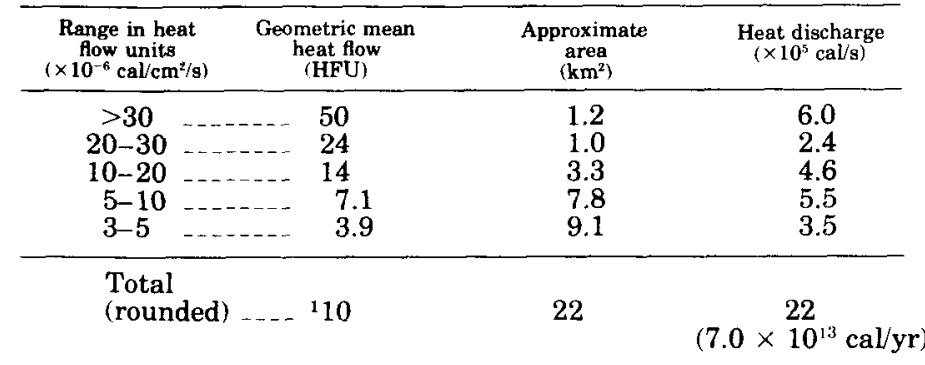

1 Average for area.

yr. The mixed water flows through the alluvium at an estimated rate of $0.7 \times 10^{6} \mathrm{~m}^{3} / \mathrm{yr}$.

Figure 11 shows estimated heat flow based on measured temperature gradients for many sites in and near the southeastern part of the Escalante Desert. In addition to the Newcastle area, high heat flow is shown west of Beryl and northwest of Lund. The Lund KGRA (fig. 1) is a few kilometers southeast of Lund, but no data were available that indicated high heat flow in the KGRA. Another area east of Table Butte may have high heat flow, but data are sparse. In the irrigated area between Enterprise and Beryl, both upward and downward flow of shallow ground water may be distorting conductive heat flow to the land surface.

\section{MONROE AND JOSEPH KGRA}

The Monroe and Joseph KGRA lies along the Sevier River in Sevier County, south-central Utah (fig. 1). The Pavant Range is to the northwest, the Sevier Plateau to the southeast. The towns of Joseph ([C-25-4]14) and Monroe ([C-25-3]8 and 17) are on the flood plain of the river. Joseph Hot Springs is about $2 \mathrm{~km}$ southeast of Joseph (fig.17). Monroe Hot Springs is on the east edge of Monroe; Red Hill Hot Spring is about $1 \mathrm{~km}$ farther northeast.

Tertiary volcanic rocks are dominant in the area. Monroe and Joseph are near the north edge of the Marysville volcanic area, where volcanism was extensive and prolonged from middle to late Tertiary. The volcanic rocks range in composition from basalt to rhyolite. Smith and Shaw $(1975$, p. 72) cite the age of the latest eruption, a rhyolite, as 20 million years. In the following discussion of the KGRA, Joseph Hot Springs will be described separately from Monroe and Red Hill Hot Springs because superficially it is a separate hydrothermal system. Monroe and Red Hill Hot Springs are parts of a single system.

Monroe and Red Hill Hot Springs flow from travertine mounds forming a bench at the western foot of the 


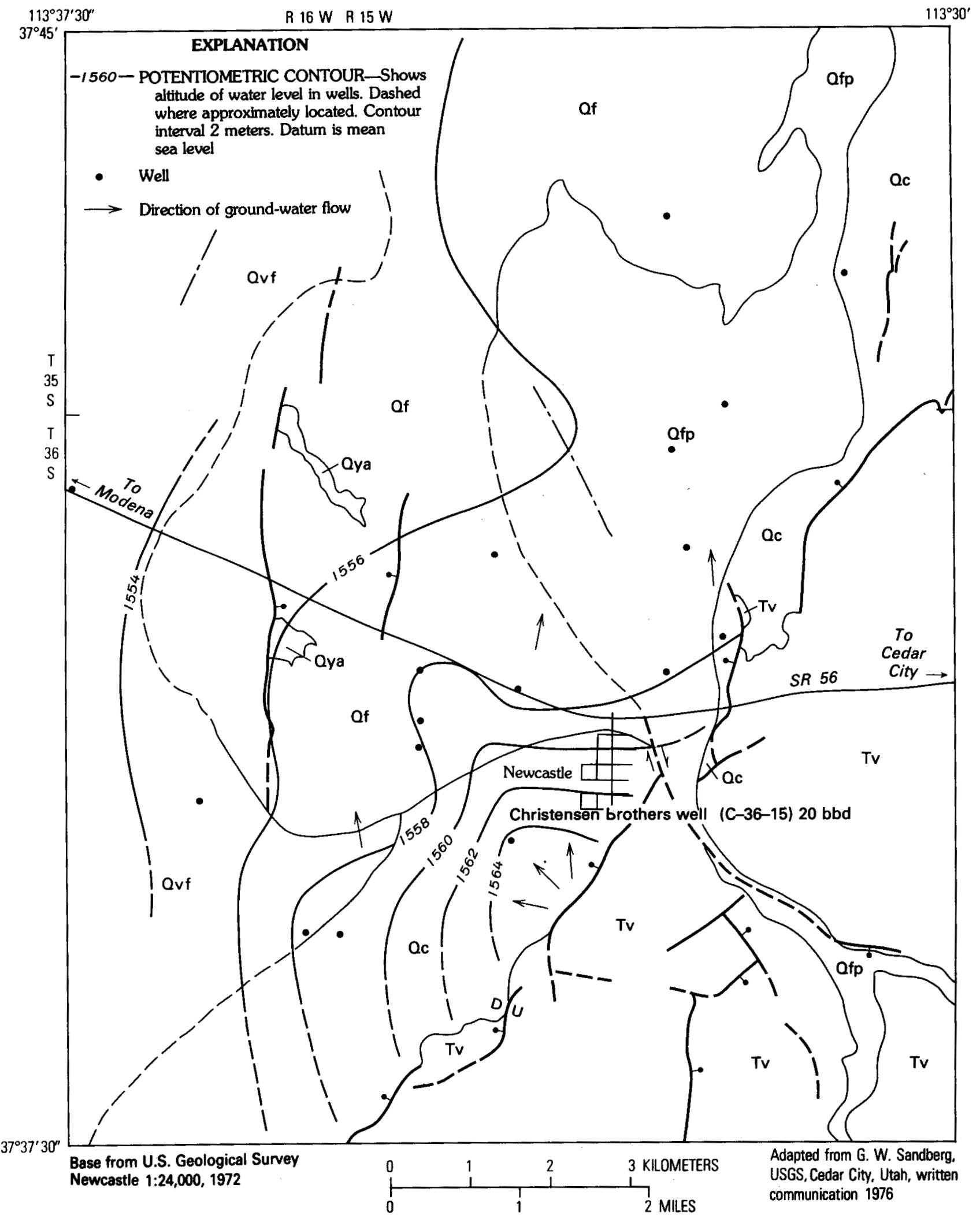

FIGURE 12.--Reconnaissance geologic map of the Newcastle area; and ground-water levels and direction of flow in the alluvium of the Newcastle area, spring 1976. 
Sevier Plateau. The springs are near the Sevier Fault, as shown on figure 18. Parry, Berson, and Miller (1976, p. 67) have mapped the consolidated-rock units near the spring. The principal units are Pliocene andesite and Miocene volcanic flows and tuffs. A flat valley floor west of the spring bench is underlain by alluvium of unknown thickness (fig. 18).

As part of this study, periodic measurements were made of all spring flow and water temperatures at Monroe and Red Hill Hot Springs (table 11). From March 1976 to March 1977 total flow varied from 11.0 to $21.1 \mathrm{~L} / \mathrm{s}$ and temperature ranged from $72^{\circ}-75^{\circ} \mathrm{C}$. The cause of the variation is not understood because data

\section{CORRELATION OF MAP UNITS}

\begin{tabular}{|c|c|c|c|c|}
\hline Oya & Ofp & & - Holocene & \\
\hline af & Qc & Ql & - Pleistocene & QUAIEKINARY \\
\hline Tv & & & & - TERTIARY \\
\hline
\end{tabular}

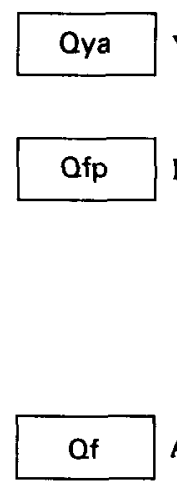

DESCRIPTION OF MAP UNITS

YOUNGER ALLUVIUM - Light-tan sandy silt and clay deposited in nearly horizontal, playalike areas. Land surface is hard and commonly has desiccation cracks. Deposit is thin and unsaturated.

FLOOD DEPOSITS OF PINTO CREEK-Light-tan to light-brown sandy silt deposited by Pinto Creek on its alluvial fan during frequent flood flows. Sand is mostly fine-grained quartz and volcanic-rock fragments. Material is mostly reworked Qf, described below. Forms moderately hard land surface with some desiccation cracks. Deposit is thin and generally unsaturated by ground water. Includes sand and gravel deposits along Pinto Creek in the mountains. ALLUVIAL-FAN DEPOSITS OF PINTO CREEK-Mostly light-brown fine- to mediumgrained silty sand and sandy silt deposited by Pinto Creek. Sand is mostly quartz and volcanic-rock fragments. Material is derived mostly from volcanic rocks of the Pinto Creek drainage basin in the Pine Valley Mountains. Forms moderately soft land surface. Depth to ground-water saturation ranges from $15 \mathrm{~m}$ to $30 \mathrm{~m}$ beneath the land surface.

Qc COLLUVIUM-Mostly medium- to dark-gray poorly sorted silt, sand, gravel, and boulders derived from the adjacent volcanic rocks of the mountains. Underlie a generally steep-sloping apron. Depth to ground-water saturation is generally greater than $\mathbf{3 0}$

Qvf $\mathrm{m}$.

LAKE BONNEVILLE SEDIMENTS-Mostly light-tan sandy silt. Largely undissected. Land surface generally hard. Depth to ground-water saturation is generally less than $30 \mathrm{~m}$.

TV VOLCANIC ROCKS-Generally dark-gray basalt; commonly vesicular.

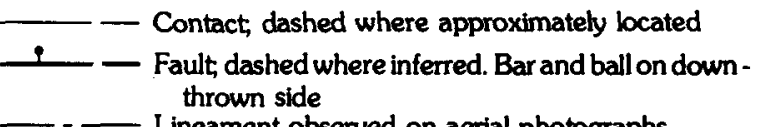
thrown side

Figure 12.-Continued. were collected for only 1 year, probably a period too short to establish trends and causes of the trends. The annual spring flow was about $0.5 \times 10^{6} \mathrm{~m}^{3}$. A small amount of additional water, about $0.05 \times 10^{6} \mathrm{~m}^{3} / \mathrm{yr}$, is estimated to be discharged by evapotranspiration by phreatophytes on the travertine bench. The flow of Red Hill Hot Spring, the largest spring in the complex, was at its maximum during October through March of the period of record. Generally, this was also the period of lower measured temperatures of the spring. This fact suggests that flow from the spring probably is a mixed water and that during the period of high flow the proportion of nonthermal water in the mixture is larger than during periods of low flow when the spring has higher temperatures. On the basis of the graphic method of estimating hot-water component in a mixed water (Truesdell and Fournier, 1977) and data in table 6, it is concluded that thermal water probably is mixing with an equal amount of nonthermal water between the point where it leaves the hydrothermal reservoir and the springs. The thermal-water component in the mixed water that is discharged by the springs was about $0.2 \times$ $10^{6} \mathrm{~m}^{3} / \mathrm{yr}$.

Samples of water from Red Hill and Monroe Hot Springs (Mundorff, 1970, p. 16) had sodium, sulfate, and chloride as the dominant ions as well as similar dissolved-solids concentrations of $2,630 \mathrm{mg} / \mathrm{L}$ and 2,700 $\mathrm{mg} / \mathrm{L}$, respectively. However, Red Hill had a silica concentration of $83 \mathrm{mg} / \mathrm{L}$ compared to only $51 \mathrm{mg} / \mathrm{L}$ for Monroe Hot Springs. Farther south on the Sevier fault, Johnson Warm Springs (fig. 17), whose water chemistry is much different than the other two springs, has dissolved solids of only $428 \mathrm{mg} / \mathrm{L}$.

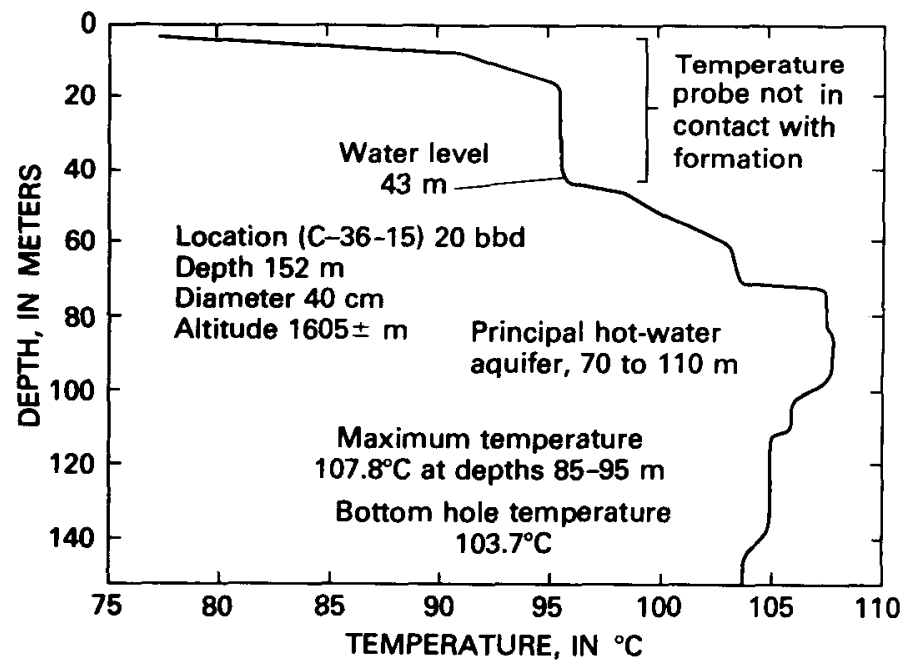

Figure 13.-Temperature profile of the Christensen Brothers thermal irrigation well near Newcastle, Utah. 


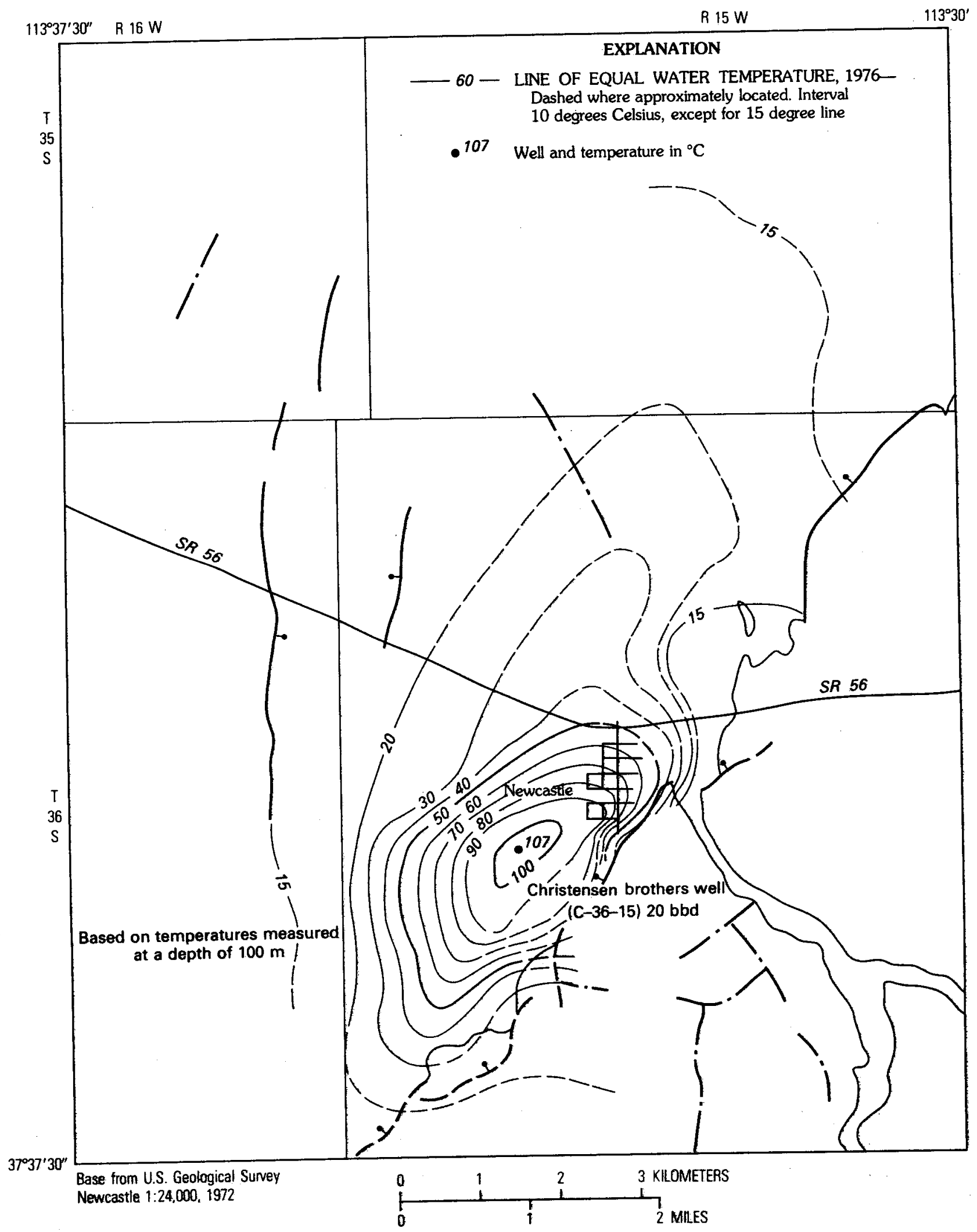

Figure 14.-Temperature at a depth of $100 \mathrm{~m}$ in the Newcastle area. 


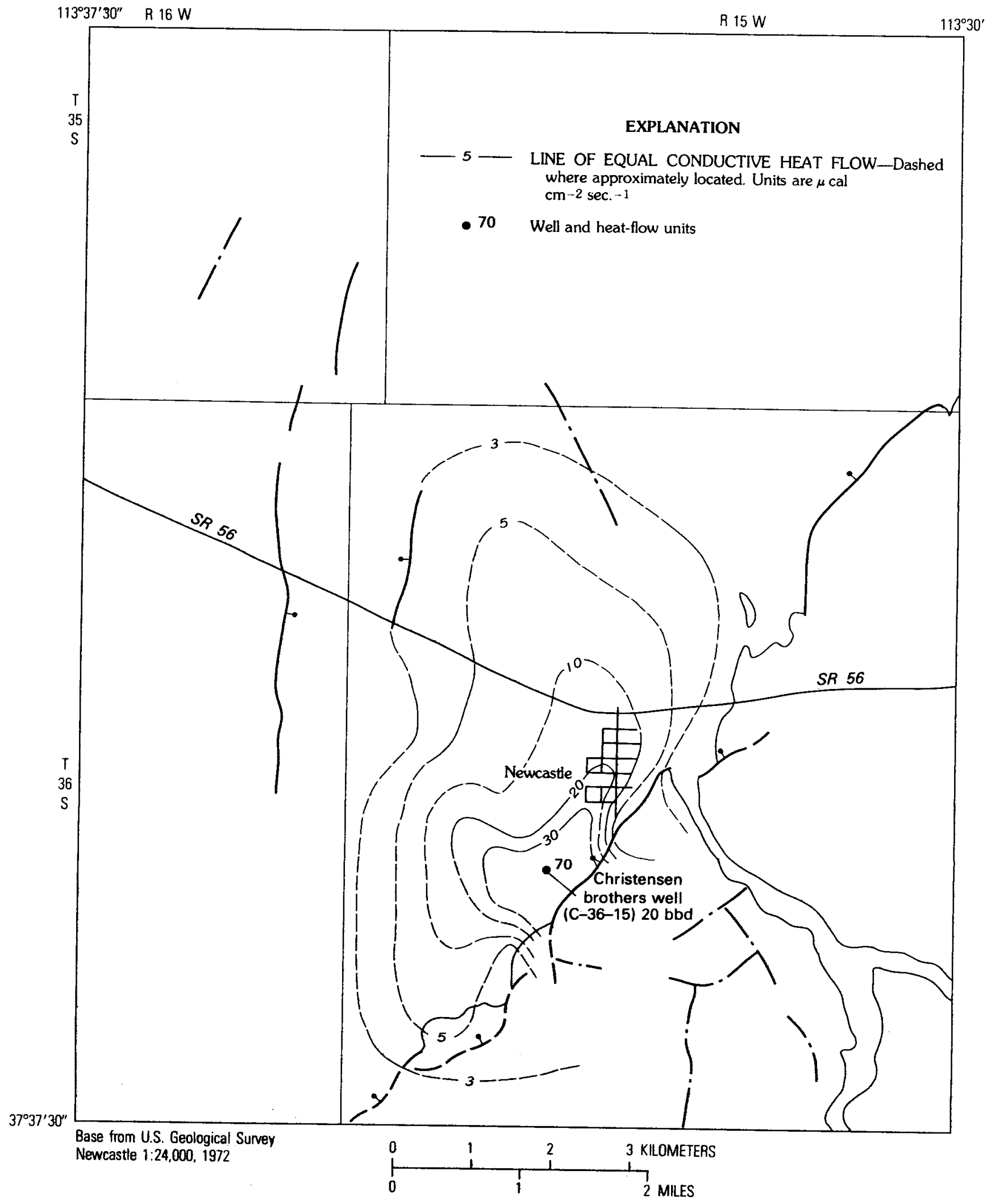

FiguRe 15.-Distribution of heat flow from the principal hot-water aquifer in the Newcastle area. 


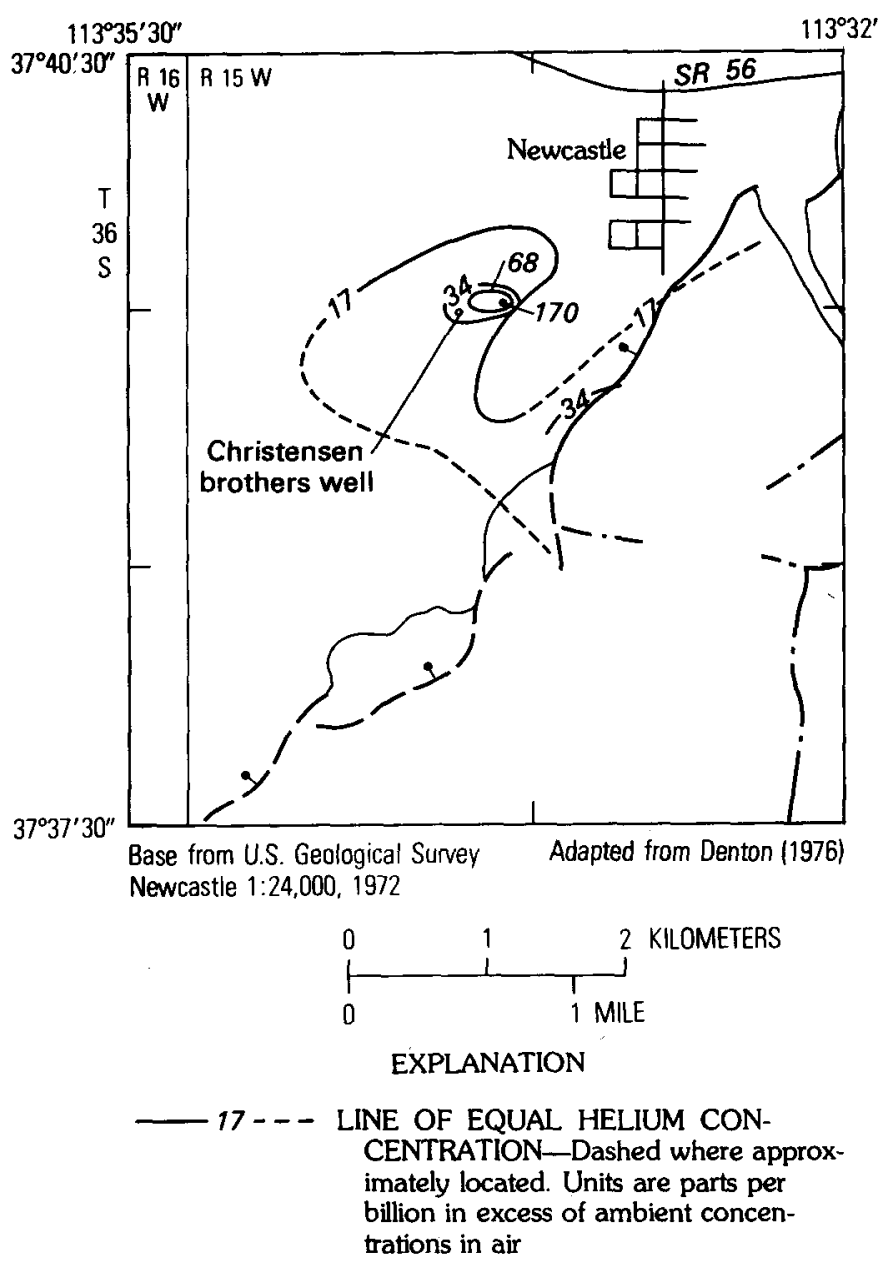

FIGURE 16. - Helium concentrations in the Newcastle area at a depth of $0.6 \mathrm{~m}$ below land surface.

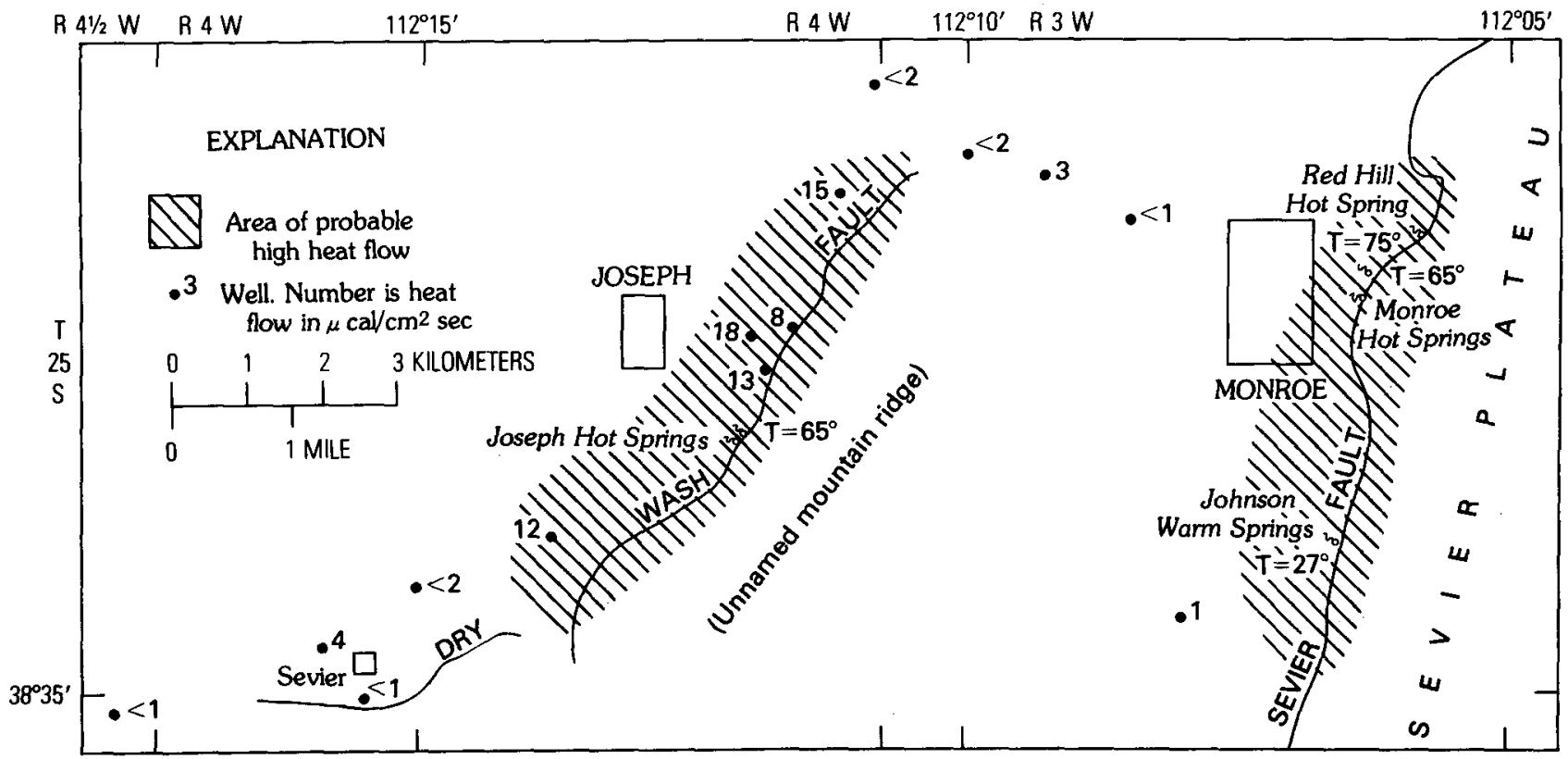
Monroe-Red Hill Hot Springs hydrothermal system is $100^{\circ}-160^{\circ} \mathrm{C}$, as determined from data in table 6 . The maximum depth of circulation to the hydrothermal reservoir, in order to produce these temperatures, is estimated to be about $2-4 \mathrm{~km}$ on the basis of a regional conductive heat flow of $2 \mathrm{HFU}$, thermal conductivity of the rock of about $5 \times 10^{-3} \mathrm{cal} / \mathrm{cm} / \mathrm{s}^{\circ} \mathrm{C}$, and an ambient land-surface temperature of $12^{\circ} \mathrm{C}$. The calculation assumes the absence of a shallow magmatic heat source.

The hydrothermal system probably is recharged on the Sevier Plateau, and thermal water circulates upward through a permeable fracture zone associated with the Sevier fault. In addition to the spring flow and evapotranspiration, discharge of mixed water may include an undetermined amount of lateral subsurface flow from the fault zone. Figure 17 shows a few data points for heat flow and the area of probable abovenormal regional heat flow confined to the vicinity of the fault.

The estimated heat discharge by spring flow and evapotranspiration is $3 \times 10^{13} \mathrm{cal} / \mathrm{yr}$. This estimate is based on a waterflow from the hydrothermal reservoir of a minimum of $0.2 \times 10^{6} \mathrm{~m}^{3} / \mathrm{yr}$ (50 percent of spring and evapotranspiration discharge) and an estimated maximum reservoir temperature of $160^{\circ} \mathrm{C}$. Lateral subsurface flow from the fault zone would discharge additional heat from the system.

Joseph Hot Springs is $\mathbf{8 ~} \mathbf{~ k m}$ southwest and across a low unnamed mountain ridge from Monroe Hot Springs (fig. 17). The general geologic and topographic settings are similar to those at Monroe Hot Springs. The springs flow from a travertine bench at the western foot of the $4 \mathrm{~W} \quad 112^{\circ} 10^{\prime} \quad \mathrm{R} 3 \mathrm{~W}$

The estimated reservoir temperature for the 
TABLE 11.-Measuned flow and tempenature of Monroe and Red Hill Hot Springs [Locations of sites shown on figure 18]

\begin{tabular}{|c|c|c|c|c|c|c|c|c|c|c|c|c|c|c|c|c|c|c|c|c|}
\hline \multirow{3}{*}{\multicolumn{2}{|c|}{ Date }} & \multicolumn{18}{|c|}{ Sites } & \multirow{3}{*}{$\begin{array}{l}\text { Total } \\
\text { flow } \\
(\mathrm{L} / \mathrm{s})\end{array}$} \\
\hline & & \multicolumn{2}{|c|}{ Red Hill } & \multicolumn{2}{|c|}{ Tunnel } & \multicolumn{2}{|c|}{1} & \multicolumn{2}{|c|}{2} & \multicolumn{2}{|c|}{3} & \multicolumn{2}{|c|}{4} & \multicolumn{2}{|c|}{5} & \multicolumn{2}{|c|}{6} & \multicolumn{2}{|c|}{7} & \\
\hline & & $\mathrm{L} / \mathrm{s}$ & ${ }^{\circ} \mathrm{C}$ & $\mathrm{L} / \mathrm{s}$ & ${ }^{\circ} \mathrm{C}$ & $L / B$ & ${ }^{\circ} \mathrm{C}$ & $\mathrm{L} / \mathrm{s}$ & ${ }^{\circ} \mathrm{C}$ & $L / s$ & ${ }^{\circ} \mathrm{C}$ & $\mathrm{L} / \mathrm{s}$ & ${ }^{\circ} \mathrm{C}$ & $L / \mathbf{s}$ & ${ }^{\circ} \mathrm{C}$ & L/s & ${ }^{\circ} \mathrm{C}$ & $\mathrm{L} / \mathrm{s}$ & ${ }^{\circ} \mathrm{C}$ & \\
\hline
\end{tabular}

ridge. The permeable zone through which hot water flows upward is the Dry Wash Fault zone. The narrow flood plain of the Sevier River is west of the fault. Table 12 lists the periodic measurements of all flow from Joseph Hot Springs. The flow ranges from 1.3 to $2.7 \mathrm{~L} / \mathrm{s}$ or an annual flow of about $0.07 \times 10^{6} \mathrm{~m}^{3} / \mathrm{yr}$. During the year that measurements were made, flow was generally declining for unknown reasons, but no pattern was observed in any relationship between flow and temperature as was observed at the Monroe-Red Hill Hot Springs complex. The maximum observed temperature of the springs was $65^{\circ} \mathrm{C}$. In addition to the spring flow, a small amount of water, about $0.01 \times 10^{6} \mathrm{~m}^{3} / \mathrm{yr}$, is estimated to be discharged by evapotranspiration of phreatophytes on the travertine bench.
Chemical analyses of samples from Joseph Hot Springs (Mundorff, 1970, p. 16) show that the highest silica concentration was $85 \mathrm{mg} / \mathrm{L}$. That sample had a dissolved-solids concentration of $5,150 \mathrm{mg} / \mathrm{L}$. The dominant ions were sodium and chloride. The estimated reservoir temperature (table 6) and depth of circulation of thermal waters are about the same as for the MonroeRed Hill Hot Springs system.

Recharge for the hydrothermal system may originate as precipitation in the nearby highlands or come from saturated alluvium underlying the Sevier River flood plain. During upward circulation from the hydrothermal reservoir through the permeable fault zone, the thermal water is estimated to $\mathrm{mix}$ with nonthermal water in the proportion 35-65 percent, respectively.

TABLE 12.-Measured flow and temperature of Joseph Hot Springs

[Sites 1-12 are progressively farther north, with I the southernmost and 12 the northernmost]

\begin{tabular}{|c|c|c|c|c|c|c|c|c|c|c|c|c|c|}
\hline \multirow{3}{*}{\multicolumn{2}{|c|}{ Date }} & \multicolumn{12}{|c|}{ Sites } \\
\hline & & \multicolumn{2}{|c|}{1} & \multicolumn{2}{|c|}{2} & \multicolumn{2}{|c|}{3} & \multicolumn{2}{|c|}{4} & \multicolumn{2}{|c|}{5} & \multicolumn{2}{|c|}{6} \\
\hline & & $\overline{\mathrm{L} / \mathrm{s}}$ & ${ }^{\circ} \mathrm{C}$ & $\mathrm{L}_{\mathrm{s}}$ & ${ }^{\circ} \mathrm{C}$ & $\overline{\mathrm{L} / \mathrm{s}}$ & ${ }^{\circ} \mathrm{C}$ & $\mathrm{L} / \mathrm{s}$ & ${ }^{\circ} \mathrm{C}$ & $\mathrm{L} / \mathrm{s}$ & ${ }^{\circ} \mathrm{C}$ & $\overline{\mathrm{L} / \mathrm{s}}$ & ${ }^{\circ} \mathrm{C}$ \\
\hline $\begin{array}{r}3-16-76 \\
4-14-76 \\
5-11-76 \\
6-7-76 \\
7-21-76 \\
8-26-76 \\
10-26-76 \\
12-27-76 \\
2-1-77 \\
3-26-77\end{array}$ & 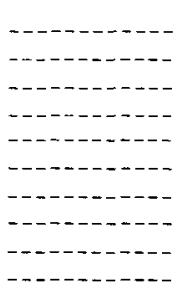 & $\begin{array}{r}0.8 \\
.4 \\
.2 \\
.2 \\
.2 \\
.2 \\
.2 \\
.2 \\
.2 \\
.2\end{array}$ & $\begin{array}{l}-58 \\
47 \\
56 \\
56 \\
56 \\
56 \\
52 \\
45 \\
44\end{array}$ & $\begin{array}{r}0.1 \\
<\quad .1 \\
.1 \\
.1 \\
.1 \\
.1 \\
<.1 \\
<.1 \\
<.1 \\
<.1\end{array}$ & $\begin{array}{l}-\overline{7}^{--} \\
47 \\
48 \\
47 \\
47.5 \\
48 \\
48 \\
46 \\
45\end{array}$ & $\begin{array}{r}<0.1 \\
.1 \\
.1 \\
.1 \\
.1 \\
.1 \\
<.1 \\
<.1 \\
<.1\end{array}$ & $\begin{array}{l}50 \\
49 \\
49 \\
50 \\
50 \\
49.5 \\
48 \\
48 \\
49\end{array}$ & $\begin{array}{r}0.1 \\
.1 \\
.2 \\
.2 \\
.2 \\
.2 \\
.2 \\
.1 \\
.1 \\
.1\end{array}$ & $\begin{array}{l}65 \\
65 \\
64 \\
64 \\
64.5 \\
64 \\
64 \\
62 \\
61.5\end{array}$ & $\begin{array}{r}0.3 \\
.3 \\
.3 \\
.2 \\
.3 \\
.3 \\
.3 \\
.3 \\
.4 \\
.2\end{array}$ & $\begin{array}{l}65 \\
64 \\
64 \\
64.5 \\
64.5 \\
64.5 \\
55 \\
57 \\
61\end{array}$ & $\begin{array}{r}0.5 \\
.5 \\
.6 \\
.7 \\
.6 \\
.7 \\
.7 \\
.4 \\
.4 \\
.2\end{array}$ & $\begin{array}{l}61 \\
60 \\
60 \\
60 \\
60 \\
60 \\
62 \\
59 \\
60\end{array}$ \\
\hline
\end{tabular}

\begin{tabular}{|c|c|c|c|c|c|c|c|c|c|c|c|c|c|c|c|}
\hline \multirow{3}{*}{ Date } & & \multicolumn{14}{|c|}{ Sites } \\
\hline & & \multicolumn{2}{|c|}{7} & \multicolumn{2}{|c|}{8} & & \multicolumn{2}{|c|}{$\mathbf{9}$} & \multicolumn{2}{|c|}{10} & \multicolumn{2}{|c|}{11} & \multicolumn{2}{|c|}{12} & \multirow{2}{*}{$\begin{array}{l}\text { Total } \\
\text { flow } \\
\text { (L/s) }\end{array}$} \\
\hline & & $L / 8$ & ${ }^{\circ} \mathrm{C}$ & $\mathrm{L} / \mathrm{s}$ & ${ }^{\circ} \mathrm{C}$ & & $\mathrm{L} / \mathrm{s}$ & ${ }^{\circ} \mathrm{C}$ & $\mathbf{L} / \mathbf{s}$ & ${ }^{\circ} \mathrm{C}$ & $\mathrm{L} / \mathrm{s}$ & ${ }^{\circ} \mathbf{C}$ & $\mathrm{L} / \mathrm{s}$ & ${ }^{\circ} \mathbf{C}$ & \\
\hline $\begin{array}{r}3-16-76 \\
4-14-76 \\
5-11-76 \\
6-7-76 \\
7-21-76 \\
8-26-76 \\
10-26-76 \\
12-27-76 \\
2-1-77 \\
3-26-77\end{array}$ & (1) & $\begin{array}{r}0.1 \\
.2 \\
.2 \\
.2 \\
.2 \\
.2 \\
.2 \\
<.1 \\
<.1 \\
<.1\end{array}$ & $\begin{array}{l}52 \\
47 \\
48 \\
47.5 \\
48 \\
47.5 \\
47 \\
45 \\
48\end{array}$ & $\begin{aligned} &<0.1 \\
& .1 \\
& .1 \\
&<.1 \\
&<.1 \\
&<.1 \\
&<.1 \\
&<.1 \\
&<.1 \\
&<.1 \\
&<.1\end{aligned}$ & $\begin{array}{l}61 \\
59.5 \\
61 \\
61 \\
60.5 \\
61 \\
60 \\
59 \\
58.5\end{array}$ & 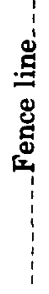 & $\begin{array}{r}0.1 \\
.2 \\
.2 \\
.2 \\
.2 \\
.2 \\
.2 \\
<.1 \\
.1 \\
.1\end{array}$ & $\begin{array}{l}59 \\
\mathbf{5 8} \\
\mathbf{5 9} \\
\mathbf{5 9} \\
\mathbf{6 0} \\
\mathbf{5 9} \\
\mathbf{5 8} \\
\mathbf{5 8} \\
\mathbf{5 0}\end{array}$ & $\begin{array}{r}0.4 \\
.4 \\
.3 \\
.2 \\
.2 \\
.2 \\
.2 \\
.5 \\
.3 \\
.3\end{array}$ & $\begin{array}{l}42 \\
43 \\
43 \\
42.5 \\
42.5 \\
43 \\
43 \\
41 \\
44\end{array}$ & $\begin{array}{r}0.2 \\
.2 \\
.2 \\
.2 \\
.2 \\
.2 \\
.2 \\
.2 \\
.2 \\
.2\end{array}$ & $\begin{array}{l}\mathbf{4 6} \\
\mathbf{5 9 . 5} \\
\mathbf{5 9} \\
\mathbf{5 9 . 5} \\
\mathbf{6 0} \\
\mathbf{5 9 . 5} \\
\mathbf{6 0} \\
\mathbf{5 9} \\
\mathbf{4 5}\end{array}$ & $\begin{array}{r}0.2 \\
.2 \\
.1 \\
.1 \\
.1 \\
.1 \\
.1 \\
.1 \\
.1 \\
.1\end{array}$ & $\begin{array}{l}37 \\
38.5 \\
38.5 \\
39 \\
38.5 \\
39 \\
38 \\
38 \\
33\end{array}$ & $\begin{array}{l}2.7 \\
2.7 \\
2.6 \\
2.4 \\
2.4 \\
2.4 \\
2.5 \\
1.8 \\
1.8 \\
1.3\end{array}$ \\
\hline
\end{tabular}


Therefore, only about one-third of the earlier reported rates of spring and evapotranspiration discharge would have circulated through the hydrothermal system. An additional unknown amount of thermal water is being discharged into the alluvium from the fault zone.

The heat-flow values on figure 17, ranging from 8 to $18 \mathrm{HFU}$, probably are the result of high temperature gradients in the shallow ground-water system. Beneath the alluvial aquifers containing this shallow lateral flow, conductive heat flow toward the land surface probably is much less, such as is illustrated by the tempei ature profile in the Christensen Brothers well near Newcastle (fig. 13).

The estimated heat discharge by spring flow and evapotranspiration is $0.3 \times 10^{13} \mathrm{cal} / \mathrm{yr}$ on the basis of a cooling of thermal water from a temperature as high as $170^{\circ} \mathrm{C}$ to an ambient land-surface temperature of $12^{\circ} \mathrm{C}$. Lateral subsurface flow of mixed water from the fault zone to alluvium would discharge additional heat from the system.

\section{CRATER HOT SPRINGS}

Crater Hot Springs, also known as Baker Hot Springs and Abraham Hot Springs, is about $30 \mathrm{~km}$ northwest of Delta, Utah (fig. 1), at (C-14-8)10S. The springs and Crater Bench, a nearby, young basalt flow, are on the northwestern part of the broad, nearly flat alluvial floor of the Sevier Desert. The springs flow from a low travertine and alluvial mound a few hundred meters east of the lava flow. The altitude of the land surface at the spring mound is about $1,410 \mathrm{~m}$ above sea level.

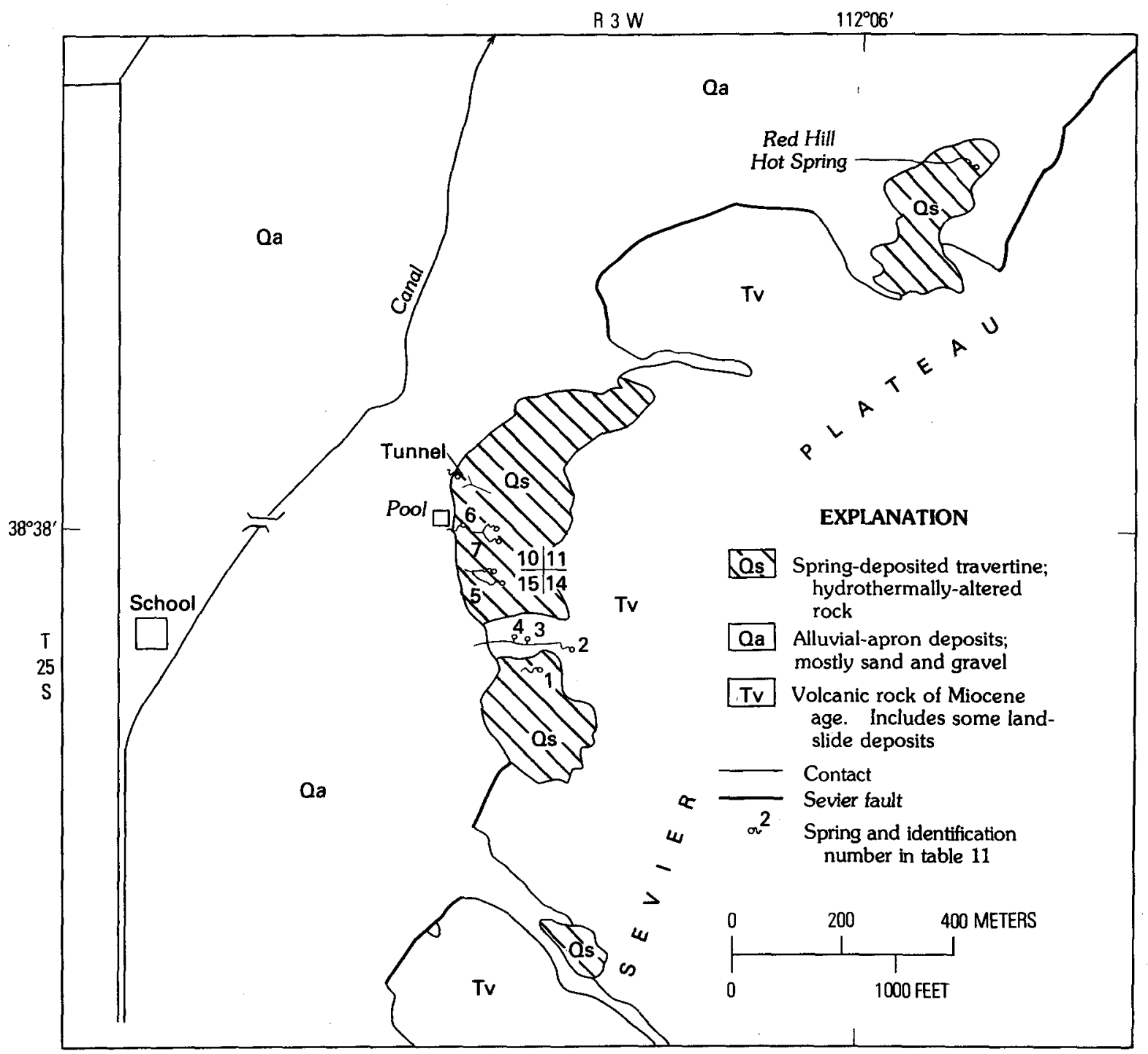

Base from aerial photographs: U.S. Geological Survey, 1953

Figure 18.-Surficial geology at Monroe and Red Hill Hot Springs. 
Crater Bench is generally oval in shape, $16 \mathrm{~km}$ by 10 $\mathrm{km}$. The high point on the bench is at the top of Fumarole Butte (fig. 19), the neck of the volcanic conduit, having an altitude of $1,609 \mathrm{~m}$. The butte takes its name from gas vents that were reported to have been active during historic time. The altitude of the surrounding area of the bench generally ranges from 1,460 to $1,520 \mathrm{~m}$ above sea level; therefore, the upper surface of the lava flow generally ranges from about 50 to $100 \mathrm{~m}$ higher than the springs. At the northeast end of the bench, rhyolite, possibly Pliocene in age, has been mapped by Galyardt and Rush (1979). The remainder of the bench is probably either Pleistocene $(<2-3$ million years old) or late Pliocene in age. The bench is cut by a series of northeast-trending normal faults.

Crater Bench lies along the south edge of an east-west line of three calderas (fig. 19) described by Shawe (1972). The last eruption of the calderas is reported to consist of late Tertiary and Quaternary(?) basalt and rhyolite. Silicic-rock ages as young as $3.4 \pm 0.2$ million years were reported by Shawe. Although the relation of a controlling fault of Crater Hot Springs to arcuate ring faults associated with magma-chamber roof collapse is unknown, the controlling faults and ring faults are proximal in location and age.

As part of the present study, the surface lithology of the Crater Hot Springs area was mapped (fig. 20). The vertical flow of hot water to the land surface is assumed to be through a fault-controlled permeable zone that generally underlies hot springs in the Basin and Range province. However, no fault cutting the spring mound could be located during geologic field mapping. A gravity map of the area (Smith, 1974) (fig. 20) shows a highgravity anomaly beneath the spring area that extends northwestward. The contour pattern is interpreted as possibly being caused by a shallow body of volcanic rock or hot-water deposits of relatively high density. The location of Smith's gravity anomaly suggests that any controlling fault for Crater Hot Springs may extend beneath Crater Bench and the spring area, as shown in figure 20.

Figure 21 is a generalized cross section of Crater Bench, based on Schlumberger resistivity soundings provided by A. A. R. Zohdy (written commun., 1975). The basalt flow is pictured as resting on top of alluvial valley fill; the depth to basement rock is about $1.1 \mathrm{~km}$.

An inventory was made of about 40 spring orifices (fig. 22). (See table 17.) The estimated spring flow was $90 \mathrm{~L} / \mathrm{s}$ during February 1976. Some additional water seeps to and ponds on the land surface. No accurate measurement of this seepage was possible because of lack of observable flow in channels. In the table, this seepage is estimated as half the observed flow or a maximum of 45 $\mathrm{L} / \mathrm{s}$, for a total of about $140 \mathrm{~L} / \mathrm{s}$. This total flow rate probably is slightly too high because some water was "counted" twice at orifice pools R1, R2, and R3 and perhaps elsewhere (fig. 22). Each of these three pools has two orifices-one yielding water, one receiving water.

Four sites of which flows were relatively large and accurate measurements could be made were selected for periodic discharge measurements. Nearly all flow from the springs is included in the periodic measurements (table 13). For example, on February 26, 1976, the flow in the four channels was $87 \mathrm{~L} / \mathrm{s}$, compared to a total flow of $90 \mathrm{~L} / \mathrm{s}$ as noted earlier during the same month. Flow was generally declining during this period, but no relation between flow rate and water temperature was observed. During the period of measurement, the flow rate averaged $69 \mathrm{~L} / \mathrm{s}$.

The largest single flow was from the main-drain orifice on the northeastern part of the mound (fig. 22). Flow was about 80 percent of the total channelized flow. The maximum observed temperature of Crater Hot Springs was $87^{\circ} \mathrm{C}$ (table 6 ).

According to Mundorff (1970, p. 14), the dominant ions are calcium, sulfate, and chloride. A water sample collected in 1958 had a silica concentration of $28 \mathrm{mg} / \mathrm{L}$ and a dissolved-solids concentration of only $1,440 \mathrm{mg} / \mathrm{L}$. However, these concentrations represent flow from an orifice having a temperature of only $43^{\circ} \mathrm{C}$, much less than the maximum. As a result, it is not known whether the sample analysis represents the hottest water.

The estimated temperature of the hydrothermal reservoir in table 6 is $110^{\circ}-140^{\circ} \mathrm{C}$. The computed depth of water circulation to the hydrothermal reservoir is 1.3$1.7 \mathrm{~km}$, or only about $200-600 \mathrm{~m}$ into the bedrock underlying the alluvial valley fill. This estimate is based on a regional heat flow of $2 \mathrm{HFU}$, a mean thermal conductivity of $2.7 \times 10^{-3} \mathrm{cal} / \mathrm{cm} / \mathrm{s}^{\circ} \mathrm{C}$, an ambient land-surface temperaure of $14^{\circ} \mathrm{C}$, and the estimated reservoir temperatures.

The hydrothermal system may be recharged by percolation of ground water from saturated alluvium or by infiltration of precipitation in the mountains, perhaps the mountains of the calderas to the north. Upflow from the reservoir presumably is along a fault. During the upflow, the thermal water mixes with nonthermal water in the proportion: 50 percent thermal water, 50 percent nonthermal water, as computed by a graphic method of Truesdell and Fournier (1977). The mixed water flows upward to Crater Hot Springs where it flows onto the surface and supports vegetation or evaporates. Additional mixed water seeps into the shallow alluvium in the general spring area and supports phreatophytes (fig. 23); their water consumption is summarized in table 14 using the same general procedure described for Thermo Hot Springs. The total evapotranspiration of 


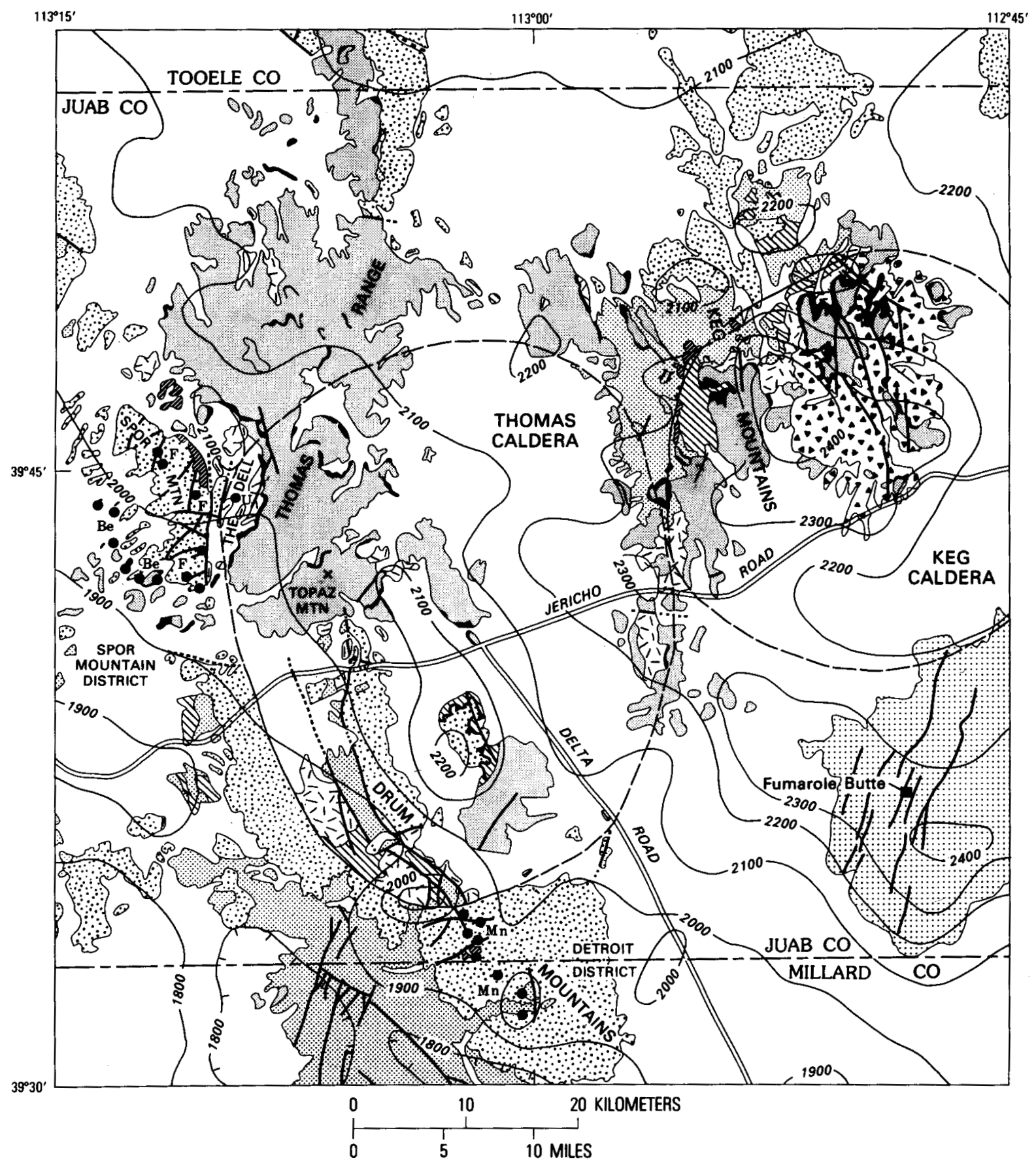

Figure 19.-Thomas, Keg, and Desert calderas, near Crater Hot Springs. 

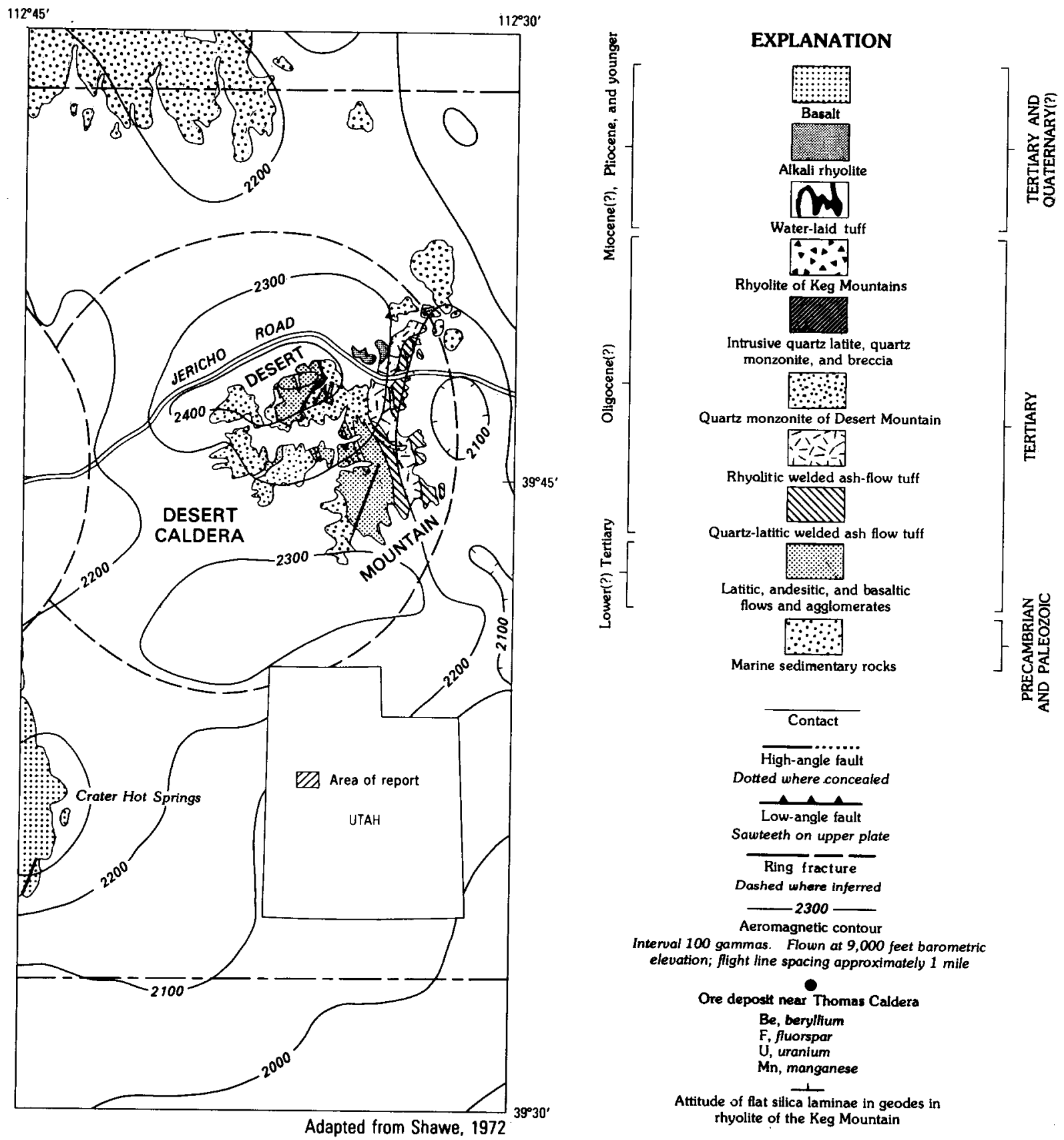

Figure 19.-Continued. 


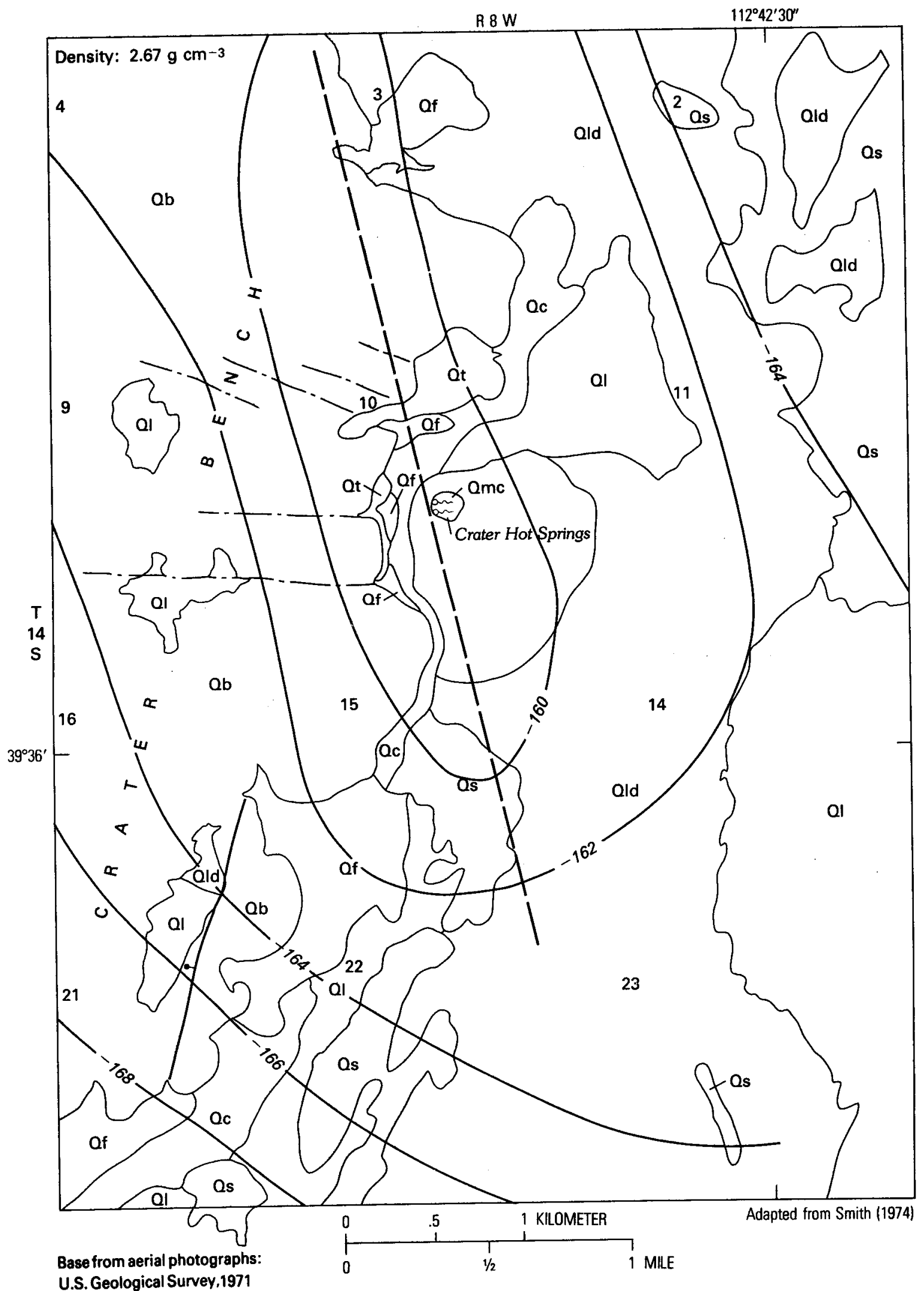

FIGURE 20.- Reconnaissance geologic map of the Crater Hot Springs area and a simple Bouguer gravity map of the Crater Hot Springs area. 


\section{CORRELATION OF MAP UNITS}

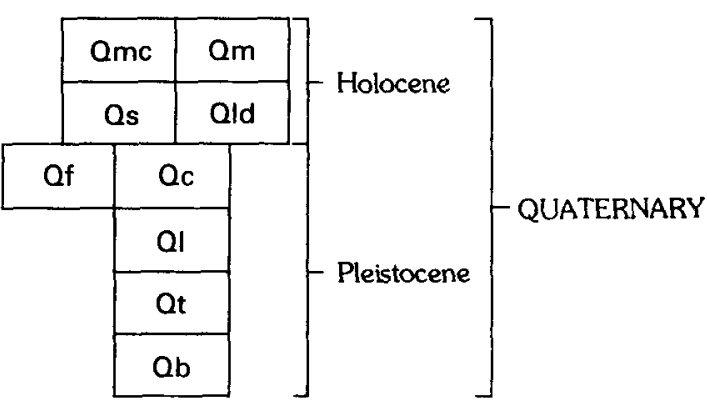

DESCRIPTION OF MAP UNITS

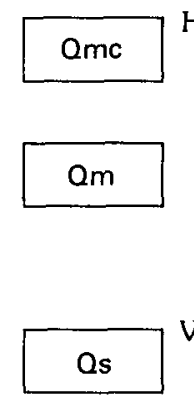

HYDROTHERMALLY-RELATED DEPOSITS

SPRING-MOUND CREST DEPOSITS-Mostly red silt and sand deposits rich in manganese oxide. Where deposits are dry, soil is fluffy. Travertine and travertine debris locally present

SPRING-MOUND DEPOSITS—Mostly light-gray silt and clay, commonly transported by wind and trapped by moist ground. Minor amounts of travertine and travertine debris on east slope of mound which has an average slope of about $20 \mathrm{~m} / \mathrm{km}$

VALLEY-FLOOR DEPOSITS

SAND DUNES-Mostly small dunes of windblown, light-yellowish-brown sand partly stabilized by greasewood. Direction of sand movement is northeast

Old

DISSECTED DEPOSITS OF LAKE BONNEVILLE-Light-yellowish-gray silt and clay. Dissected by local runoff and axial drainage southward on the valley floor

QI LAKE BONNEVILLE SEDIMENTS_-Undissected, light-yellowish-gray silt and clay underlying a valley floor having an average slope southwestward of less than $1 \mathrm{~m} / \mathrm{km}$. Also present on Crater Bench in relatively low areas

Qf

ALLUVIAL-APRON DEPOSITS

ALLUVIAL FAN DEPOSITS-Mostly basalt boulders and gravel in a matrix of light-yellowish-gray silt and sand below the mouth of small canyons cut into basalt flows of Crater Bench

Oc COLLUVIUM-Mixture of mostly light-yellowish-gray silt and clay with lesser amounts of slope-wash debris derived from local upslope materials. Underlies alluvial apron of intermediate slope

Qt

BASALT TALUS-Angular basalt blocks eroded from Crater Bench and underlie irregular, steep slopes on the flank of the Bench

CONSOLIDATED ROCKS

FUMAROLE BUTTE LAVA FLOWS-Black vesicular to massive basalt forming Crater Bench. Mostly large, angular blocks. Bench extends $30 \mathrm{~m}$ to $60 \mathrm{~m}$ higher than adjacent valley floor

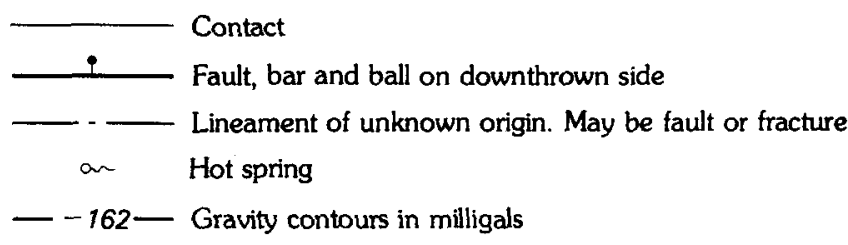

Figure 20.-Continued. mixed water is estimated to be $5 \times 10^{6} \mathrm{~m}^{3} / \mathrm{yr}$; this sum is equal to a continuous flow of $160 \mathrm{~L} / \mathrm{s}$. Additional water of unknown volume flows laterally from the area to be discharged elsewhere. On the basis of the evapotranspiration estimate above, the estimate that 50 percent of the mixed water is thermal water, a reservoir temperature of $140^{\circ} \mathrm{C}$ and an ambient land-surface temperature of $14^{\circ} \mathrm{C}$, the convective heat discharge is $36 \times 10^{13} \mathrm{cal} /$ yr.

Heat-flow estimates made for four water wells near Crater Hot Springs are shown on figure 24. The highest heat flow was $2.8 \mathrm{HFU}$, only slightly higher than the regional heat flow.

\section{NAVAJO LAKE KGRA}

Navajo Lake KGRA is on the Markagunt Plateau, about $30 \mathrm{~km}$ southeast of Cedar City in southwestern Utah (fig. 1). The Markagunt Plateau, part of the Colorado Plateaus, is a horst bounded by two major fault systems - the Hurricane fault zone on the northwest and the Sevier fault on the southeast. The width of the plateau near the KGRA is about $60 \mathrm{~km}$. The Navajo Lake KGRA has an area of only $10 \mathrm{~km}^{2}$ (table 2). It was designated solely because of overlapping lease application on Federal land, as is required by law.

Most of the rocks exposed at the surface are Tertiary limestones (Wasatch Formation) and volcanic rocks including highly permeable Quaternary basaltic flows. Beneath these units is a thick sequence of mostly Mesozoic and older sedimentary rock, of which sandstone is the most common (Hintze, 1963). Silicic lavas were erupted, but they are generally older than the basaltic lavas. Smith and Shaw $(1975$, p. 82$)$ list the largely unvegetated Markagunt basalt field as less than 10,000 years old.

No hot springs have been found in the Navajo Lake area. A well drilled at (C-36-7)33, about $10 \mathrm{~km}$ northeast of the KGRA had a reported temperature of drilling mud returning in the bore to land surface of $43^{\circ} \mathrm{C}$ with a drilling depth of $1,862 \mathrm{~m}$. This mud temperature could be produced with a heat flow of less than 2 HFU. As a result, the only possible indicator of geothermal potential is the very young basaltic flows.

\section{MEADOW AND HATTON HOT SPRINGS}

Meadow and Hatton Hot Springs are $18 \mathrm{~km}$ southwest of Fillmore (fig. 1) and a few kilometers north of the Cove Fort-Sulphurdale KGRA (fig. 1) in southwestern Utah. The springs are at (C-22-6)27ddS and (C-226)35ddS, respectively, on a low alluvial spring mount in Pavant Valley, a few kilometers west of the Pavant 


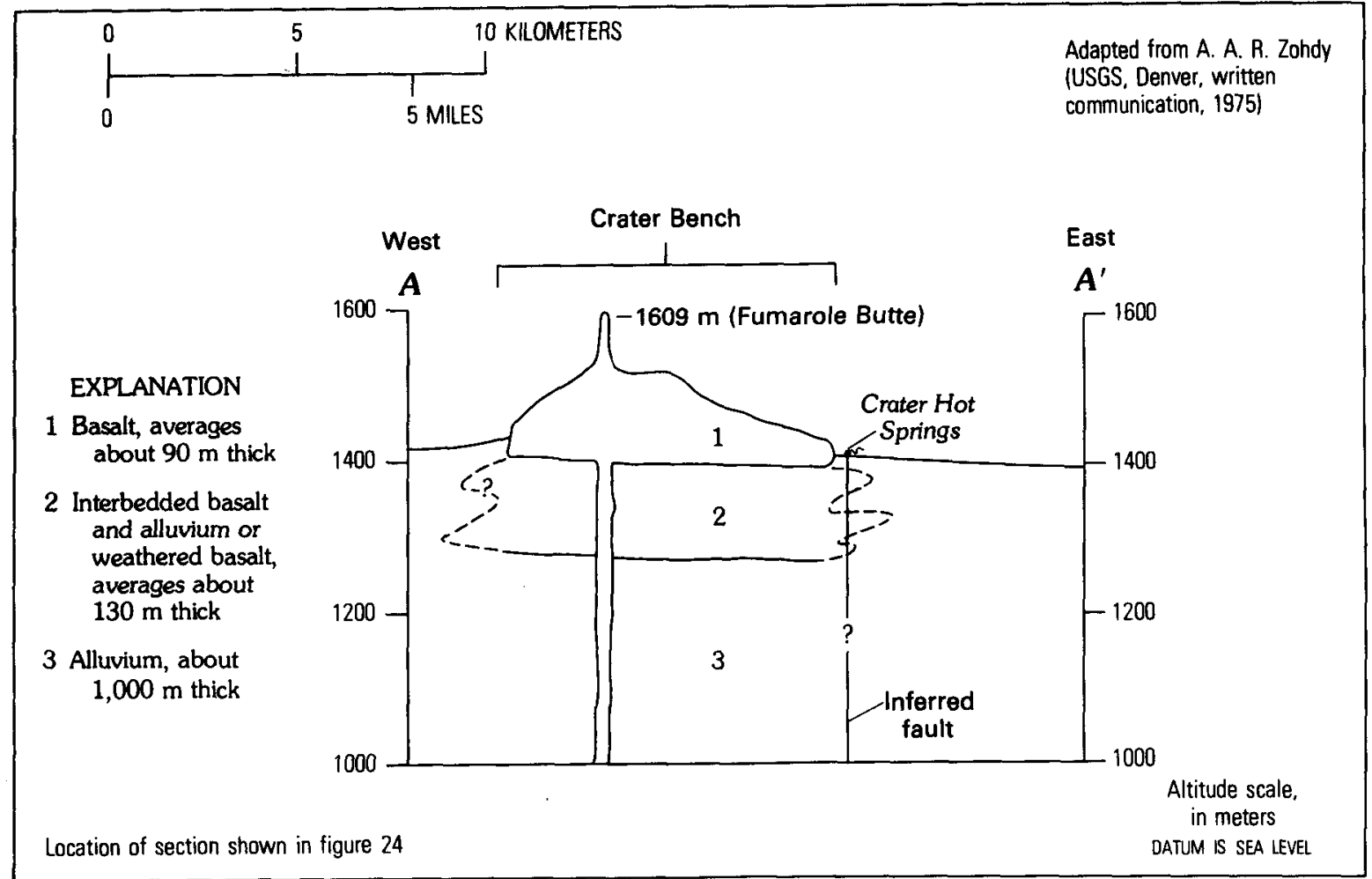

FiguRE 21.-Generalized cross section of Crater Bench.

Range. Underlying the alluvium of the spring area, volcanic rocks may be as shallow as $30 \mathrm{~m}$ from the land surface.

The Pavant Range has Paleozoic and Mesozoic quartzite and other sedimentary rocks thrust westward over Navajo Sandstone of Triassic (?) and Jurassic age (Hintze, 1963). North, west, and south of the springs, upper Tertiary and Quaternary basalt and basaltic andesite flows form low hills. A basaltic flow about 13 kilometers north of Hatton Hot Spring has been dated as less than 10,000 years old by Smith and Shaw (1975, p. 82, Ice Springs field).
Lithologic units are shown in figure 25. The most prominent geologic and topographic feature in the area is the spring-deposited travertine ridge at Hatton Hot Spring. The ridge is about $2 \mathrm{~km}$ long and rises perhaps $20 \mathrm{~m}$ above the general land surface. The shape and orientation of the ridge suggests fault control for the deposit-producing springs. Extending outward from the ridge is the very low alluvial spring mound (fig. 25) that is marked by many north-trending lineaments that may be faults. Travertine deposits at Meadow Hot Spring are small in volume, encircling the spring pool at the general land surface.

TABLE 13-Measured flow and temperature of Crater Hot Springs [Figure 22 shows locations of Spring E2, Spring R2, and the main-drain orifice. The Southwest ditch was measured south of Springs D1-D10 (table 17) and about $3 \mathrm{~m}$ northeast of concrete pools]

\begin{tabular}{|c|c|c|c|c|c|c|c|c|c|}
\hline \multirow{2}{*}{\multicolumn{2}{|c|}{ Date }} & \multicolumn{2}{|c|}{ Spring E2 } & \multicolumn{2}{|c|}{ Spring R2 } & \multicolumn{2}{|c|}{ Main-drain orifice } & \multicolumn{2}{|c|}{ Southwest ditch } \\
\hline & & $\begin{array}{c}\text { Flow } \\
(\mathbf{L} / \mathbf{s})\end{array}$ & $\begin{array}{c}\text { Temperature } \\
\text { ('C) }\end{array}$ & $\begin{array}{c}\text { Flow } \\
(\mathrm{L} / \mathrm{s})\end{array}$ & $\begin{array}{c}\text { Temperature } \\
\left({ }^{\circ} \mathrm{C}\right)\end{array}$ & $\begin{array}{c}\text { Flow } \\
(\mathrm{L} / \mathrm{s})\end{array}$ & $\begin{array}{c}\text { Temperature } \\
\left({ }^{\circ} \mathrm{C}\right)\end{array}$ & $\begin{array}{l}\begin{array}{c}\text { Flow } \\
\text { (L/s) }\end{array} \\
\end{array}$ & $\begin{array}{c}\text { Temperature } \\
\text { ('C) }\end{array}$ \\
\hline $\begin{array}{r}2-26-76 \\
4-8-76 \\
5-19-76 \\
6-7-76 \\
7-23-76 \\
9-2-76 \\
10-13-76 \\
11-15-76 \\
12-30-76 \\
2-3-77 \\
3-19-77\end{array}$ & (1) & $\begin{array}{l}4.8 \\
3.7 \\
4.5 \\
3.6 \\
-7.8 \\
3.9 \\
7.1 \\
4.3 \\
5.1 \\
3.1\end{array}$ & $\begin{array}{l}65 \\
6 \overline{6} \\
66 \\
6-- \\
65 \\
64.5 \\
68 \\
64 \\
65\end{array}$ & $\begin{array}{r}3.1 \\
4.5 \\
.3 \\
.6 \\
.0 \\
.0 \\
1.1 \\
1.4 \\
3.9 \\
1.9 \\
1.4\end{array}$ & $\begin{array}{l}70 \\
7 \overline{74} \\
76 \\
-- \\
6 \overline{9.5} \\
69 \\
67 \\
70 \\
69.5\end{array}$ & $\begin{array}{l}72.5 \\
73.6 \\
52.1 \\
52.9 \\
60.8 \\
52.3 \\
51.8 \\
51.5 \\
50.5 \\
46.2 \\
58.1\end{array}$ & $\begin{array}{l}52 \\
\overline{59} \\
60 \\
\overline{61} \\
65 \\
55 \\
55 \\
54 \\
54\end{array}$ & $\begin{array}{l}7.4 \\
8.4 \\
6.5 \\
6.4 \\
6.5 \\
5.9 \\
6.0 \\
6.0 \\
6.0 \\
5.2 \\
6.0\end{array}$ & $\begin{array}{l}-- \\
\overline{74} \\
78 \\
\overline{70} \\
70 \\
68 \\
68 \\
72 \\
70\end{array}$ \\
\hline
\end{tabular}




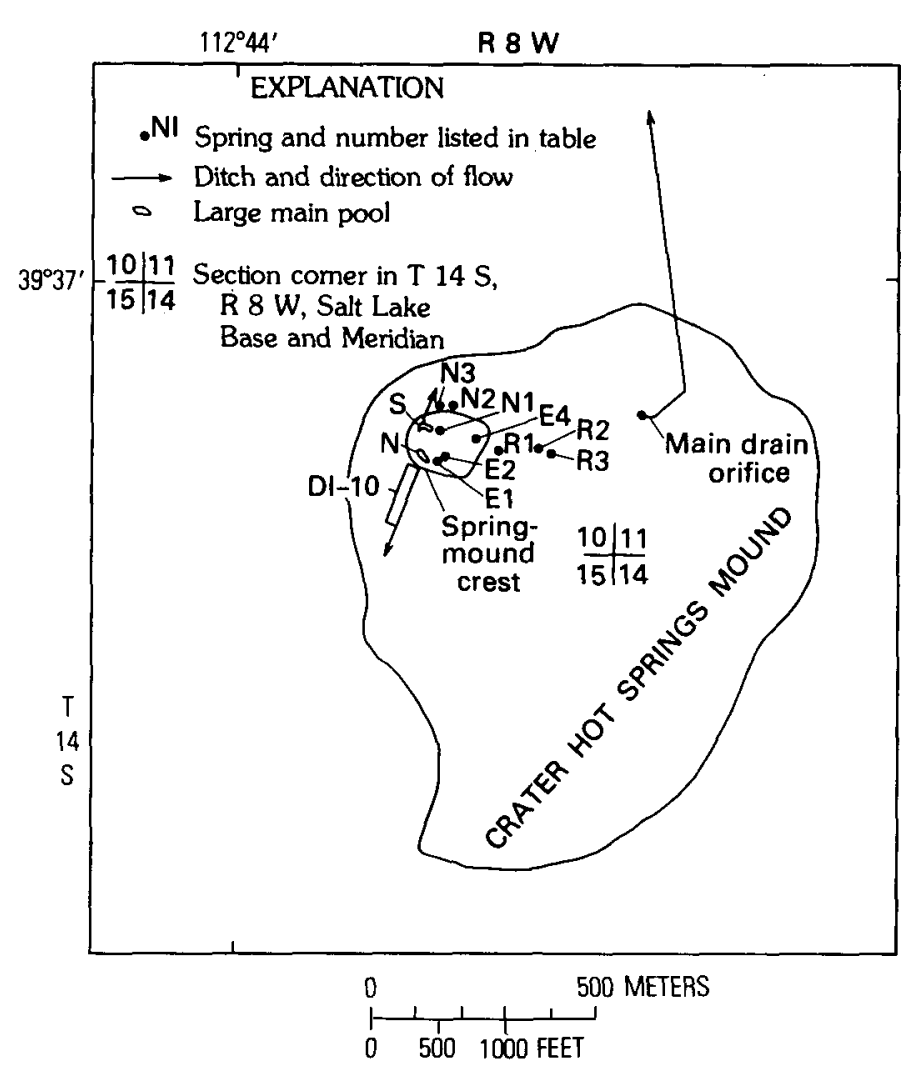

FIGURE 22.-Spring orifices and pools on the mound of Crater Hot Springs.

The observed discharge from both Meadow and Hatton Hot Springs was less than $1 \mathrm{~L} / \mathrm{s}$ in the summer of 1976. Mundorff $(1970$, p. 40$)$ reports a flow of about $4 \mathrm{~L} / \mathrm{s}$ from Meadow Hot Spring and an absence of flow at Hatton Hot Spring during several recent years. The temperatures at these two springs, and those at other nearby sites, are shown in figure 26 . The highest temperature, $67^{\circ} \mathrm{C}$, was measured in a $27-\mathrm{m}$ well a few tens of meters north of Hatton Hot Spring. The $67^{\circ} \mathrm{C}$ temperature was measured from a depth of $5 \mathrm{~m}$ to total depth.
Hatton Hot Spring had a temperature of $36^{\circ} \mathrm{C}$ at that time; Meadow Hot Spring pool was $30^{\circ} \mathrm{C}$. Agricultural wells, $3 \mathrm{~km}$ and more to the east of the spring mound, not shown on figure 26 , generally have discharge temperatures of $13^{\circ} \mathrm{C}$.

Mundorff (1970, p. 16) has published several chemical analyses for both Meadow and Hatton Hot Springs. He reports water temperatures for Meadow Hot Spring ranging from $29^{\circ} \mathrm{C}$ to $41^{\circ} \mathrm{C}$. A sample collected in 1967 had a silica concentration of $47 \mathrm{mg} / \mathrm{L}$ and dissolved solids of $4,900 \mathrm{mg} / \mathrm{L}$. The principal ions were sodium and chloride. The Hatton Hot Spring sample was collected at a temperature of $38^{\circ} \mathrm{C}$, had a silica concentration of 44 $\mathrm{mg} / \mathrm{L}$, had dissolved solids of $4,670 \mathrm{mg} / \mathrm{L}$, and had ion concentrations very similar to those of Meadow Hot Spring.

The temperature of the hydrothermal reservoir, estimated with geothermometers, is possibly in the range of $70^{\circ} \mathrm{C}$ to $120^{\circ} \mathrm{C}$ (table 6). The maximum depth of circulation required to produce the estimated reservoir temperatures with normal regional heat flow is about 2-3 $\mathrm{km}$; this estimate is based on a mean thermal conductivity of the underlying rock and thin alluvium of $5 \times 10^{-3}$ $\mathrm{cal} / \mathrm{cm} / \mathrm{s}^{\circ} \mathrm{C}$ and an ambient land-surface temperature of $12^{\circ} \mathrm{C}$. The calculations assume the absence of a shallow magma heat source.

Recharge to the hydrothermal system probably results from percoiation downward from saturated alluvium of the area or from infiltration of precipitation in the Pavant Range. During upward flow, the thermal water may be mixing with nonthermal water in the proportion of about 40 percent thermal water and 60 percent nonthermal water, as estimated by the graphic method of Truesdale and Fournier (1977). The mixed water is discharged by the springs, by evapotranspiration of pheatophytes on the spring mound, and by subsurface flow from the mound area principally to the north and west. The observed spring flow in 1976 was small, but the evapotranspiration was large. Much of

TABLE 14.-Evapotranspiration of ground water from Crater Hot Springs hydrothermal system [1975 conditions. The combined and nonhydrothermal system discharge rates are based on research by Loe (1912), White (1932), Young and Blaney (1942), Houston (1950), Robinson (1965),
and Harr and Price (1972) in other areas]

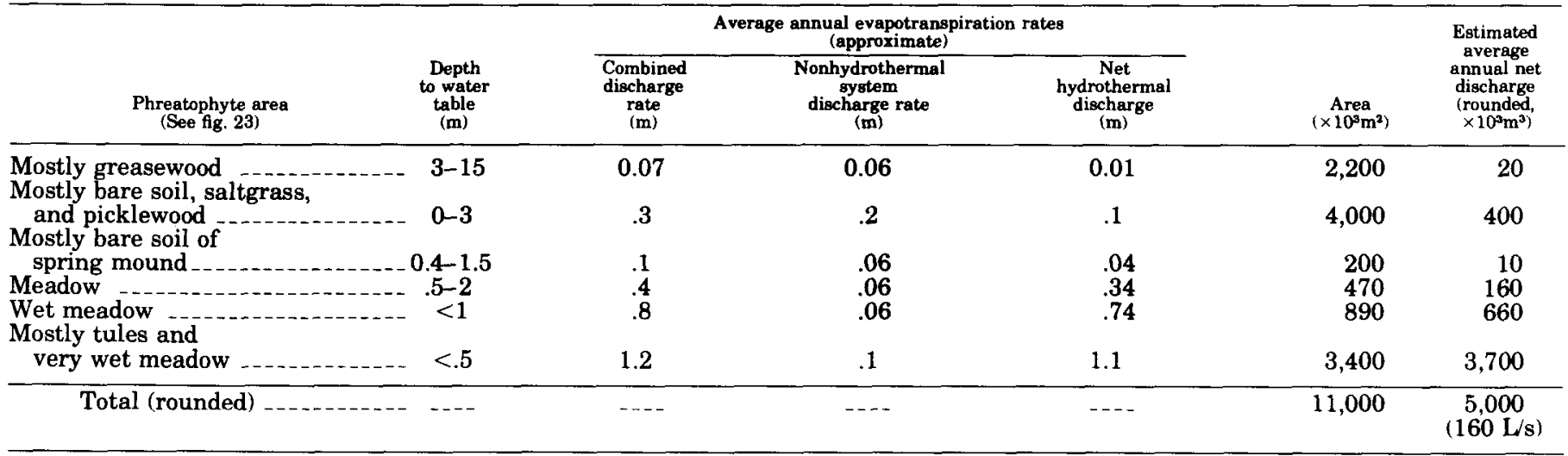




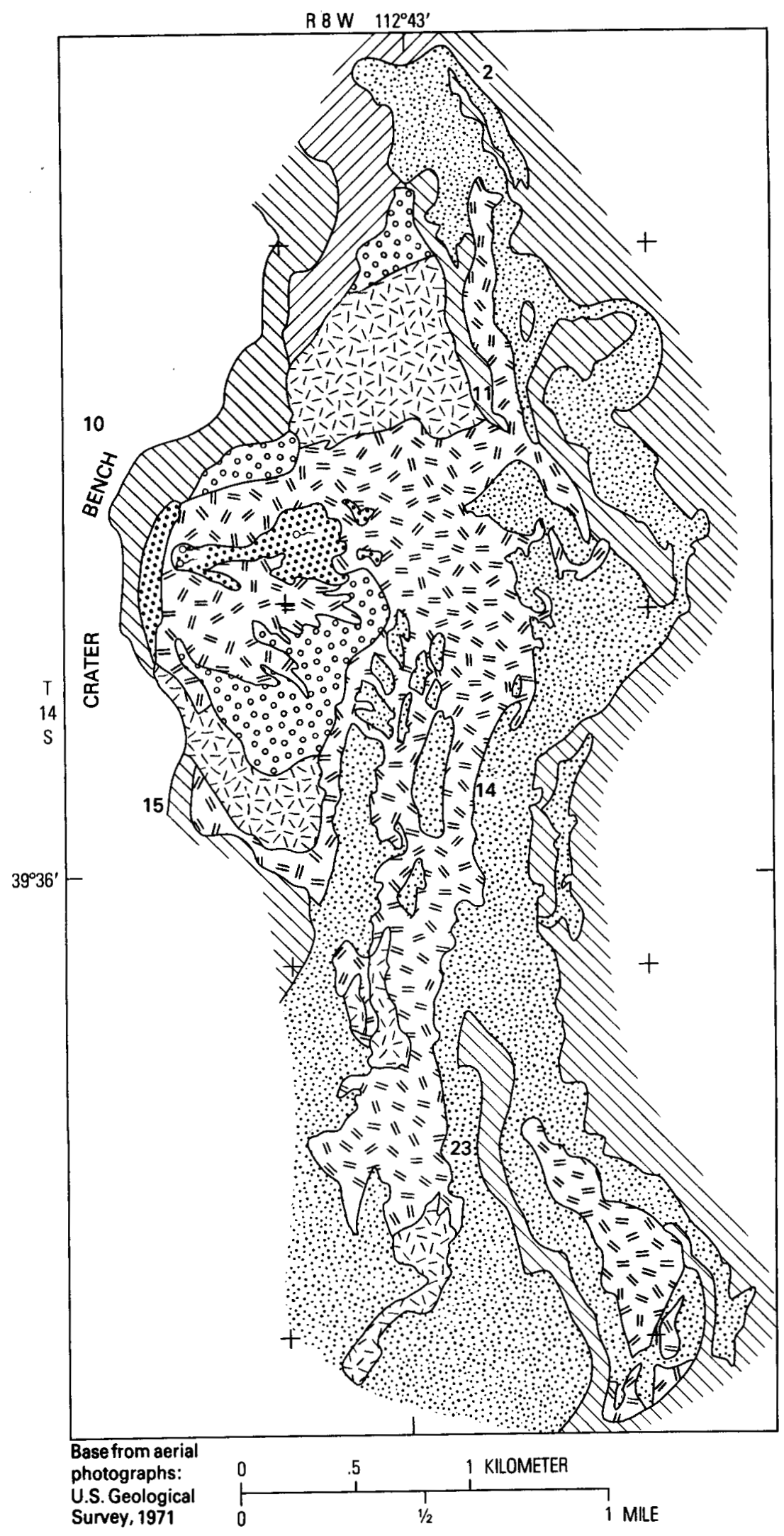

Figure 23.-Phreatophyte distribution in the Crater Hot Springs area. 


\section{DESCRIPTION OF MAP UNITS}

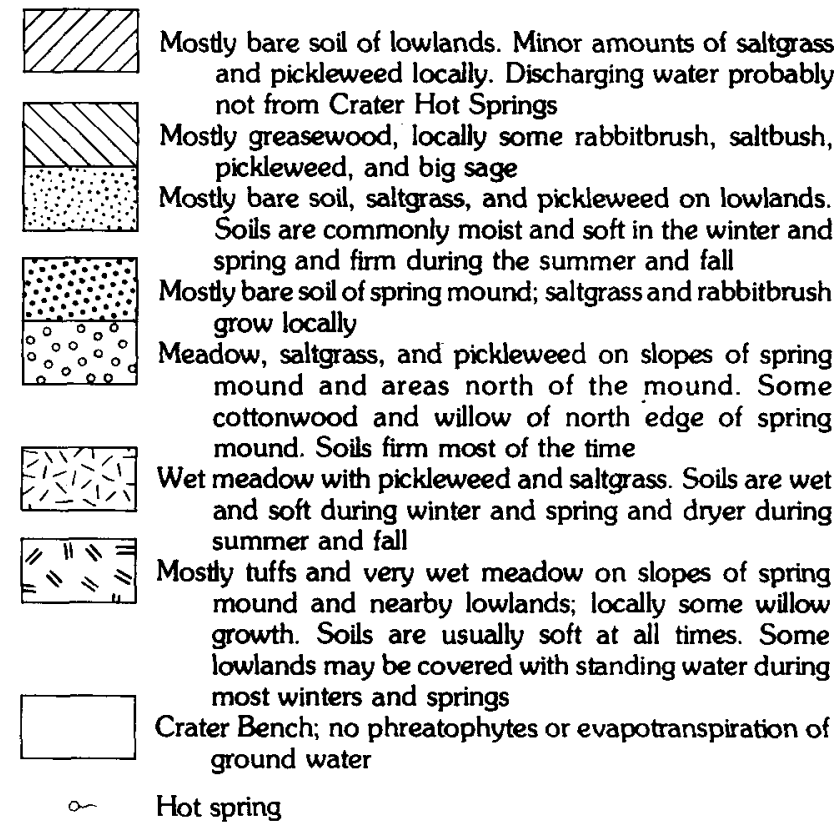

FIGURE 23.-Continued.

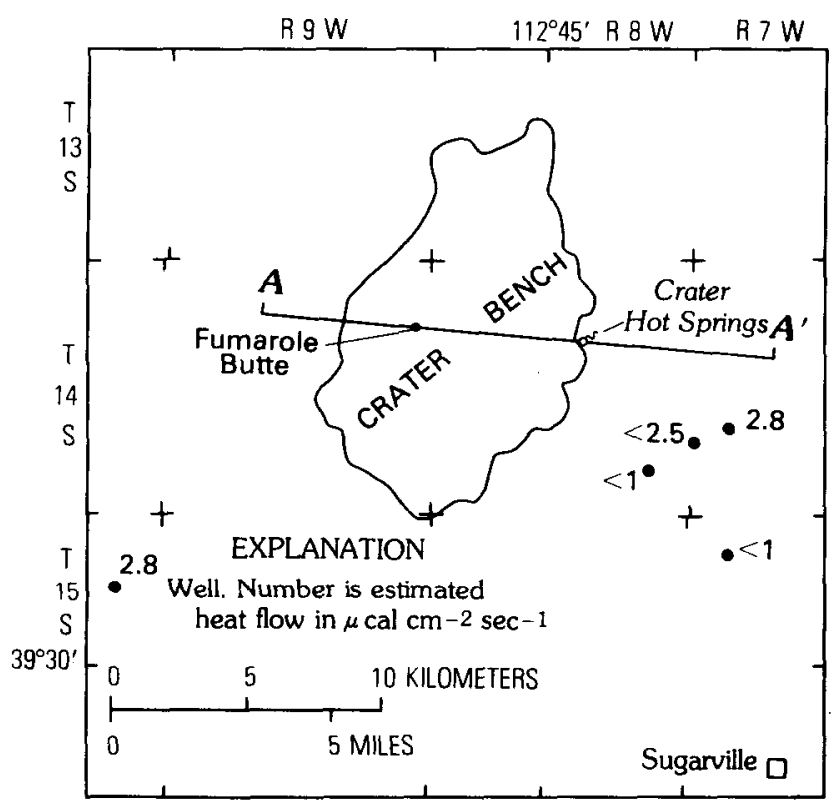

Figure 24.-Heat flow in the Crater Hot Springs area:

the mound area commonly is saturated to land surface during the winter and spring; at other times, the water table is at a depth commonly no greater than $2-3 \mathrm{~m}$. The spring mound has an area of approximately $32 \mathrm{~km}^{2}$. The net evapotranspiration rate over the mound is estimated to average on the order of $0.3 \mathrm{~m}$; therefore, the estimated evapotranspiration of mixed water is about $10 \times 10^{6} \mathrm{~m}^{3} / \mathrm{yr}$. The rate of underflow to the west and north is unknown, but is estimated to be much less than the rate of evapotranspiration. Only 40 percent of the total discharge of mixed water is convective flow from the hydrothermal reservoir or at least $4 \times 10^{6} \mathrm{~m}^{3} / \mathrm{yr}$. The heat convectively discharged by this flow of water is at least $43 \times 10^{13} \mathrm{cal} / \mathrm{yr}$; this discharge figure is based on the cooling of the convective flow of thermal water from a possible reservoir temperature of $120^{\circ} \mathrm{C}$ to an ambient land-surface temperature of $12^{\circ} \mathrm{C}$.

Figure 27 shows a melting pattern of freshly fallen snow near Hatton Hot Spring. According to White (1969), very high heat flow rates.are required to produce such melting. Subsurface temperatures as high as $70^{\circ} \mathrm{C}$ can be expected at depths of as little as $10 \mathrm{~m}$ under these snowmelt areas.

\section{VICINITY OF SALT LAKE CITY}

Geothermal resources in the Salt Lake City area probably have no potential for electric power generation, but they are discussed here because of their potential value for uses, such as space heating, associated with urban development. Two areas of hydrothermal potential have been mapped by Marine and Price (1964). Their map has been modified as a result of additional data that became available after its compilation in 1959. The modifications involved the enlargement of the hydrothermal areas, as shown on figure 28 . The map is based on discharge temperatures of wells generally drilled to depths of $200 \mathrm{~m}$ or less.

The northern and larger of two areas extends generally westward from the faults along the Wasatch Range front at least to the Great Salt Lake. The western and northern boundaries of the warm-water body are generally unknown; however, the map shows approximate southern and eastern limits. The warmest water in the northern area issues from Becks (B-1-1) $14 \mathrm{dcbS}$ and Wasatch Hot Springs (B-1-1)25dbS, $56^{\circ} \mathrm{C}$ and $42^{\circ} \mathrm{C}$, respectively. Both issue from Paleozoic limestone at the Warm Springs fault. The distribution of water temperatures suggests that most of the warm water originates from faults in the eastern part of the warmwater area, then migrates westward in the alluvium.

The hydrothermal area at the south end of Jordan Valley has similar temperatures. Crystal Hot Springs (C-4-1)11 and 12bS (fig. 28) has a reported temperature of $58^{\circ} \mathrm{C}$. It, like Becks and Wasatch Hot Springs, probably flows from a permeable fault zone. The heat in the water is probably the result of deep circulation.

The warm-water areas (fig. 28) may be enlarged to a greater extent as more data become available. The southern area might be extended farther northward into the area northwest of Sandy, and the northern area may be enlarged westward and possibly northward. 


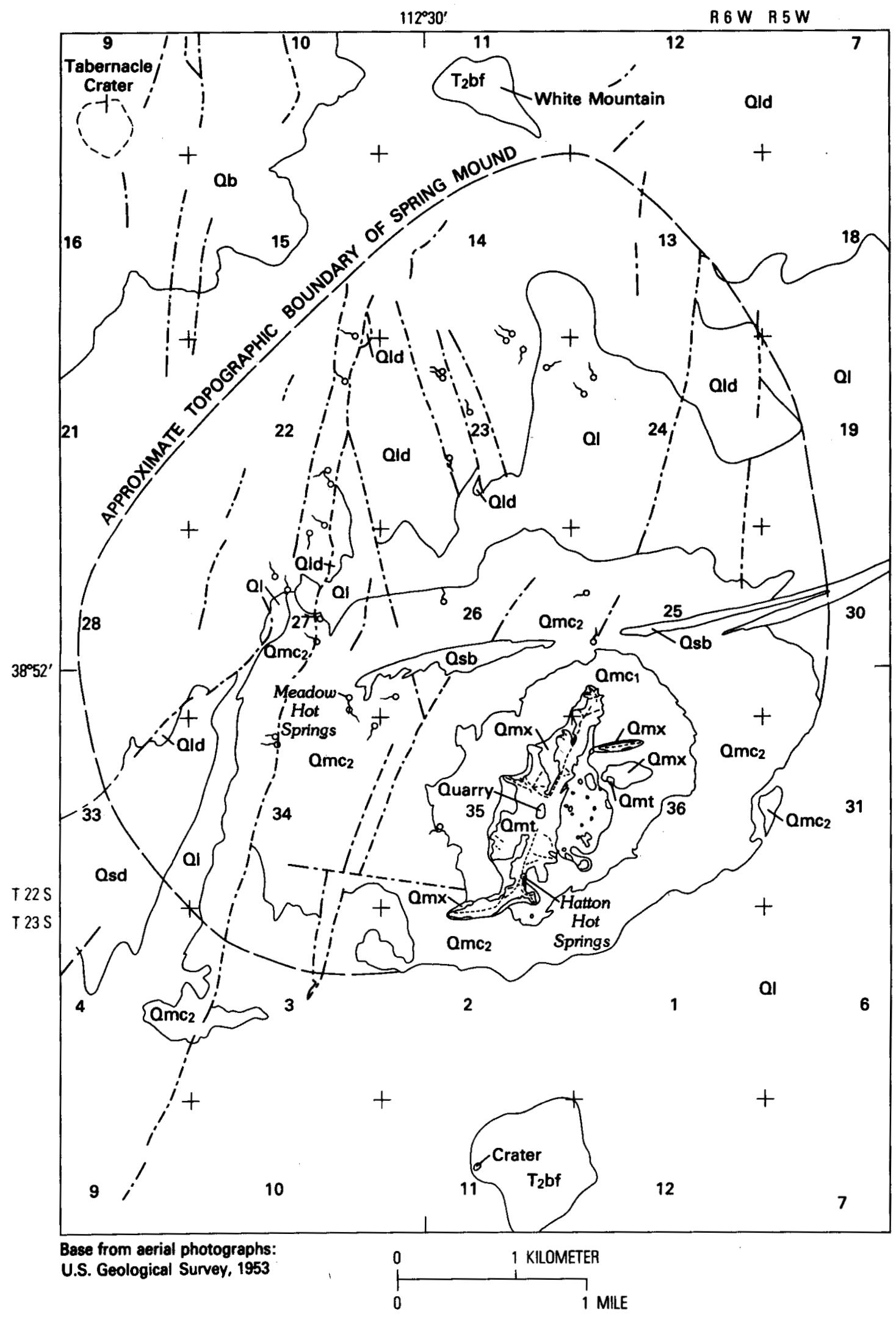

Figure 25.-Reconnaissance geologic map of the Meadow and Hatton Hot Springs area. 
CORRELATION OF MAP UNITS

\begin{tabular}{|c|c|c|c|}
\hline asd & ald & - Holocene & \multirow{7}{*}{ - QUATERNARY } \\
\hline Qsb & QI & \multirow{6}{*}{ - Pleistocene } & \\
\hline $\mathrm{Omc}_{1}$ & $\mathrm{Omc}_{2}$ & & \\
\hline Qmx & & & \\
\hline Qmt & & & \\
\hline Qb & & & \\
\hline$T_{2} b f$ & & & \\
\hline
\end{tabular}

DESCRIPTION OF MAP UNITS HYDROTHERMALLY RELATED DEPOSITS

Omt SPRING-MOUND TRAVERTINE-Highly porous to dense and banded calcium carbonate deposited during the cooling and evaporation of water discharged from the Hatton Hot Spring system. Commonly light tan, yellow or greenish gray. The mound of its crest extends $10 \mathrm{~m}$ above the adjacen valley floor

Omx SPRING-MOUND TALUS-Mostly angular fragments of travertine forming the flank of the spring mound, resulting from the disintegration of Qmt, described above. Mostly sand and gravel size; some larger blocks

Omc 1 SPRING-MOUND COLLUVIUM-Tan silty fine- to medium-grained sand. Dominantly travertine fragments carried by infrequent runoff trom the mound. Minor salt crust present in some damp low-altitude areas. Surface generally is firm. Material saturated at shallow depths with ground water, having temperatures as high as $67^{\circ} \mathrm{C}$

$\mathrm{Omc}_{2}$ SPRING-MOUND COLLUVIUM-Mostly tan to brown sandy silt and silty sand derived characteristically by disintegration and erosion of spring mound travertine. Areas to the north and west have ground-water saturation generally to within $1 \mathrm{~m}$ of the land surface resulting in a surface salt crust or grassy wet areas. Locally, some areas have dry, firm surface

VALLEY-FLOOR DEPOSITS

LAKE BONNEVILLE SEDIMENTS-Mostly medium-brown sandy silt; relatively undissected. Land surface, usually near horizontal and flat, usually damp and hard; salt crust and marsh areas common near springs and seeps. Depth to ground-water saturation generally less than $1 \mathrm{~m}$

Old DISSECTED LAKE BONNEVILLE SEDIMENTS - (See above description of $Q$ l.) Dissected by infrequent runoff. Locally includes blow sand, sand dunes, and playa silt and clay. Depth to ground-water saturation variable and dependent on topographic

Osb SAND BAR-Tan, medium- to coarse-sand and fine gravel. Mostly quartz, travertine, and volcanic-rock fragments. Bars extend about $1 \mathrm{~m}$ above the general land surface. Formed in Lake Bonneville at an altitude of about $1455 \mathrm{~m}$ above mean sea level

asd SAND DUNES-Mostly fine- to coarse-grained, silty quart sand transported mostly by southwesterly winds. Includes some dissected Lake Bonneville sediments (Q1d)

CONSOLIDATED ROCKS

\begin{tabular}{|c|c|}
\hline$a b$ & QUATERNARY BASALT-Dark gray, commonly \\
\hline $\mathrm{T}_{2} \mathrm{bf}$ & LATE TERTIARY BASALT AND BASALTIC \\
\hline
\end{tabular}

$$
\text { Contact }
$$

_ - - Lineament on aerial photographs; may be a fault

........ Ridge line on spring mound

on Spring or seep

Figure 25.-Continued.
Discovery of warm water at shallow depths elsewhere in the valley is unlikely.

Becks and Wasatch Hot Springs yield sodium chloride-type waters with fairly high concentrations of dissolved solids, $13,000-14,000 \mathrm{mg} / \mathrm{L}$ and 6,000-13,000 $\mathrm{mg} / \mathrm{L}$, respectively. Crystal Hot Springs yields water with lower dissolved-solids concentrations, in the range of $1,300-1,700 \mathrm{mg} / \mathrm{L}$. Water flowing from faults to the alluvium near the springs probably has ion concentrations similar to the springs. As this water mixes with nonthermal water in the alluvium, the mix will have chemical characteristics intermediate between water types. In the northern area, the water in the alluvium will, therefore, have dissolved solids that are highly concentrated but less concentrated than the spring flow. Water from Becks, Wasatch, and Crystal Hot Springs or from wells nearby may be useful for space heating, but development of wells in the vicinity of the springs may stop the spring flow.

\section{GREAT SALT LAKE DESERT}

Thick beds of high-porosity clay underlie the Great Salt Lake Desert of northwestern Utah (fig. 1). Such beds have an insulating quality, impeding the conductive flow of heat to land surface. As a result, geothermal gradients must be high to discharge the heat flowing upward in the earth's crust. For example, if a regional heat flow of $2 \mathrm{HFU}$ and a thermal conductivity of porous clay of $2 \times 10^{-3} \mathrm{cal} / \mathrm{cm} / \mathrm{s}^{\circ} \mathrm{C}$ are assumed to be reasonable values, the computation of the geothermal gradient would be:

$$
\mathrm{I}=\frac{\mathrm{HFU} \times 10^{2}}{\mathrm{~K}}
$$

where

I is the geothermal gradient in ${ }^{\circ} \mathrm{C} / \mathrm{km}$, HFU is heat-flow units in $\mu \mathrm{cal} / \mathrm{cm}^{2} / \mathrm{s}$, and $\mathrm{K}$ is thermal conductivity.

The calculation becomes

$$
\mathrm{I}=\frac{2 \times 10^{2}}{2}=100^{\circ} \mathrm{C} / \mathrm{km} .
$$

If surface ambient temperatures on the desert are about $10^{\circ} \mathrm{C}$, subsurface temperature at a depth of $1 \mathrm{~km}$ would be $110^{\circ} \mathrm{C}$ if the described bed of clay were also of that minimum thickness. The implication is that areas of thick clay accumulation, like the Great Salt Lake Desert, may have low-temperature geothermal potential for space heating without a near-surface source of heat or a permeable zone in which to circulate upwardflowing hot water from great depths. The temperature- 
gradient data on the Bonneville Salt Flats in the western part of the Great Salt Lake Desert, of Turk (1973) and Whelan and Petersen (1974), support a conclusion that a geothermal potential may exist in the area.

\section{OTHER AREAS}

The few geothermal areas described in this report were selected because they appear to have the highest development potential. However, other areas in western Utah may have important geothermal potential. Additional sources of geothermal data on these areas are the thermal-spring report by Mundorff (1970), computer-stored temperature data of the Water Resources Division of the U.S. Geological Survey, and other data in the files of the U.S. Geological Survey. (See table 18.) Table 18 lists temperatures and heat-flow data for nearly 100 wells and springs. It is not designed to be a comprehensive listing of such data for Utah, but rather a limited listing for widely spaced data points selected to provide information on wells and springs having mostly above-ambient temperatures.

\section{SUMMARY AND CONCLUSIONS}

1. Several publications have summarized data on hot and warm springs in Utah (Stearns, Stearns, and Waring, 1937; Waring, 1965; and Mundorff, 1970). As a result, no attempt was made to include in this report comprehensive tables of descriptions and data for ther-

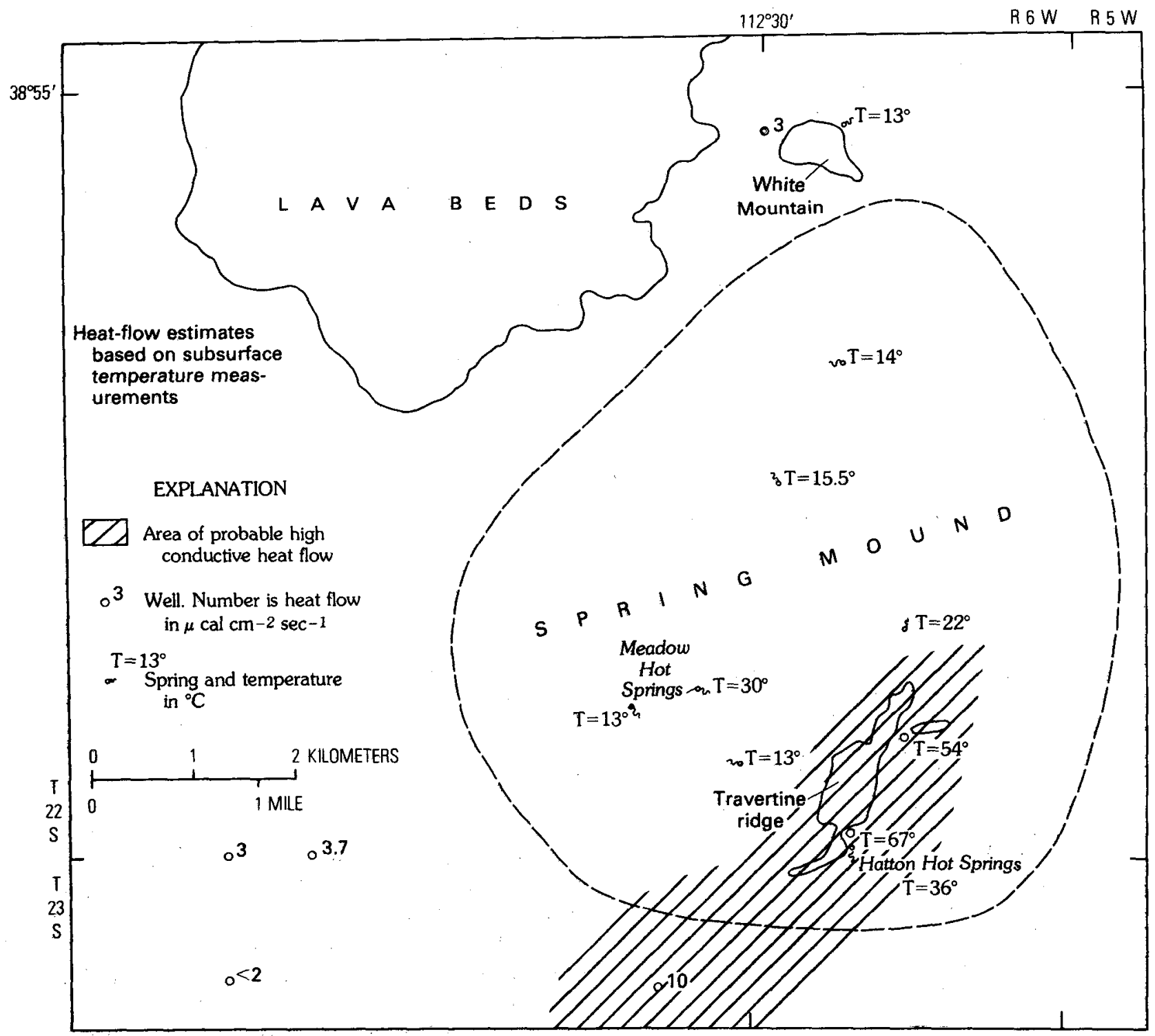

Figure 26.-Estimated heat flow and water temperatures in the Meadow and Hatton Hot Springs area. 


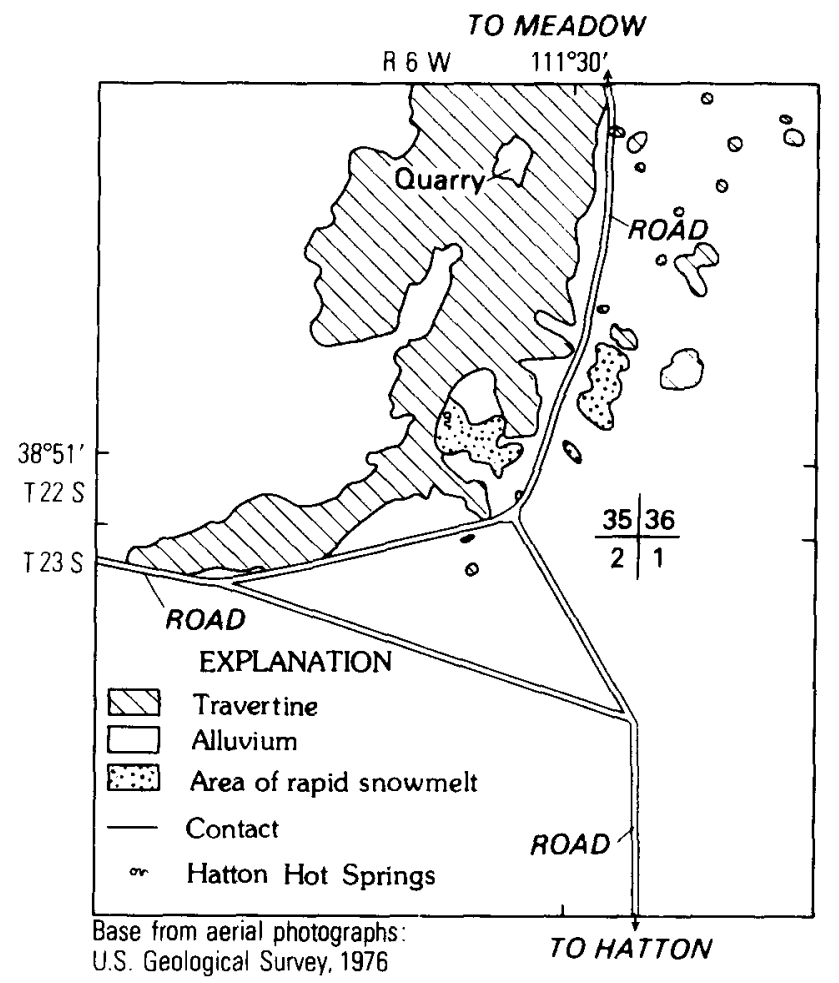

$$
\begin{aligned}
& 0+500 \text { METERS } \\
& 0 \quad 500 \quad 1000 \quad 1500 \text { FEET }
\end{aligned}
$$

FIGURE 27.-Areas of rapid snowmelt near Hatton Hot Springs, March 1976.

mal springs. However, data for selected hydrothermal systems are presented and summarized in table 15 .

2. Geologic factors are more favorable for geothermal resources in the Basin and Range province than on the Colorado Plateaus or in the Middle Rocky Mountains. The structure of the Basin and Range province is a result of sizable east-west crustal extension and crustal thinning during the last 17 million years. Igneous rocks less than 6 million years old crop out at many places, mostly in the southwestern part of Utah. Basalts as young as 10,000 years have been mapped.

3. The principal source of geothermal fluids is water stored in the hydrothermal reservoir and water entering the system as recharge from precipitation. Because of the semiarid climate of most of the area, most geothermal development for generation of electricity will remove fluids from storage at a higher rate than natural replenishment.

4. Conductive heat flows to the land surface at a generally high rate in the Basin and Range province of Utah are probably due to crustal thinning and possibly due to intrusion of young magmas into the earth's crust at shallow depths. The rates of conductive heat flow are commonly in the range of 1.5-2.5 HFU and probably average about $2.0 \mathrm{HFU}$. This is about normal for the Basin and Range province and considerably higher than the average of about $1.6 \mathrm{HFU}$ for the entire earth.

5. High-temperature convection systems may be located by searching for high-silica volcanic and intrusive rocks that are of Quaternary age. Mapping of faults, hydrothermally altered rock, and thermal-spring deposits, along with the drilling of temperature-gradient holes, would be desirable components of an exploratory program.

6. Drilling for hot, high-silica, buried bodies of rock would best be pursued in the areas of recent volcanic activity.

7. Some geothermal systems may be related to calderas because of their potential for eruption of large volumes of silicic rock. An example is the potential relation of Crater Hot Springs and Crater Bench to Thomas, Keg, and Desert calderas.

8. The southwestern part of Utah probably has the most promising geothermal potential, judged on the basis of spring temperatures, silica concentrations, and deposits such as siliceous sinter and sulfur.

\begin{tabular}{|c|c|c|c|c|c|c|c|c|c|}
\hline \multirow[b]{2}{*}{$\begin{array}{l}\text { Hydrothermal } \\
\text { system }\end{array}$} & \multicolumn{4}{|c|}{$\begin{array}{l}\text { Estimated water discharge from the hydrothermal reservoir } \\
\qquad\left(\times 10^{6} \mathrm{~m}^{3 / y r}\right)\end{array}$} & \multirow{2}{*}{$\begin{array}{c}\text { Estimated } \\
\text { total heat } \\
\text { discharge } \\
\left(\times 10^{13}\right. \\
\text { cal/yr) }\end{array}$} & \multicolumn{2}{|c|}{$\begin{array}{c}\text { Temperatures } \\
\left({ }^{\circ} \mathrm{C}\right) \\
\end{array}$} & \multirow{2}{*}{$\begin{array}{c}\text { Percent } \\
\text { thermal } \\
\text { water in } \\
\text { mixed } \\
\text { water }\end{array}$} & \multirow{2}{*}{$\begin{array}{l}\text { Estimated } \\
\text { maximum depth } \\
\text { of hydrothermal } \\
\text { reservoir below } \\
\text { land surface } \\
\text { (km) }\end{array}$} \\
\hline & $\begin{array}{l}\text { Evapo- } \\
\text { transpiration }\end{array}$ & $\begin{array}{l}\text { Spring } \\
\text { flow }\end{array}$ & $\begin{array}{l}\text { Ground-water } \\
\text { outflow }\end{array}$ & $\begin{array}{l}\text { Minimum } \\
\text { total convective } \\
\text { flow }\end{array}$ & & $\begin{array}{l}\text { Estimated } \\
\text { regervoir }\end{array}$ & $\begin{array}{c}\text { Spring } \\
\text { flow } \\
\text { maximum }\end{array}$ & & \\
\hline $\begin{array}{l}\text { Roosevelt } \\
\text { Cove Fort- }\end{array}$ & Minor & Minor & Principal & Unknown & Unknown & $260-290$ & 85 & $-\cdots$ & $6-7$ \\
\hline Sulphurdale & $-\frac{d o}{0.6}$ & $\begin{array}{c}\text { None } \\
0.02\end{array}$ & $\begin{array}{c}\text { Probably } \\
\text { small }\end{array}$ & $\frac{\text { do }}{0.6}$ & $-\frac{d o}{15}$ & $\begin{array}{c}200 \pm \\
140-200\end{array}$ & 82.5 & 40 & $\stackrel{5}{3-4}$ \\
\hline $\begin{array}{l}\text { New Castle } \\
\text { Monroe-Red Hill } \\
\text { Joseph } \\
\text { Crater } \\
\text { Meadow-Hatton }\end{array}$ & $\begin{array}{l}\text { Minor } \\
\text { Minor } \\
2.5 \\
4\end{array}$ & $\begin{array}{l}\text { None } \\
.2 \\
.02 \\
(2) \\
\text { Minor }\end{array}$ & $\begin{array}{c}0.4 \\
\text { Unknown } \\
\text { do } \\
\text { do }\end{array}$ & $\begin{array}{l}.4 \\
.2 \\
.02 \\
2.5 \\
4\end{array}$ & $\begin{array}{l}7 \\
3 \\
36 \\
43\end{array}$ & $\begin{array}{r}140-170 \\
100-160 \\
100-170 \\
110-140 \\
70-120\end{array}$ & $\begin{array}{c}107.8 \\
75 \\
65 \\
87 \\
167\end{array}$ & $\begin{array}{l}60 \\
50 \\
35 \\
50 \\
40\end{array}$ & $\begin{array}{l}3-4 \\
2-4 \\
2-4 \\
1.3-1.7 \\
-\end{array}$ \\
\hline
\end{tabular}

TABLE 15. Summary of data for selected hydrothermal systems in Utah

2Supports phreatophytes and evaporates. Included in the evapotranspiration estimate. 


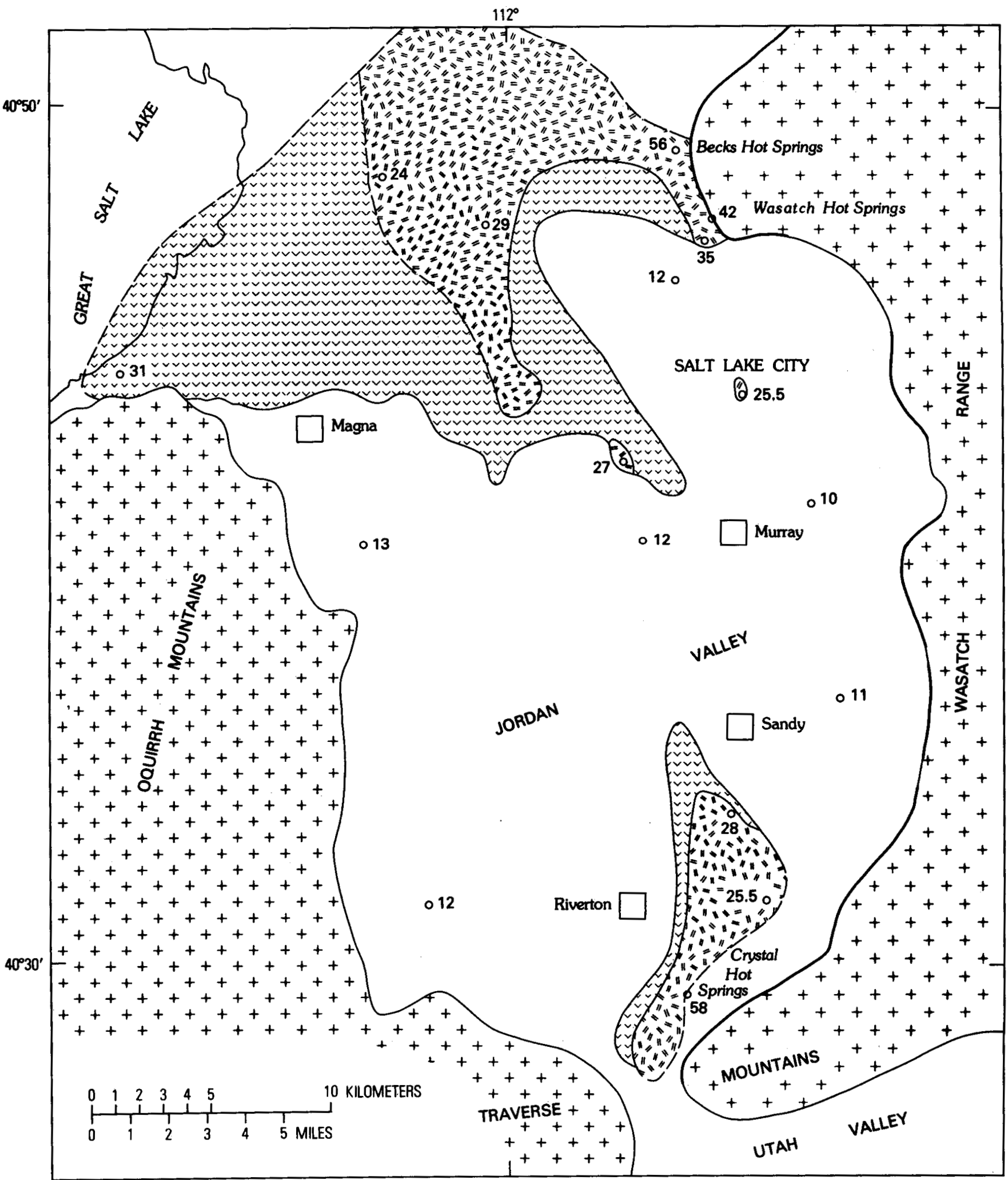

Modified from Marine and Price (1964)

Figure 28.-Areas of warm ground water in the Jordan Valley. 
9. Deep exploratory drilling near Roosevelt Hot Springs has demonstrated that this KGRA has high potential for electric power generation. Reservoir temperatures are at least $260^{\circ} \mathrm{C}$ (table 15 ), and well testing demonstrates high reservoir permeability. The reat source may be related to Pleistocene rhyolites as young as 490,000 years.

10. The Cove Fort-Sulphurdale area may have reservoir temperatures as high as $200^{\circ} \mathrm{C}$. No thermal water is known to discharge at land surface in the area, but sulfur deposits, altered ground, and gaseous emissions indicate past hydrothermal activity. Quaternary basalt flows are abundant in the area. The area extending northward $60 \mathrm{~km}$ to Neels, including Roosevelt Hot Springs and the Cove Fort-Sulphurdale KGRA's, probably has the best potential for geothermal development in Utah.

11. Thermo Hot Springs discharge from a hydrothermal system having an estimated reservoir temperature between $140^{\circ} \mathrm{C}$ and $200^{\circ} \mathrm{C}$. Estimated hot-water circulation through the hydrothermal reservoir is at a rate of $18 \mathrm{~L} / \mathrm{s}$.

12. The Newcastle area has many thermal water wells but no thermal springs. The estimated reservoir temperature for the hydrothermal system is between $140^{\circ} \mathrm{C}$ and $170^{\circ} \mathrm{C}$. An irrigation well has pumped boiling water at a rate of $108 \mathrm{~L} / \mathrm{s}$. Thermal water is discharged from a range-front fault from which it flows northward into an alluvial aquifer. The thermal water discharges its heat mostly by conduction to the land surface.

13. The Monroe-Joseph KGRA contains two hydrothermal systems, one at Joseph Hot Springs and the other at the Monroe-Red Hill Hot Springs complex. Reservoir temperatures appear to be at least $100^{\circ} \mathrm{C}$ but may be as high as $160^{\circ} \mathrm{C}-170^{\circ} \mathrm{C}$.

14. Crater, Meadow, and Hatton Hot Springs (table 15) which discharge from hydrothermal reservoirs having estimated temperatures less than $150^{\circ} \mathrm{C}$, could be

\section{EXPLANATION}

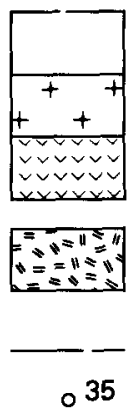

Alluvium

Consolidated rocks

Areas where ground-water temperature is commonly between $16^{\circ} \mathrm{C}$ and $21^{\circ} \mathrm{C}$

Area where ground-water temperature is commonly above $21^{\circ} \mathrm{C}$

Contact, dashed where location is indefinite

○ 35 Well; number is temperature of water in ${ }^{\circ} \mathrm{C}$

Figure 28.-Continued. considered for space and process heating. Despite their probable low reservoir temperatures, these prospects have the largest estimates of heat and water discharge of those systems listed in table 15 .

15. Areas that may have hydrothermal potential but are inadequately defined are all in the Escalante Desert northwest of Beryl and Lund and east of Table Butte.

\section{REFERENCES CITED}

Batty, J. C., Grenney, W. J., Kaliser, Bruce, Pate, A. J., and Riley, J. P., 1975, Geothermal energy and water resources in Utah, in Impacts of energy development on Utah water resources: Procedures Third Annual Conference Utah Section, American Water Resources Association, p. 223-241.

Brown, F. H., 1977, Attempt at paleomagnetic dating of opal, Roosevelt Hot Springs KGRA: University of Utah, Department of Geology and Geophysics, Technical Report 77-1, 13 p.

Crosby, G. W., 1973, Regional structure in southwestern Utah, in Geology of the Milford area 1973: Utah Geological Association Publication 3, p. 27-32.

Denton, E. H., 1976, Helium sniffer field test: Newcastle, Utah, 10-26 March 1976: U.S. Geological Survey Open-File Report 76-421, 4 p.

Erickson, M. P., 1973, Volcanic rocks of the Milford area, Beaver County, Utah, in Geology of the Milford area 1973: Utah Geological Association Publication 3, p. 13-21.

Fenneman, N. M., 1931, Physiography of western United States: New York, McGraw-Hill Book Co., 534 p.

Fournier, R. O., White, D. E., and Truesdell, A. H., 1974, Geochemical indicators of subsurface temperature-Part 1, Basic assumptions: U.S. Geological Survey Journal of Research, v. 2, no. 3, p. 259-262.

Fournier, R. O., and Rowe, J. J., 1966, Estimation of underground temperatures from silica content of water from hot springs and wet steam wells: American Journal of Science, v. 264, no. 11, p. 685-697.

Fournier, R. O., and Truesdell, A. H., 1973, An empirical Na-K-Ca geothermometer for natural waters: Geochimica et Cosmochimica Acta, v. 37, p. 1255-1275.

Galyardt, G. L., and Rush, F. E., 1979, Geology of the Crater Hot Springs KGRA and vicinity, Juab and Millard Counties, Utah: U.S. Geological Survey Open-File Report 79-1158, 1 sheet, scale $1: 24,000$.

Gilbert, G. K, 1890, Lake Bonneville: U.S. Geological Survey Monograph 1, p. 332-335.

Godwin, L. H., Haigker, L. B., Rioux, R. L., White, D. E., Muffler, L. J. P., and Wayland, R. G., 1971, Classification of public lands valuable for geothermal steam and associated geothermal resources: U.S. Geological Survey Circular 647, 18 p.

Harr, R. D., and Price, K. R., 1972, Evapotranspiration from a greasewood-cheatgrass community: Water Resources Research, v. 8, no. 5, p. 1199-1203.

Heylmun, E. B., 1966, Geothermal power potential in Utah: Utah Geological and Mineralogical Survey, Special Studies 14, 28 p.

Hintze, L. F., 1963, Geologic map of southwestern Utah: Provo, Utah, Brigham Young University map, scale 1:250,000.

Houston, C. E., 1950, Consumptive use of irrigation water by crops in Nevada: Nevada University Bulletin 185, 27 p.

Lachenbruch, A. H., and Sass, J. H., 1977, Heat flow in the United States and the thermal regime of the crust, in Heacock, J. G., ed., 
The earth's crust: Geophysical Monograph Series, v. 20, American Geophysical Union, Washington, D.C., p. 626-675.

Lee, C. H., 1912, An intensive study of the water resources of a part of Owens Valley, California: U.S. Geological Survey Water-Supply Paper 294, $135 \mathrm{p}$.

Lee, W. T., 1908, Water resources of Beaver Valley, Utah: U.S. Geological Survey Water-Supply Paper 217, 57 p.

Liese, H. C., 1957, Geology of the northern Mineral Range, Millard and Beaver Counties, Utah: Salt Lake City, Utah, University of Utah, unpublished M.S. Thesis, $88 \mathrm{p}$.

Lovering, T. S., and Goode, H. D., 1963, Measuring geothermal gradients in drill holes less than 60 feet deep, East Tintic District, Utah: U.S. Geological Survey Bulletin 1172, 48 p.

Marine, I. W., and Price, D., 1964, Geology and ground-water resources of the Jordan Valley, Utah: Utah Geological and Mineralogical Survey Water-Resources Bulletin 7, 68 p.

Milligan, J. H., Marselli, R. E., and Bagley, J. M., 1966, Mineralized springs in Utah and their effect on manageable water supplies: Utah State University, Utah Water Research Laboratory Report WG23-6, $50 \mathrm{p}$.

Mower, R. W., and Cordova, R. M., 1974, Water resources of the Milford area, Utah, with emphasis on ground water: Utah Department of Natural Resources Technical Publication 43, $106 \mathrm{p}$.

Mundorff, J. D., 1970, Major thermal springs of Utah: Utah Geological and Mineralogical Survey Water-Resources Bulletin 13,60 p.

Olmsted, F. H., Glancy, P. A., Harrill, J. R., Rush, F. E., and Van Denburgh, A. S., 1975, Preliminary hydrogeologic appraisal of selected hydrothermal systems in northern and central Nevada: U.S. Geological Survey Open-File Report 75-56, 267 p.

Parry, W. T., Berson, N. L., and Miller, C. D., 1976, Geochemistry and hydrothermal alteration at selected Utah hot springs: Utah University Department of Geology and Geophysics Final Report, v. 3, $131 \mathrm{p}$.

Petersen, C. A., 1975, Geology of the Roosevelt Hot Springs area, Beaver County, Utah: Utah Geological and Mineralogical Survey, Utah Geology, v. 2, no. 2, p. 109-116.

Renner, J. L., White, D. E., and Williams, D. L., 1975, Hydrothermal convection systems, in Assessment of geothermal resources of the United States -1975: U.S. Geological Survey Circular 726, p. $5-83$.

Robinson, T. W., 1965, Water use studies utilizing evapotranspiration tanks, in Water resources of the Humboldt River near Winnemucca, Nevada: U.S. Geological Survey Water-Supply Paper 1795, p. 83-104.

Rowley, P. D., 1978, Geologic map of the Thermo 15-minute quadrangle, Beaver and Iron Counties, Utah: U.S. Geological Survey Geologic Quadrangle Map GQ-1493, 1 sheet.

Rowley, P. D., Anderson, J. J., and Williams, P. G., 1975, A summary of Tertiary volcanic stratigraphy of the southwestern high plateaus and adjacent Great Basin, Utah: U.S. Geological Survey Bulletin 1405-B, 20 p.

Rush, F. E., 1977, Subsurface-temperature data for some wells in western Utah: U.S. Geological Survey Open-File Report 77-132, $36 \mathrm{p}$.

Sass, J. H., Lachenbruch, A. H., Munroe, R. J., Greene, G. W., and Moses, T. H., Jr., 1971, Heat-flow in the western United States: Journal of Geophysical Research, v. 76, no. 26, p. 6376-6413.

- 1976, A new heat-flow contour map of conterminous United States: U.S. Geological Survey Open-File Report 76-756, 24 p.

Sass, J. H., and Munroe, R. J., 1974, Basic heat-flow data from the United States: U.S. Geological Survey Open-File Report 74-9, 426 p.

Schmoker, J. W., 1972, Analysis of gravity and aeromagnetic data,
San Francisco Mountains and vicinity, southwestern Utah: Utah Geological and Mineralogical Survey Bulletin 98, $24 \mathrm{p}$.

Schubert, Gerald, and Anderson, O.L., 1974, The earth's thermal gradient: Physics Today, v. 27, no. 3, p. 28-34.

Shawe, D. R., 1972, Reconnaissance geology and mineral potential of Thomas, Keg, and Desert calderas, central Juab County, Utah: U.S. Geological Survey Professional Paper 800-B, p. B67-B77.

Smith, R. L., and Shaw, H. R., 1975, Igneous-related geothermal sys. tems, in Assessment of geothermal resources of the United States-1975: U.S. Geological Survey Circular 726, p. 58-83.

Smith, T. B., 1974, Gravity study of the Fumerole Butte area, Juab and Millard Counties: Salt Lake City, Utah, University of Utah, unpub. M.S. thesis, $54 \mathrm{p}$.

Stearns, N. D., Stearns, H. T., and Waring, G. A., 1937, Thermal springs in the United States: U.S. Geological Survey WaterSupply Paper 679-B, p. B59-B206.

Stephens, J. C., 1974, Hydrologic reconnaissance of the Wah Wah Valley drainage basin, Millard and Beaver Counties, Utah: Utah Department of Natural Resources Technical Publication no. 47, $53 \mathrm{p}$.

Stewart, J. H., 1971, Basin and Range structure: A system of horsts and grabens produced by deep-seated extension: Geological Society of America Bulletin, v. 82, no. 4, p. 1019-1044.

Stewart, J. H., Moore, W. J., and Zietz, Isidore, 1977, East-west patterns of Cenozoic igneous rocks, aeromagnetic anomalies, and mineral deposits, Nevada and Utah: Geological Society of America Bulletin, v. 88, no. 1, p. 67-77.

Swanberg, C. A., 1974, The application of the Na-K-Ca geothermometer to thermal areas of Utah and the Imperial Valley, California: Geothermics, v. 3, no. 2, p. 53-59.

Truesdell, A. H., and Fournier, R. O., 1977, Procedure for estimating the temperature of a hot-water component in a mixed water by using a plot of dissolved silica versus enthalpy: U.S. Geological Survey Journal of Research, v. 5, no. 1, p. 49-52.

Turk, L. J., 1973, Hydrogeology of the Bonneville Salt Flats, Utah: Utah Geological and Mineralogical Survey, Water-Resources Bulletin 19, $81 \mathrm{p}$.

U.S. Weather Bureau (no date), Normal annual and May-September precipitation for the state of Utah: Map of Utah, scale 1:500,000, 1 sheet.

Waring, G. A., [revised by R. R. Blankenship and Ray Bentall], 1965, Thermal springs of the United States and other countries of the world-A summary: U.S. Geological Survey Professional Paper $492,383 \mathrm{p}$.

Whelan, J. A., 1970, Radioactive and isotopic age determinations of Utah rocks: Utah Geological and Mineralogical Survey Bulletin $81,75 \mathrm{p}$.

Whelan, J. A., and Petersen, C. A., 1974, Bonneville Salt Flats-A possible geothermal area?: Utah Geological and Mineralogical Survey, Utah Geology, v. 1, no. 1, p. 71-82.

White, D. E., 1969, Rapid heat-flow surveying of geothermal areas, utilizing individual snowfalls as calorimeters: Journal of Geophysical Research, v. 74, no. 22, p. 5191-5201.

White, D. E., and Williams, D. L., eds., 1975, Assessment of geothermal resources of the United States-1975: U.S. Geological Survey Circular 726, $155 \mathrm{p}$.

White, W. N., 1932, A method of estimating ground-water supplies based on discharge by plants and evaporation from soil: U.S. Geological Survey Water-Supply Paper 659-A, 105 p.

Young, A. A., and Blaney, H. F., 1942, Use of water by native vegetation: California Department of Public Works, Division of Water Resources. Bulletin 50, 154 p. 
TABLES 16,17 , AND 18 
TABLE 16.-Inventory of Thermo Hot Springs ${ }^{1}$

[Flow rate: Estimated total visible flow of the orifices. Elevation: Reference to adjacent land surface (LS). Specific conductance is in $\mu \mathrm{mhos} / \mathrm{cm}$ at $25^{\circ} \mathrm{C}$. + indicates very small flows. See fig. 10 for map no.]

\begin{tabular}{|c|c|c|c|c|c|c|c|c|c|c|}
\hline \multirow[b]{2}{*}{$\begin{array}{c}\text { Map } \\
\text { no. }\end{array}$} & \multirow[b]{2}{*}{$\begin{array}{c}\text { Number } \\
\text { of } \\
\text { orifices }\end{array}$} & \multicolumn{2}{|r|}{ Flow } & \multicolumn{6}{|c|}{ Principal orifice } & \multirow[b]{2}{*}{ Remarks } \\
\hline & & $\mathbf{L} / \mathbf{s}$ & Direction & $\underset{(\mathrm{m})}{\text { Length }}$ & $\underset{(\mathrm{m})}{\text { Width }}$ & $\underset{(\mathrm{m})}{\text { Depth }}$ & $\begin{array}{c}\text { Eleva- } \\
\text { tion } \\
(\mathrm{m})\end{array}$ & $\begin{array}{l}\text { Tempera- } \\
\text { ture } \\
\left({ }^{\circ} \mathrm{C}\right)\end{array}$ & $\begin{array}{l}\text { Specific } \\
\text { conduct- } \\
\text { ance }\end{array}$ & \\
\hline \multicolumn{11}{|c|}{ West spring mound } \\
\hline \multicolumn{11}{|c|}{ Springs in south meadow area: } \\
\hline 1 & 1 & $\stackrel{+}{0.01}$ & $\begin{array}{l}\text { Southwest } \\
\text { Southwest }\end{array}$ & $\begin{array}{r}0.7 \\
.3\end{array}$ & $\begin{array}{r}0.4 \\
.3\end{array}$ & $\begin{array}{l}0.1 \\
1.0\end{array}$ & $\begin{array}{l}\text { At LS } \\
\text { At LS }\end{array}$ & $\begin{array}{l}39 \\
70\end{array}$ & 2,100 & $\begin{array}{l}\text { Southernmost spring on mound. } \\
\text { Located } 3 \mathrm{~m} \text { north-northeast of No. } 1 \text { along mound } \\
\text { axis. }\end{array}$ \\
\hline $\mathbf{3}$ & 4 & + & Southwest & .3 & .3 & .3 & At LS & 66 & $-\cdots$ & $20 \mathrm{~m}$ north of No. 2 . Sinter deposits nearby. \\
\hline 4 & 4 & + & $\begin{array}{r}\text { Southwest } \\
\text { and east }\end{array}$ & .3 & .3 & 1.0 & At LS & --- & $-\cdots$ & $\begin{array}{l}\text { North end of meadow at shoulder of mound. Sinter } \\
\text { deposits nearby. }\end{array}$ \\
\hline \multicolumn{10}{|c|}{ Springs flowing east in mostly grassy channels: } & \\
\hline 5 & 2 & + & East & .4 & .3 & .6 & At LS & 56 & $-\cdots$ & $\begin{array}{l}15 \mathrm{~m} \text { north of No. } 4 \text {. Located slightly east of mound } \\
\text { axis. Deposits of salt on surface. }\end{array}$ \\
\hline 6 & 2 & + & East & .4 & .4 & $-\cdots$ & At LS & 54 & $-\cdots$ & $\begin{array}{l}\text { Springs are oriented east-west. Only east spring sup- } \\
\text { ports grass; on east flank of mound. }\end{array}$ \\
\hline 7 & 4 & + & East & .3 & .3 & 1.7 & +0.3 & 72 & --- & $\begin{array}{l}\text { Mound is sinter, } 1.5 \mathrm{~m} \text { in diameter. Other three } \\
\text { orifices are smaller and 3-6 m northeast. }\end{array}$ \\
\hline$\stackrel{8}{8}$ & 5 & + & East & .3 & .2 & .6 & At LS & --- & --- & Water flows to and ponds on lowlands near mound. \\
\hline $\begin{array}{l}\text { Springs } \\
9\end{array}$ & & $\begin{array}{l}\text { in } p o \\
+\end{array}$ & orly develope & $\begin{array}{l}\text { d chann } \\
.3\end{array}$ & . 3 & 1.5 & At LS & 61 & --- & $\begin{array}{l}\text { At southwest edge of north-south elongated grassy } \\
\text { area. } 11 \mathrm{~m} \text { north of No. } 8 \text {. }\end{array}$ \\
\hline 10 & 4 & + & East & 4 & 3 & 6 & At LS & 70 & --- & Channel extends part way down flank. \\
\hline \multicolumn{10}{|c|}{ Springs flowing east in grassy channels to lowlands: } & \\
\hline 12 & $\mathbf{3}$ & .1 & $\begin{array}{l}\text { East } \\
\text { East }\end{array}$ & $\begin{array}{l}.0 \\
.2\end{array}$ & .0 & $\begin{array}{l}.6 \\
.3\end{array}$ & $\begin{array}{l}-.7 \\
-.8\end{array}$ & $\begin{array}{l}65 \\
74\end{array}$ & 1,900 & $\begin{array}{l}\text { Spring area has three distinct arms at mound axis. } \\
\text { Principal spring is middle spring of group. }\end{array}$ \\
\hline Spring & flowing & west: & West & .3 & .3 & ---- & -.8 & 67 & --- & $\begin{array}{l}\text { On mound axis near south edge of trail crossing } \\
\text { mound. Flow ponds on lowlands. }\end{array}$ \\
\hline \multicolumn{10}{|c|}{ Springs north of trail crossing mound: } & \\
\hline $\begin{array}{l}14 \\
15\end{array}$ & $\begin{array}{l}1 \\
1\end{array}$ & $3^{+}$ & $\begin{array}{l}\text { East } \\
\text { West }\end{array}$ & $\begin{array}{l}.3 \\
.8\end{array}$ & $\begin{array}{l}.2 \\
.7\end{array}$ & $\begin{array}{l}.1 \\
.8\end{array}$ & $\begin{array}{c}\text { At LS } \\
-.8\end{array}$ & $\begin{array}{l}66 \\
82.5\end{array}$ & --- & $\begin{array}{l}\text { At east margin of mound. } \\
\text { Located slightly west of mound axis in southern part } \\
\text { of a } 20-\mathrm{m} \text { diameter tule area. }\end{array}$ \\
\hline $\begin{array}{l}16 \\
17\end{array}$ & $\begin{array}{l}2 \\
1\end{array}$ & $\begin{array}{l}2 \\
+\end{array}$ & $\begin{array}{l}\text { East } \\
\text { East }\end{array}$ & .2 & .2 & --- & At LS & $\begin{array}{l}54 \\
61\end{array}$ & 1,650 & $\begin{array}{l}\text { At east margin of mound. } \\
\text { On east flank of mound. Farthest north of springs on } \\
\text { mound. }\end{array}$ \\
\hline
\end{tabular}

Summary of springs on west mound: Number of orifices: 54 Total visible flow: $1-2 \mathrm{~L} / \mathrm{s}$

Maximum temperature: $82.5^{\circ} \mathrm{C}$

Specific conductance range: $1,650-2,100 \mu \mathrm{mhos} / \mathrm{cm}$

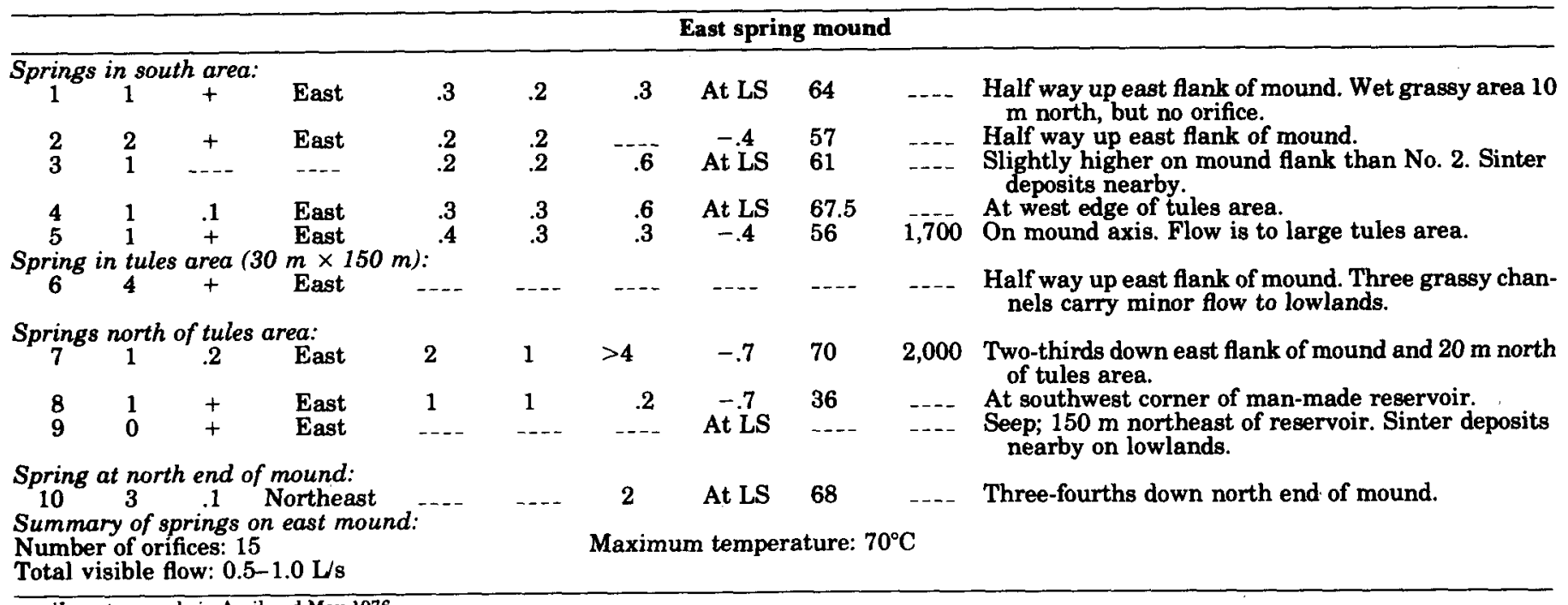

\footnotetext{
'Inventory made in April and May 1976.
} 
TABLE 17.-Inventory of Crater Hot Springs, February 1976

[Directions, distances, dimensions, and flow rates are estimated. See figure 28 for locations of larger springs. Size: Small, length and width less than 0.2 by $0.2 \mathrm{~m}$. Flow: Small, less than about $0.05 \mathrm{LS}$ ]

\begin{tabular}{|c|c|c|c|c|c|}
\hline $\begin{array}{l}\text { Pool or } \\
\text { orifice }\end{array}$ & Location & $\begin{array}{c}\text { Size } \\
\text { (length } \times \text { width } \times \\
\text { de, th; in m) }\end{array}$ & $\begin{array}{l}\text { Flow } \\
(\mathrm{L} / \mathbf{s})\end{array}$ & $\begin{array}{c}\text { Maximum } \\
\text { temper- } \\
\text { ature } \\
\left({ }^{\circ} \mathrm{C}\right)\end{array}$ & Remarks \\
\hline
\end{tabular}

\section{Main pools:}

South (S) Southwest flank of spring-mound crest $\quad$ - $32 \times 7 \times 0.3$

North (N) Northwest flank of spring-mound crest $\quad-30 \times 4 \times 1$ Along southwest ditch:

D1

D2

D3 $\ldots .15 \mathrm{~m}$ southwest of $\mathrm{D} 2 \ldots .2 \times 0.2 \times 0.1$

D4 $2 \mathrm{~m}$ southwest of D3

D5

D6

D7 _...1 m southwest of D6

D8 $-2 .-9 \mathrm{~m}$ southwest of $\mathrm{D} 7$

D9

D10 $\ldots . .50$ Southwest of fence $0.5 \times 0.5 \times 0.5$

East of main pools:

E1 $20 \mathrm{~m}$ east of main pool-south $\ldots .5 \times 5 \times 0.5$

$\mathrm{E} 2 \ldots 12 \mathrm{~m}$ northeast of $\mathrm{E} 1$

$7 \times 4 \times 0.2$

E3 . $100 \mathrm{~m}$ east of $\mathrm{E} 2$

E4 $140 \mathrm{~m}$ east southeast of main pool-

E5 _._. $90 \mathrm{~m}$ east of E4

Recycling pools east of main pools:

$\mathrm{R} 1.20 \mathrm{~m}$ southwest of $\mathrm{E} 5$

$\mathrm{R} 2 \ldots .6 \mathrm{~m}$ east of $\mathrm{R} 1$

$\mathrm{R3} \ldots \ldots$ moutheast of $\mathrm{R} 2 \ldots$

Northeast of main pools:

$\mathrm{N} 1 \quad \ldots-30 \mathrm{~m}$ east of main pool-north $\ldots \ldots \ldots .5$

N2

$\mathrm{N} 3$

$\mathrm{N} 4$

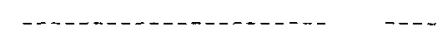

$-3 \times 4 \times 1$
Many small orifices, mostly in southeast corner of pool; undrained.

$<.158 \quad$ Drains in ditch to northeast.

$1-2$

Small $\quad 74$

Small

? $\quad \overline{80}$

77

-..-

Small $\quad \overline{6} \overline{9}$

? $\overline{84}$

Group of three orifices, 3-4 m west of ditch. Group of three orifices, $1 \mathrm{~m}$ west of ditch. $1 \mathrm{~m}$ southeast of ditch.

$11 \mathrm{~m}$ northwest of swamp.

5 orifices in ditch and many to southeast

Two orifices; temperature is of northeast orifice.

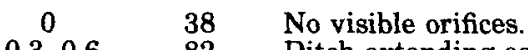

0.3-0.6 82 Ditch extending east southeast. At end of ditch, flow $=5 \mathrm{~L} / \mathrm{s}$ and temperature $=$ $65^{\circ} \mathrm{C}$.

$.3 \quad 64 \quad$ Similar orifice $2 \mathrm{~m}$ northeast.

0.87

Trenched east; flow dissipates.

$\begin{array}{cc}\text { Small } & 71 \\ 3 & 70 \\ 5 & 29\end{array}$

Swamp on south; brush on north.

Source orifice in west end of pool.

Source is surface flow from swamp. Several other recycling orifices to east.

$\begin{array}{cc}0 & 25 \\ .1 & 59 \\ \text { Small } & 77 \\ .3 & --\end{array}$

Several orifices; along ditch draining northeast from main pool-north.

$72 \quad 52$

Drains in ditch to northeast and then north toward set of buildings. Specific conductance was $5,800 \mu$ mhos.

Summary:

Observed flow:

$190 \pm \mathrm{L} / \mathrm{s}$

Observed orifices and pools:

$40 \pm 5$

Flow from seeps and the like (approximate): $245 \pm \mathrm{L} / \mathrm{s}$ Total (rounded): 
TABLE 18.-Selected subsurface temperature and heat-flow data not summarized on maps

TTemperature description: $\mathbf{M}$, maximum in well; probably bottom-hole temperature in most wells; $D$, discharge temperature of weil or \&pring. Temperature gradient: Estimated, computed from listed temperature, land-8urface ambient temperature, and well depth. Estimated heat flow: HFU, heat-flow units, in $\mu \mathrm{cal} / \mathrm{cm}^{2} / \mathrm{s}^{1}$ based on average temperature gradient and generalized thermal conductivity by lithology

\begin{tabular}{|c|c|c|c|c|c|c|}
\hline \multirow{2}{*}{$\begin{array}{l}\text { Approximate } \\
\text { well or spring } \\
\text { location }\end{array}$} & \multirow{2}{*}{$\begin{array}{l}\text { Total } \\
\text { depth } \\
\text { (m) }\end{array}$} & \multicolumn{2}{|c|}{ Temperature } & \multirow{2}{*}{$\begin{array}{c}\text { Average } \\
\text { Temperature } \\
\text { gradient } \\
{ }^{\circ} \mathrm{C} / \mathrm{km}\end{array}$} & \multirow{2}{*}{$\begin{array}{c}\text { Estimated } \\
\text { conductive } \\
\text { heat flow } \\
\text { (HFU) }\end{array}$} & \multirow{2}{*}{ Remarks } \\
\hline & & Degrees & $\begin{array}{c}\text { Descrip- } \\
\text { tion }\end{array}$ & & & \\
\hline \multicolumn{7}{|c|}{ Beaver area } \\
\hline $\begin{array}{l}(\mathrm{C}-28-7) 15 \mathrm{bb} \\
(\mathrm{C}-28-7) 31 \mathrm{ad} \\
(\mathrm{C}-29-7) 15 \mathrm{~cd} \\
(\mathrm{C}-29-8) 9 \mathrm{ba} \\
(\mathrm{C}-29-8) 31 \mathrm{ad} \\
(\mathrm{C}-29-8) 35 \mathrm{ab} \\
(\mathrm{C}-29-8) 36 \mathrm{ac} \\
(\mathrm{C}-30-7) 5 \mathrm{~cd}\end{array}$ & $\begin{array}{r}300 \\
34 \\
46 \\
46 \\
94 \\
157 \\
110 \\
245\end{array}$ & $\begin{array}{l}10 \\
11.2 \\
11.6 \\
18 \\
12.1 \\
18.5 \\
22 \\
22\end{array}$ & $\begin{array}{l}\mathrm{D} \\
\mathrm{D} \\
\mathrm{D} \\
\mathrm{D} \\
\mathrm{D} \\
\mathrm{D} \\
\mathrm{D} \\
\mathrm{D}\end{array}$ & $\begin{array}{c}\text { Very small } \\
\text { Very small } \\
\text { Very small } \\
140 \\
\text { Very small } \\
45 \\
96 \\
43\end{array}$ & $\begin{aligned}<1 \\
<1 \\
<1 \\
\\
<.6 \\
<1 \\
\\
1.3 \\
3 \\
1.3\end{aligned}$ & $\begin{array}{l}\text { Irrigation well. } \\
\text { Unused. } \\
\text { Public-supply well. } \\
\text { Stock well. } \\
\text { Irrigation well. } \\
\text { Do. } \\
\text { Do. } \\
\text { Do. }\end{array}$ \\
\hline
\end{tabular}

East of Cedar City

(C-36-7)33 $2,016 \quad \ldots \quad \ldots$ Mud temperatures were reported as

\begin{tabular}{|c|c|c|c|c|c|c|}
\hline \multicolumn{7}{|c|}{ Eastern Utah } \\
\hline $\begin{array}{l}(\mathrm{D}-5-22) 22 \mathrm{ac} \\
(\mathrm{D}-11-24) 8 \mathrm{ca} \\
(\mathrm{D}-12-21) 19 \mathrm{bdS} \\
(\mathrm{D}-22-6) 4 \mathrm{ca}\end{array}$ & $\begin{array}{c}1,311 \\
2,002 \\
---\overline{492}\end{array}$ & $\begin{array}{l}46 \\
25 \\
19.5 \\
26.5\end{array}$ & $\begin{array}{l}D \\
D \\
D \\
D\end{array}$ & $\begin{array}{r}27 \\
7 \\
-33\end{array}$ & $\begin{array}{l}1.6 \\
<1.3\end{array}$ & Surpsur (SIC) Spring. \\
\hline
\end{tabular}

Milford-Minersville area

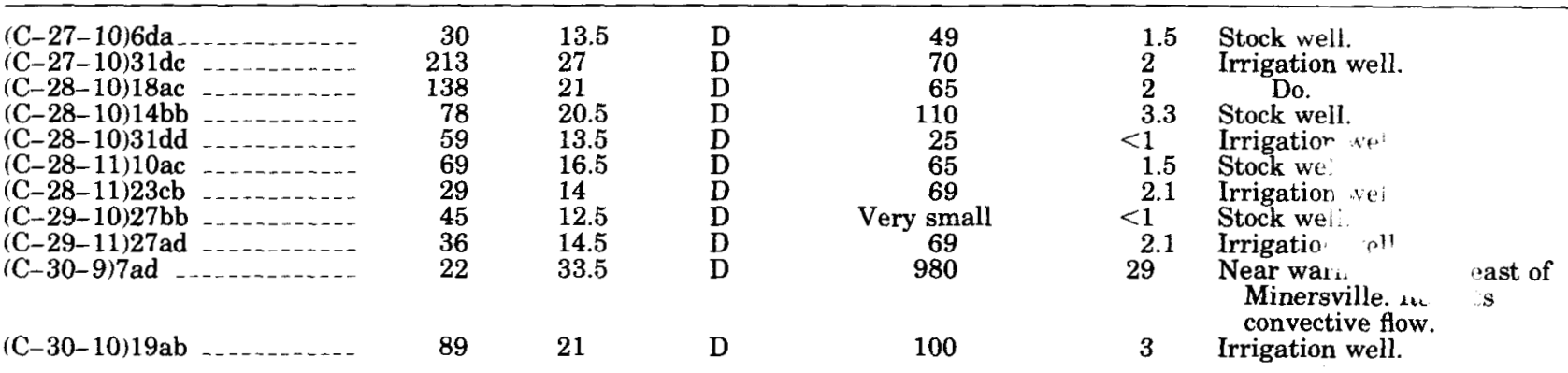

\section{Northwestern Utah}

\begin{tabular}{|c|c|c|c|c|c|c|}
\hline 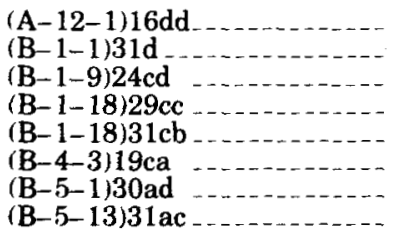 & $\begin{array}{r}74 \\
183 \\
79 \\
50 \\
70 \\
146 \\
274 \\
61\end{array}$ & $\begin{array}{l}22 \\
28.5 \\
24 \\
28 \\
24 \\
24 \\
55 \\
22\end{array}$ & $\begin{array}{l}D \\
M \\
D \\
D \\
D \\
D \\
D \\
D\end{array}$ & $\begin{array}{r}150 \\
72 \\
160\end{array}$ & $\begin{array}{r}4 \\
<2 \\
4 \\
7 \\
4 \\
3 \\
5 \\
3.6\end{array}$ & Near Salt Lake City \\
\hline $\begin{array}{l}(\mathrm{B}-6-3) 19 \mathrm{aa} \\
\text { (B-6-5)21 aaS } \\
\text { (B-7-5)15cbS } \\
\text { (B-7-5)22cdS } \\
\text { (B-8-5)5cdS } \\
\text { (B-10-6)9bbS }\end{array}$ & $\begin{array}{r}67 \\
-1- \\
-\cdots \\
-\cdots\end{array}$ & $\begin{array}{l}19 \\
21 \\
25 \\
22 \\
22 \\
22\end{array}$ & $\begin{array}{l}D \\
\mathrm{D} \\
D \\
\mathrm{D} \\
\mathrm{D} \\
\mathrm{D}\end{array}$ & $\begin{array}{c}130 \\
-\cdots- \\
-- \\
-\cdots \\
-\cdots-\end{array}$ & $\begin{array}{c}4 \\
--- \\
\cdots-- \\
\cdots-- \\
---\end{array}$ & \\
\hline$(B-10-15) 6 \mathrm{cdS}$ & $\ldots$ & 20 & $\mathrm{D}$ & 足- & - n & Warm Spring No. 2. \\
\hline (B- $11-11) 6 \mathrm{dbS}$ & $\ldots$ & 19 & D & -..- & ---- & Black Butte Spring. \\
\hline $\begin{array}{l}(\mathrm{B}-12-5) 22 \mathrm{daS} \\
(\mathrm{B}-12-6) 33 \mathrm{dbS}\end{array}$ & $\cdots$ & $\begin{array}{l}20 \\
20.5\end{array}$ & D & --- & --- & \\
\hline $\begin{array}{l}\text { B-12-6)33dbS } \\
\text { (B-13-12)30caS }\end{array}$ & $\cdots$ & 25 & D & - n & --- & \\
\hline (B-13-13)27ddS & $\ldots$ & 21 & $D$ & -..- & $-\ldots$ & \\
\hline$(\bar{B}-13-13) 34 \mathrm{cbS}$ & $\ldots$ & 21 & $\bar{D}$ & $-\ldots$ & -.-- & \\
\hline (B-13-13)35bbS $\cdots$ & $\cdots$ & 23 & $\mathbf{D}$ & $-\ldots$ & $-\ldots$ & \\
\hline $\begin{array}{l}\text { (B-13-14)21ddS } \\
\text { (B-13-14)24dcS }\end{array}$ & $-\cdots$ & $\begin{array}{ll}19.5 \\
23\end{array}$ & D & $\cdots$ & --- & \\
\hline$(B-13-16) 23 \mathrm{ccS}$ & -... & 21 & $\vec{D}$ & - & -1 & Head Spring. \\
\hline
\end{tabular}


TABLE 18.-Selected subsurface temperature and heat-flow data not summarized on maps-Continued

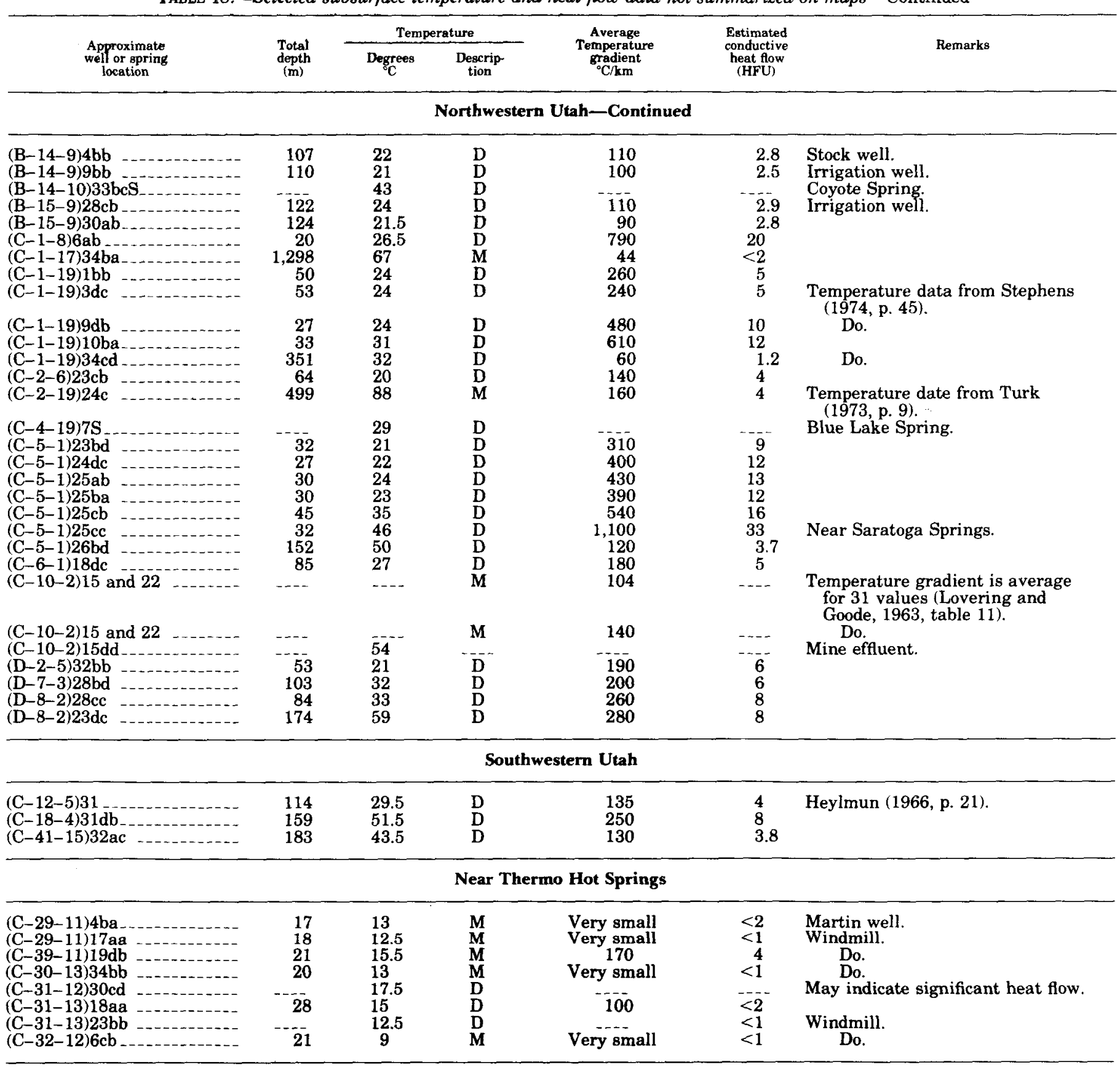

